\title{
PATRYSTYKA W CZASOPISMACH 2011 i 2012*
}

\section{DZIAŁY TEMATYCZNE}

1. Bibliografie i problemy metodologiczne

2. Prace ogólne

3. Historia wspólnot, instytucji, okresów historycznych, regionów

4. Historia doktryn (teologia)

5. Historia doktryn (filozofia)

6. Liturgia

7. Hagiografia i historia duchowości

8. Archeologia i historia sztuki

9. Biblia

9.1. Apokryfy

9.2. Gnostycyzm

10. Patrystyka i średniowiecze (łacińskie i bizantyńskie)

11. Autorzy

\section{Bibliografie i problemy metodologiczne}

André P., Bulletin de judaïsme = Bulletin de judaïsme ancien. (1), RSR 100 (2012) 105-125.

Bloise F., Contentioso fune. Note storiografiche sulla letteratura antigiudaica nel cristianesimo antico, „Auctores Nostri” 9 (2011) 171-186.

Carre P., Ouverture du colloque «L'apport des Pères de l'Église à la proposition de la foi aujourd'hui» (Paris, 27 et 28 janvier 2012), CPE 2012, nr 126, 4-5.

Catapano G., Pierre Hadot (1922-2010), „Adamantius” 17 (2011) 348-352.

Cemus R., Con l'Europa nel cuore. Ricordando il cardinale Tomás Špidlík, S.J. (17.12.1919 - 16.4.2010) nel primo anniversario della morte, OCP 77 (2011) 5-24.

Clausi B., Bibliografia della polemica nel cristianesimo antico. Un progetto, „Auctores Nostri" 9 (2011) 751-759.

De Simone A., Ricordando Marta Sordi, „Augustinianum” 51 (2011) 233-243.

Dulaey M., Bulletin d'histoire de la théologie et des idées. Patristique latine, RSR 100 (2012) 589-616.

Eckermann W., In Erinnerung an P.Dr.Dr. Adolar Zumkeller OSA (1915-2011), „Augustiniana” 61 (2011) 7-9.

Fahl D., In memoriam † Prof. Dr. theol. habil. Dr. h. c. Gottfried Hermann Goltz (1946-2010), OrtF 25 (2011) 279-284.

Fédou M., Sources Chrétiennes. Patristique et renaissance de la théologie, „Gregorianum” 92 (2011) 781-796.

* Wykaz stosowanych skrótów zob. VoxP 25 (2005) t. 48, 437-449, lub na stronie internetowej: http://www.voxpatrum.pl/pdfy/wykaz.pdf. 
Ganzer K., Rückblick auf das wissenschaftliche Oeuvre von Erwin Gatz, RQ 106 (2011) 148-154.

Hirsch-Luipold R., SAPERE (Scripta Antiquitatis Posterioris ad Ethicam Religionemque Pertinentia/Schriften der späteren Antike zu ethischen und religiösen Fragen), „Early Christianity” 2 (2011) 409-413.

Jakab A., Chronique Alexandrine VI, „Adamantius” 17 (2011) 262-296.

Jaspert B., Adalbert De Vogüé OSB (1924-2011): Erinnerungen an einen Forscher und Freund, SMon 54 (2012) 435-442.

Lang U.M., Newman and the Fathers of the Church, „New Blackfriars” 92 (2011) nr 1038, 144-156.

Marinescu A., In memoriam: Prof. Dr. Stylianos G. Papadopoulos (*1933 - † 2012), Theologe der Kirche und Träger des kirchenväterlichen Geistes und Denkens in der zeitgenössischen Welt, OrtF 26 (2012) 151-156.

Martinelli P. - Pacchioni M., Bio-bibliografia del Vescovo Luigi Padovese, „Antonianum” 86 (2011) 195-205.

Martinelli P. - Bianchi L., „In Caritate Veritas”, Luigi Padovese. Vescovo cappuccino, Vicario Apostolico dell Anatolia. Scritti in memoria, EDB, Bologna 2011, „Antonianum” 86 (2011) 207-208.

Meunier B., Bulletin de patrologie, RSPT 96 (2012) 313-351.

Sesboué B., Bulletin de théologie patristique grecque, RSR 99 (2011) 135-160.

Tilly M., Antikes Judentum und frühes Christentum 1998-2010, „,Theologische Rundschau" 77 (2012) 54-87.

Vikström B., Bengt Hägglunds traditionshermeneutik. Förmedling, förändring, förvandling, „Svensk Teologisk Kvartalskrift” 87 (2011) 98-110.

Visser A., Thirtieth Annual Erasmus Birthday Lecture: Erasmus, the Church Fathers and the Ideological Implications of Philology, „Erasmus of Rotterdam Society Yearbook" 31 (2011) 7-31.

Vollmer U., Karl Hoheisel, 16. April 1937 - 17. Februar 2011, JACh 54 (2011) 5-6.

\section{Prace ogólne}

Aguirre Monasterio R., El evangelio de Jesucristo y el Imperio Romano, EE 86 (2011) 213-240.

Alexis-Baker A., Anabaptist use of patristic literature and creeds, „The Mennonite quarterly review" 85 (2011) 477-504.

Alfeyev H., The relevance of patristic heritage in today's world, „Revista catalana de teología" 36 (2011) 21-32.

Calcagnini D., Brevi riflessioni sulle figure femminili nella produzione figurativa romana, VetCh 48 (2011) 63-79.

Castelli E., L'edizione del testo patristico greco e latino. Sguardo alla ricerca del XX secolo, VetCh 48 (2011) 81-98.

Cattani A., Diálogos, pólemos e buona discussione, „Auctores Nostri” 9 (2011) 743 749.

Cerchio B., L'ethos musicale nei Padri della Chiesa, „Archivio Teologico Torinese” 2012, nr 2, 370-388.

Chapa J., La materialidad de la palabra. Manuscritos que hablan, „Estudios Bíblicos” 69 (2011) 9-37.

Cipriani G. - Masselli G.M., „Questo matrimonio non s'ha da fare”. Attacchi di 
misoginia come protrettico alla vita beata, „Auctores Nostri” 9 (2011) 675-726.

Clausi B., La polemica nella storia del cristianesimo antico. Il cristianesimo antico nella storia della polemica, „Auctores Nostri” 9 (2011) 23-63.

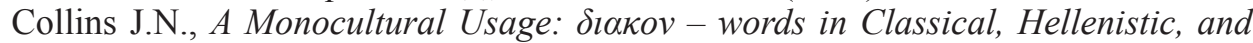
Patristic Sources, VigCh 66 (2012) 287-309.

Cook J.G., Crucifixion in the West. From Constantine to Recceswinth, ZACh 16 (2012) 226-246.

Dalmon L., Trois pièces de la „, Collectio Avellana”. Edition critique, traduction et commentaire, RechAug 36 (2011) 195-246.

Dattrino L., Padri e pastori per una nuova umanità, „Lateranum” 77 (2011) 467-482.

De Bruyn Th.S. - Dijkstra J.H.F., Greek amulets and formularies from Egypt containing Christian elements: a checklist of papyri, parchments, ostraka, and tablets, „The Bulletin of the American Society of Papyrologists” 48 (2011) 163-216.

Dell'Osso C., Cristianesimo/cristianesimi nell'antichità una prospettiva unitaria, „Augustinianum” 52 (2012) 85-104.

Engelbert P., Forschungen zur lateinischen Paläographie. Randglossen zu einem neuen Handbuch, RBen 122 (2012) 48-99.

Ferrari A., La rilettura cristiana dei miti pagani, „Antiquité Tardive” 19 (2011) 209222.

Gil Arbiol C., La pluralidad en los orígenes del cristianismo: divergencias y contrastes en las cuatro primeras generaciones, „Lumen” 60 (2011) 197-235.

Giudice H., Argumentos racionales y bíblicos sobre la pena de muerte en la patrística, TyV 52 (2011) 307-322.

Grieser H., Die antike Sklaverei aus frühchristlicher Perspektive. Eine Diskursanalyse, „Theologische Quartalschrift” 192 (2012) 2-20.

Harrison C., La escucha transformadora: la construcción del oyente en el cristianismo primitivo, „Augustinus” 56 (2011) 123-130.

Jimenez Sanchez J.A., Obispos y gladiadores: el recurso a los profesionales del anfiteatro en disputas por la eleccion episcopal, „Polis” 23 (2011) 89-113.

Kalaïtzidis P., Du „Retour aux Pères” à la nécessité d'une théologie orthodoxe moderne, „Istina » 2011, $\mathrm{nr}$ 3, 227-252.

Kischeski J., The earliest Christian war: second-and third-century martyrdom and the creation of cosmic warriors, „Journal of Religious Ethics” 39 (2011) 100-124.

Lindemann A., Kinder in der Welt der Antike als Thema gegenwärtiger Forschung, „Theologische Rundschau” 76 (2011) 82-111.

Lugaresi L., Nel teatro del mondo: un doppio sguardo su dissimulazione e rappresentazione della vita religiosa nel cristianesimo antico, „Annali di Scienze Religiose” 4 (2011) 21-68.

MacMullin E., Darwin and the other Christian tradition, „Zygon” 46 (2011) 291-316.

Mahieu V., Le meurtre rituel dans la littérature hérésiologique antique $\left(2^{e}-5^{e} \mathrm{~s}\right.$. apr. J.-C.). Analyse de la christianisation d'un topos, „Revue d'histoire ecclésiastique" 107 (2012) 801-829.

Mar M., Persecution, apology and the reflection on religious freedom and religious coercion in early Christianity, ,Zeitschrift für Religionswissenschaft” 20 (2012) 35-69.

Marin M., Appunti sulla fortuna della letteratura cristiana antica: la riscrittura cinematografica, „Auctores Nostri” 10 (2012) 11-16. 
Marin M., Letteratura polemica in età cristiana (III-V secolo), „Auctores Nostri” 9 (2011) 15-21.

Marina Saez R.M., Retorica y pensamiento en la apologetica cristiana: el „exemplum” de M. Atilio Regulo, de Tertuliano a Agustin, „Polis” 23 (2011) 153-169.

Martines C., El derecho romano y la comunidad cristiana del primer siglo, „DavarLogos” 11 (2012) 157-164.

Mersha A., Towards a Glossary of Ethiopian Manuscript Culture and Practice, „Aethiopica” 14 (2011) 145-162.

Monno O., Una "piccola valle» tra la grammatica e i testi sacri, VetCh 48 (2011) 273-283.

Neil B. - Allen P., Displaced peoples. Reflections from late Antiquity on a contemporary crisis, „Pacifica” 24 (2011) 29-42.

Olivieri L.M.M., Nota sulle matrici mediterranee dell'identità cristiana irlandese, VetCh 48 (2011) 127-137.

Prinzivalli E., Cristianesimo/cristianesimi nell'antichità, ovvero dell'attenzione alle tracce leggere, „Augustinianum” 52 (2012) 65-83.

Riedweg Ch., Nota alla tavola rotonda „,cristianesimo/cristianesimi nell'antichità”, „Augustinianum” 52 (2012) 105-106.

Rizzi M., I giovani nel cristianesimo antico tra metafora e norma, „Iuris Antiqui Historia" 4 (2012) 67-75.

Santelia S., Modelli femminili nella tarda antichità, VetCh 48 (2011) 335-357.

Shannon K., Memory, Religion and History in Nero's Great Fire: Tacitus, Annals 15.41-7, CQ 62 (2012) 749-765.

Speyer W., Zeit und Ewigkeit in den antiken Religionen und in der ältesten Reflexion, „Grazer Beiträge” 28 (2011) 1-38.

Vlantis G., Die Atheismusfrage und die ostkirchliche Patristik, „Una Sancta” 67 (2012) 125-137.

Voicu S.J., Is phôtistêrion a Constantinopolitan neologism?, „Augustinianum” 52 (2012) 339-346.

\section{Historie wspólnot, instytucji, okresów historycznych, regionów}

Alcayaga M., La formación intelectual y eclesiástica de los ministros ordenados en la Iglesia Occidental en el siglo V, TyV 52 (2011) 323-332.

Barber P.G., Christian views of military participation prior to the reign of Constantine, „Restoration Quarterly” 53 (2011) 101-112.

Bowersock G.W., Nonnosus and Byzantine diplomacy in Arabia, „Rivista Storia Italiana" 124 (2012) 282-290.

Bucci T., Le „visioni” di Costantino nelle testimonianze pagane e cristiane coeve, „Bollettino di Studi Latini” 41 (2011) 87-102.

Cooper K., Christianity, private power, and the law from Decius to Constantine: the minimalist view, JECS 19 (2011) 327-343.

Cuvillier É., Soumission et résistance. Communautés chrétiennes et pouvoir impérial au premier siècle de notre ère, „Theoforum” 42 (2011) 391-408.

Di Berardino A., Missione, conversione e diffusione del cristianesimo prima di Costantino, „Augustinianum” 52 (2012) 9-64.

Drake H.A., Intolerance, religious violence, and political legitimacy in late Antiquity, „J Journal of the American Academy of Religion” 79 (2011) 193-235. 
Freu Ch., Païens et chrétiens dans l'Empire Romain. A propos d'un ouvrage récent, LThPh 67 (2011) 589-593.

Gaumer M.A., The election of Primian of Carthage. The beginning of the end of Donatist Christianity, ZACh 16 (2012) 292-310.

Gemeinhardt P., Petrus in Rom?. Neue Diskussionen über eine alte Frage, „,Materialdienst des Konfessionskundlichen Instituts Bensheim” 62 (2011) nr 4, 63-67.

Green Th.J., Selected legislative structures in service of ecclesial reform, „The Jurist” 71 (2011) 422-449.

Guijarro Oporto S., La „primera evangelización”. Reflexiones sobre la primera misión cristiana, „Salmanticensis” 59 (2012) 193-214.

Harries J., Superfluous verbiage?: rhetoric and law in the age of Constantine and Julian, JECS 19 (2011) 345-374

Hernández G.M.F., Dos falsedades en torno al Concilio de Nicea de 325: las actas y los procedimientos verbales, „Carthaginensia” 27 (2011) 427-430.

Herrera M.M., Las vírgenes cristianas en la Iglesia primitiva, ,Toletana” 2011, nr 25, 373-437.

Humfress C., Bishops and law courts in late antiquity: how (not) to make sense of the legal evidence, JECS 19 (2011) 375-400

Kelhoffer J.A., The Search for ,, confessors” at the Council of Nicaea, JECS 19 (2011) 589-599.

Jakab A., La persécution des chrétiens dans l'Antiquité, de Néron jusqu'à Constantin le Grand. Que nous enseigne-t-elle aujourd'hui?, „Classica \& Christiana” 7 (2012) 143-156.

Lenski N., Captivity and Slavery among the Saracens in Late Antiquity (ca. 250-630), „Antiquité Tardive” 19 (2011) 237-266.

Leppin H., Christianisierungen im Römischen Reich. Überlegungen zum Begriff und zur Phasenbildung, ZACh 16 (2012) 247-278.

Magris A., Verhehlung bei den Manichäern, „Annali di Scienze Religiose” 4 (2011) 83-110.

Marasco G., L'accusa di magia e i cristiani nella tarda antichità, „Augustinianum” 51 (2011) 367-421.

Marcone A., Gli ultimi pagani di Roma, „Athenaeum” 100 (2012) 359-372.

Marrassini P., Frustula nagranitica, „Aethiopica” 14 (2011) 7-32.

Nosnitsin D., The Antiquities of Däbrä Zäyt Qaddast Maryam (East Tagray, Ethiopia), „Aethiopica” 14 (2011) 33-46.

Maraval P., Deux lettres de Constantin le Grand, CPE 2011, nr 122, 43-47.

Marone P., Le donne nel movimento donatista, „Augustinianum” 51 (2011) 85-99

Martines C., El derecho romano y la comunidad cristiana del primer siglo, „DavarLogos” 11 (2012) 157-164.

Mihálykó Á., Ein neues Zeugnis des frühen Christentums. Der Papyrus PL III/633 der Biblioteca Medicea Laurenziana, „Acta Antiqua” 51 (2011) 307-314.

Millar F., Greek and Syriac in Edessa and Osrhoene, C.E. 213-363, „Scripta Classica Israelica" 30 (2011) 93-112.

Millar F., Tyre and Berytus in the Mid-Ffth Century: Metropolitan Status and Ecclesiastical Hierarchy, „Scripta Classica Israelica” 31 (2011) 65-84.

Moorhead J., Some conflicts between Christians and Jews in the sixth century, „Studi Medievali" 52 (2011) 665-680. 
Morgenstern M., Daniel Boyarins „,Aufspaltung des Judäo-Christentums”, „Judaica” 67 (2011) 106-111.

Nedungatt G., Christian origins in India according to the Alexandrian tradition, OCP 77 (2011) 399-422.

Oliviero Niglio G.M., La diversità dei Cristiani nel carteggio tra Plinio e Traiano, „Studia et Documenta Historiae Iuris” 77 (2011) 365-384.

Oshimizu Y., La réforme administrative de Dioclétien et les cités africaines, „Antiquité Tardive" 20 (2012) 173-204.

Ramelli I.L.E., Early Christian missions from Alexandria to „,India”: institutional transformations and geographical identifications, „Augustinianum” 51 (2011) 221-231.

Rubery E., Conflict or Collusion? Pope Martin I (649-654/5) and the Exarch Olympius in Rome after the Lateran Synod of 649, StPatr 52 (2011) 339-374.

Rusch W.G., The Collatio at Carthage and the Unity of the Church, StPatr 52 (2011) 259-263.

Rydell Johnsén H., Documentation, reconstruction and deconstruction: research on female virgins and women priest in Early Christianity since 1960', SE 50 (2011) 5-34.

Sensi M., Il pellegrinaggio nella storia del cristianesimo e nella vita della Chiesa. Bilancio e prospettive, „Lateranum” 77 (2011) 659-678.

Sessa K., Ursa's return: captivity, remarriage, and the domestic authority of Roman bishops in fifth-century Italy, JECS 19 (2011) 401-432

Shandruk W.M., Christian use of magic in late antique Egypt, JECS 20 (2012) 31-57.

Shurgaia G., La riforma ecclesiastica di Vaxt'ang I Gorgasali, re di Kartli († 502), OCP 78 (2012) 393-438.

Simonetti M., La chiesa tra Diocleziano e Costantino, VetCh 49 (2012) 7-16.

Spléndido M., Apología y profecía. Los cristianos orientales frente a la crisis del gobierno de Marco Aurelio, EE 86 (2011) nr 336, 57-80.

Stathakopoulos D., Prêcher les émotions incarnées. Evêques, mediants et leurs publics dans l'Antiqué tradive, „Medievales” 61 (2011) 25-38.

Szell G., Justinian and Theodora's Peculiar Struggle with the Monophysites, „Acta Antiqua" 52 (2012) 1-8.

Thümmel H.G., Religionsgespräch im Spannungsfeld von Christentum und Heidentum, „Theologische Rundschau” 77 (2012) 241-249.

Uro R., Ritual, memory and writing in Early Christianity, ,Temenos” 47 (2011) 159-182.

Vecoli F., Communautés religieuses dans l'Égypte du IVème siècle: manichéens et cénobites, „Historia Religionum” 3 (2011) 23-46.

Villazala D.N., De „Proculi damnatione”: Próculo de Marsella y la construcción de la Iglesia gala a principios del siglo V, „Ilu” 17 (2012) 101-117.

Vives Cuesta A., Los primeros pasos del cristianismo alejandrino, EstA 46 (2011) 409-468.

Von Bruns P., ,, Kult(ur)- und Volkssprachen in der Alten Kirche”, „Forum katholische Theologie" 28 (2012) 241-250.

Wassen C., On the education of children in the Dead Sea scrolls, „Studies in Religion” 41 (2012) 350-363.

Wood J., Playing the Fame Game: Bibliography, Celebrity, and Primacy in Late Antique Spain, JECS 20 (2012) 613-640. 
Wood Ph.J., Christian authority under the early Abbasids. The „Life of Timothy of Kakushta”, POC 61 (2011) nr 4, 258-274.

Wood Ph.J., The Chorepiscopoi and controversies over orthopraxy in sixth-century Mesopotamia, JEH 63 (2012) 446-457.

\section{Historia doktryn (teologia)}

Alvarez Suárez A., Por los caminos antropológico-eclesiales de la revelación de Dios, „Teresianum” 62 (2011) 67-124.

Anapliotis A., Nikolaou, Theodor, Glaube und Forsche. Ausgewählte Studien zur Griechischen Patristik und byzantinischen Geistesgeschichte; [Rezension], OrtF 26 (2012) 220-222.

Arcari L., I monoteismi tra storia, comparazione e tipologia, „Historia Religionum” 3 (2011) 95-118.

Arnal W.E., The collection and synthesis of ,,tradition” and the second-century invention of Christianity, „Method and Theory in the Study of Religion” 23 (2011) 193-215.

Aulisa I., La concezione dei giudei come eretici tra tarda antichità e alto medioevo, VetCh 49 (2012) 39-63.

Bartolozzi G., Il concilio di Serdica e la formulazione dell'unità divina, VetCh 48 (2011) 23-38.

Bausenhart G., Freiheit-das geheime Motiv altkirchlicher Christologie, „Communio” 41 (2012) 68-79.

Boccaccini G., Jesus the Messiah: Man, Angel or God? The Jewish Roots of Early Christology, „Annali di Scienze Religiose” 4 (2011) 193-220.

Boicu D., Imago Dei - Imago Christi - Imago Augusti. O teologie politică în imagini a di-nastiei constantiniene, ,Studi Teologice” 2011, nr 1, 145-170.

Bonner G., Una última apología del pelagianismo?, „Augustinus” 56 (2011) 15-19.

Bucur B.G., ,, Early Christian binitarianism ”. From religious phenomenon to polemical insult to scholarly concept, „Modern Theology” 27 (2011) 102-120.

Brugarolas M., El Espíritu Santo, de la divinidad a la procesión: estudios de pneumatología en los Padres Capadocios, „Anuario de Historia de la Iglesia” 21 (2012) 499-502.

Carola J., Newman and the Alexandrian Fathers, „Gregorianum” 92 (2011) 828-832.

Carpin A., Sacramentalità dell'ordine, SC 57 (2012) 1-447.

Cipriani N., La función de la Iglesia en la sociedad civil: la tradición patrística, „Augustinus” 57 (2012) 295-309.

Chauvet P.L.M., La mystagogie aujourd'hui chances et limites, CPE 2012, nr 126, 65-77.

Cordovilla Pérez A., El concepto trinitario de persona, EE 87 (2012) 3-49.

Cultrera F., Cultura e teologia in Sicilia, „La Civiltà Cattolica” 162 (2011) nr 3858, 582-587.

Czachesz I., Theologische Innovation und Sozialstruktur im Urchristentum. Eine kognitive Analyse seiner Ausbreitungsdynamik, „Evangelische Theologie” 71 (2011) nr 4, 259-272.

Dagens Cl., Pourquoi et comment revaloriser la mystagogie dans la mission de l'Église?, CPE 2012, nr 126, 111-120. 
Decousou L., L'abandon de la pénitence dans la réconciliation des Ariens d'origine Barbare aux V et VI siècles, RevSR 85 (2011) 231-259.

Dîncă L., Régénération dans le baptême: le péché dit „, originel” chez les Pères grecs, „Adversus Haereses” 4 (2011) 579-587.

Dochhorn J., Der Sturz des Teufels in der Urzeit. Eine traditionsgeschichtliche Skizze zu einem Motiv frühjüdischer und frühchristlicher Theologie mit besonderer Berücksichtigung des Luzifermythos, ZThK 109 (2012) 3-47.

Du Charlat R., La parole et le corps, CPE 2012, nr 126, 121-125.

Eshleman K., Becoming heretical. Affection and ideology in recruitment to early Christianities, HTR 104 (2011) 191-216.

Essen G., Die Personidentität Jesu Christi mit dem ewigen Sohn Gottes. Dogmenhermeneutische Überlegungen zur bleibenden Geltung der altkirchlichen Konzilienchristologie, „Communio” 41 (2012) 80-103.

Fernández S., El impacto de la historia de Jesús en la sistemática de Calcedonia, TyV 52 (2011) 407-432.

Frenkel L.M., Preaching at the Council of Ephesus (431), StPatr 52 (2011) 285-283.

Gallaher B., ,, Waiting for the barbarians”. Identity and polemicism in the neo-patristic synthesis of Georges Florovsky, „Modern Theology” 27 (2011) 659-691.

Gaumer M.A., La evolución de la teología donatista como reacción al entorno cambiante en la antigüedad tardía, „Augustinus” 57 (2012) 105-136.

Giordano L., Peccato e reato nelle definizioni dell'eresia: legislazione imperiale e fondamenti biblico-patristici, „Auctores Nostri” 9 (2011) 131-142.

Giudice H., ,C Casta Meretrix”: acerca de la traducción y aplicación eclesiológica frecuente de una expresión patrística, „Teología” 107 (2012) 111-124.

Granado Bellido C., El Concilio de Nicea, „Facies Domini” 3 (2011) 401-444.

Graumann Th., Upstanding Donatists. Symbolic communication at the Conference of Carthago (411), ZACh 15 (2011) 329-355.

Grossi V., La discussione su ,cattolica-cattolico” nelle tre sedute della Conlatio Carthaginensis del 411, „Augustinianum” 51 (2011) 101-122.

Hays Ch.M., Resumptions of radicalism. Christian wealth ethics in the second and third centuries, ZNW 102 (2011) 261-282.

Hiéromoine Élisée., Cosmologie et christologie à Antioche et Alexandrie, POC 61 (2011) 6-33.

King K.L., Factions, variety, diversity, multiplicity. Representing early Christian differences for the $21^{\text {st }}$ century, ,Method and Theory in the Study of Religion” 23 (2011) 216-237.

Koscheski J., The earliest Christian war. Second-and third-century martyrdom and the creation of cosmic warriors, ,Journal of Religious Ethics” 39 (2011) 100-124.

Latham J.A., From Literal to Spiritual Soldiers of Christ: Disputed Episcopal Elections and the Advent of Christian Processions in Late Antique Rome, ChH 81 (2012) 298-327.

Leal J., Eipńvฑ/pax: el saludo entre los primeros cristianos, „Theologica” 47 (2012) 473-496.

Lien-yueh Wei S., Doctrinalizing Dreams: Patristic Views of Divine-Inspired Dreams and their Relation to the Doctrine of God and Christology, StPatr 50 (2011) 73-86.

Ludlow M., Demons, Evil, and Liminality in Cappadocian Theology, JECS 20 (2012) 179-211. 
MacLaughlin R.P., Evidencing the Eschaton. Progressive-transformative animal welfare in the Church Fathers, „Modern Theology” 27 (2011) 121-146.

Marcus J., A Jewish-Christian ," Amidah?”, „Early Christianity” 3 (2012) 215-225.

Marcu M.L., The feast of the Dormition of the Theotokos: a synthesis of the Ancient Traditions of the Virgin Mary's Dormition, „Studi Teologice” 2011, nr 1, 35-54.

Matter M., Le „, Code Théodosien”, de Constantin à Théodose II (312-450), RHPR 91 (2011) 199-224.

McIntosh Mark., The maker's meaning. Divine ideas and salvation, „Modern theology" 28 (2012) 365-384.

McLeod F.G., The significance of Constantinople II's alteration of Chalcedon's formula about Christ's natures ,,coinciding in one prosôpon”, ITQ 77 (2012) 365-383.

Meesters A.C., The Cappadocians and their trinitarian conceptions of God, „Neue Zeitschrift für systematische Theologie und Religionsphilosophie" 54 (2012) 396-413.

Mellet L., Richesses et promesses de la mystagogie pour la catéchèse à tous les âges de la vie, CPE 2012, nr 126, 102-110.

Molnar P.D., Was Barth a pro-Nicene theologian?. Reflections on „Nicaea and its legacy”, SJT 64 (2011) 347-359.

Moss C.R., Heavenly healing. Eschatological cleansing and the resurrection of the dead in the early Church, ,American Academy of Religion: Journal of the American Academy of Religion" 79 (2011) 991-1017.

Mota Felix E.R., A controvérsia sobre a divindade do Espírito Santo no século IV (d.C.), ,Revista de Cultura Teológica”, 20 (2011) nr 80, 111-118.

Neri M., Per la storia del lemma sacramentum: dall'origine pagana alla risemantizzazione cristiana, VetCh 48 (2011) 285-304.

Paciorek P.M., La hermenéutica antropológica en la teología patrística, „Augustinus” 56 (2011) 165-173.

Pansard M., Réflexions actuelles sur la mystagogie, CPE 2012, nr 126, 100-101.

Papadakis A., Beyond the „Filioque” divide. The late thirteenth century revisited, VTQ 55 (2011) 141-163.

Pasquet C., La relation typologique Ève-Marie dans la tradition syriaque, CPE 2011, nr 121, 27-41.

Patout Burns J., La santidad de la Iglesia en la teología norteafricana, „Augustinus” 56 (2011) 21-38.

Petzel P., Vom Sinn für christlich-jüdische ,, Unschärferelationen”. Zu Daniel Boyarins „,Border lines”, „Zeitschrift für katholische Theologie” 134 (2012) 22-39.

Poirier P.H., Les forces du bien et du mal dans les premiers siècles de l'Église, LThPh 68 (2012) 237-252.

Pons L.V., Implicancias teológicas y místicas de la noción de viđè en el episodio de la Samaritana, TyV 52 (2011) 153-166.

Rivas Rebaque F., Teología política en el cristianismo primitivo, EE 86 (2011) 241-266.

Roche H.L., Les trente ans de CPE, CPE 2012, nr 126, 6-9.

Rüpke J., Starting sacrifice in the beyond. Flavian innovations in the concept of priesthood and their repercussions in the treatise ,, To the Hebrews”, RHR 229 (2012) 5-30.

Sanz Valdivieso R., Creer y pensar según los Padres de la Iglesia, „Carthaginensia” 27 (2011) 275-315. 
Schnabel E., The meaning of ,,baptizein” in Greek, Jewish, and Patristic literature, „Filología Neotestamentaria” 24 (2011) 3-40.

Schneider R., "Voyez comme ils s'aiment»: le souci des pauvres: dans la théologie et la pratique de l'Église ancienne, CPE 2012, nr 127, 2-4.

Schwartz D., Religious violence and eschatology in the „Syriac Julian Romance”, JECS 19 (2011) 565-587.

Senn F.C., Everett Ferguson's Baptism in the Early Church: A Liturgical Appraisal, JECS 20 (2012) 439-455.

Sesboüe B., Les ,, incompréhensions” de Marie. „Christus” 2011, nr 229, 59-70.

Sidarouss F., Éléments d'anthropologie copte, POC 61 (2011) nr 2, 45-59.

Siniakov A.P., La mystagogie dans l'Église orthodoxe aujourd'hui, CPE 2012, nr 126, 91-99.

Smith M.S., A „Robber's Den”? A Fresh Look at the Second Council of Ephesus, AD 449, StPatr 52 (2011) 295-304.

Smith Seymour C., An exploration of early Christian communities as ,scholastic communities”, „Tyndale Bulletin” 63 (2012) 149-152.

Spataro R., Scienze patristiche e , historia ecclesiastica” per una teologia della storia, „PATH” 11 (2012) 225-233.

Stenström H., Metamorfoser, „Norsk Teologisk Tidsskrift” 112 (2011) 52-59.

Stowers S.K., The concept of ,community” and the history of early Christianity, „Method and Theory in the Study of Religion" 23 (2011) 238-256.

Tuckett Ch.M., Tobit 12, 8 and 2 Clement 16, 4, EThL 88 (2012) 129-144.

Uro R., Kognitive Ritualtheorien. Neue Modelle für die Analyse urchristlicher Sakramente, „Evangelische Theologie” 71 (2011) nr 4, 272-288.

Vannier M.A., La place et le sens de la mystagogie chez les Pères et l'enjeu actuel, CPE 2012, nr 126, 10-23.

Vannier M.A., Réflexions autour du Concile d'Éphèse, CPE 2011, nr 121, 2-7.

Vogel M., Theologien des Kreuzes, ThL 136 (2011) 723-738.

Wehr K., Virginity, singleness and celibacy. Late fourth-century and recent Evangelical visions of unmarried Christians, ,Theology and sexuality” 17 (2011) 75-99.

Wenz G., Zwei Willen und Energien in einer Person. Formierungsprobleme des christologischen Dogmas der Alten Kirche im Kontext byzantinischer Reichsgeschichte, „Homiletisch-liturgisches Korrespondenzblatt” 28 (2011) nr 105, 244-266.

Williams D.H., A catechetical address on the Nicene creed?, HTR 104 (2011) 217232.

Williams D.H., More Nicene than Nestorian: Ancient Theology in the Church of the East, StPatr 52 (2011) 319-325.

Williams G.J., Penal substitutionary atonement in the Church Fathers, „The Evangelical Quarterly" 83 (2011) 195-216.

Young F., God's Image: The „Elephant in the Room” in the Fourth Century?, StPatr 50 (2011) 57-71.

Zecher J.L., Death and the Possibility of a Ladder, StPatr 52 (2011) 327-338.

Zorbas K., Christian approach of the poverty: biblical, patristic and ethical approach, „Rivista Lasalliana” 78 (2011) 211-216. 


\section{Historia doktryn (filozofia)}

Becker M., Der schlechtere Weg ist das Ziel. Zum Leitbild des Philosophen in den Biographien des Eunapios, ZACh 15 (2011) 450-475.

Cary Ph., Philosophical and religious origins of the private inner self, „Zygon” 46 (2011) 121-134.

Castillo P.G., Cristianismo y Platonismo. Seducción y rechazo, „Naturaleza y gracia” 2012, nr 3, 451-480.

Castro J.A., Plotino. Uma estética do inefável, „Theologica” 47 (2012) 509-520.

Del Campo Echevarría A., La indagación filosófica Bizantina Acerca de los Universales, „Erytheia” 33 (2012) 57-86.

Essen G., Hellenisierung des Christentums?. Zur Problematik und Überwindung einer polarisierenden Deutungsfigur, ThPh 87 (2012) 1-17.

Fortier S., Ammonius on universals and abstraction. An interpretation and translation of Ammonius' ,'In Porphyrii Isagogen” 39, 8-42, 16, LThPh 68 (2012) 21-33.

Haynes D., The Metaphysics of Christian Ethics: Radical Orthodoxy and Theosis, „The Heytrop Journal” 52 (2011) 659-671.

Jensen R.M., Material and Documentary Evidence for the Practice of Early Christian Baptism, JECS 20 (2012) 371-405.

Kraye J., Twenty-third Annual Margaret Mann Phillips Lecture: Pagan Philosophy and Patristics in Erasmus and his Contemporaries, „Erasmus of Rotterdam Society Yearbook" 31 (2011) 33-60.

Löhr H., Abendmahl und Ethik im frühesten Christentum bis auf Justin. Zugleich zu einer topographischen Analyse und Darstellung einer materialen frühchristlichen Ethik, „Early Christianity” 3 (2012) 5-32.

Markschies Ch., Does it make sense to speak about a „Hellenization of Christianity” in Antiquity?, „Church History and Religious Culture” 92 (2012) 5-34.

Martínez García J.A., La Virtud y la construcción del personalismo: la aportación de la filosofía helenística: Cicerón, Filón de Alejandría y Plotino, „Facies Domini” 3 (2011) 445-464.

Schneider J.P., Les définitions de la philosophie dans l'Antiquité tardive. Ammonios. Commentaire sur l'Isagoge de Porphyre, 1, 11 - 9, 24 (Busse), ,Revue de théologie et de philosophie" 144 (2012) 1-28.

Wacht M., Meléte thanátou - Meditatio mortis. Zur Wirkungsgeschichte einer platonischen Bestimmung der Philosophie, JACh 54 (2011) 7-40.

\section{Liturgia}

Arocena F.M., El Himnario del Oficio Hispano, ScT 44 (2012) 9-44.

Beasoain de Paulorena J.A.G., La Eucaristía en los Santos Padres, „Scriptorium Victoriense" 59 (2012) 377-406.

Brock S.P. - Sims-Williams N., An early fragment from the East Syriac baptismal service from Turfan, OCP 77 (2011) 81-92.

Brock S.P., The Earliest Texts of the Syrian Orthodox Marriage Rite, OCP 78 (2012) 335-392.

Celi F., L'Eucharistie des origines: datation et déroulement, à la lumière des sources syriaques, RHE 106 (2011) 9-36.

Di Berardino A., Christian liturgical time and torture, „Augustinianum” 51 (2011) 191-220. 
DiCicco C., Liturgie e culture tra l'età di Gregorio Magno e Leone III, „Rivista Liturgica" 99 (2012) 576-581.

Giraudo C., The genesis of the anaphoral institution narrative in the light of the Anaphora of Addai and Mari. Between form criticism and comparative liturgy, OCP 78 (2012) 15-27.

Ivorra Robla A.V., Comentarios a las lecturas „,cotidianas” hispano-mozárabes (3), „Liturgia y Espiritualidad” 42 (2011) 292-300.

Ivorra Robla A.V., La interacción entre voz y canto en la misa hispano-mozárabe, „Liturgia y Espiritualidad” 42 (2011) 173-179.

Ivorra Robla A.V., Las doxologías de la misa hispano-mozárabe. Notas fundamentales, ,Toletana” 2011, nr 24, 309-334.

Ivorra Robla A.V., Las reliquias de los santos en el contexto de la liturgia hispanomozárabe, „Liturgia y Espiritualidad” 43 (2012) 349-362.

Jacob A., La prière pour les troupeaux de l'Euchologe Barberini. Quelques remarques sur le texte et son histoire, OCP 77 (2011) 471-486.

Metzger M., La révision de l'antique bénédiction des vierges, RevSR 86 (2012) 37-50.

Praß1 F.K., Die Psalmenauslegung der Kirchenväter im Lichte des gregorianischen Chorals am Beispiel des Weihnachtsfestes, „Heiliger Dienst” 66 (2012) 34-44.

Ray W.D., The Barcelona Papyrus and the early Egyptian eucharistic prayer, StLit 41 (2011) 211-229.

Smyth M., La prière eucharistique aux origines de la christologie: du rite à la foi?, RevSR 86 (2012) 25-35.

Suciu A., A propos de la datation du manuscrit contenant le Grand Euchologe du Monastère Blanc, VigCh 65 (2011) 189-198.

Taft R.F., Eucharistic concelebration revisited. Problems of history, practice, and theology in East and West (part 2), OCP 77 (2011) 25-80.

Tedeschi F., La „, Traditio Evangeliorum” nel catecumenato antico: un rito per la nuova evangelizzazione?, „Revista Catalana de Teología” 37 (2012) 657-683.

Vassiliadis P., From the Pauline collection to „Phos Hilaron” of Cappadocia, VTQ 56 (2012) 5-16.

Zanetti U., Deux prières de la fraction de la liturgie de Grégoire, en grec et en copte, OCP 78 (2012) 291-333

\section{Hagiografia i historia duchowości}

Andreani L., La „Vita” di san Severo „presbiter in provincia Valeriae” (BHL 7684z), „Hagiographica” 18 (2011) 197-216.

Andrei O., Cronache e monachesimi, „Adamantius” 17 (2011) 39-36.

Aulisa I., Continuità e trasformazione della leggenda di fondazione del santuario di san Michele sul monte Tumba: il caso di François Feuardent, VetCh 48 (2011) 207-224.

Azzone P., Sin of sadness. ,, acedia vel tristitia” between sociocultural conditionings and psychological dynamics of negative emotions, „Journal of psychology and christianity" 31 (2012) 16-30.

Barbu L., Natural and Fallen Will and their Twist in the Eastern Orthodox Practice of Ascetic Obedience, StPatr 50 (2011) 259-268.

Barbu L., The Bishop as Spiritual Father in Early Christian Writings and the Eastern Orthodox Tradition of Spiritual Fatherhood, StPatr 52 (2011) 27-33. 
Biffi N., L'esilio di Domitilla, „Classica \& Christiana” 7 (2012) 29-42.

Blackwood J.W., Elements of a methodical understanding of Eastern Christian mysticism, ITQ 76 (2011) 339-356.

Brock S.P., Some Paths to Perfection in the Syriac Fathers, StPatr 51 (2011) 77-94.

Brower Latz A. - Serafim Aldea Fr., Sight and Perception: The Male Gaze and the Desert Fathers, StPatr 52 (2011) 9-18.

Cățoi M.O., Despre localizarea mănăstirii Halmyrissos din „,Vita Sancti Hypatii”, „Studi Teologice” 2011, nr 3, 91-126.

Cerezo M.M., El monacato femenino (I), „Liturgia y Espiritualidad” 43 (2012) 291300.

Chronopoulos T., The Date and Place of Composition of the „Passion of St Katherine of Alexandria" (BHL 1663), AnBol 130 (2012) 40-88.

Cioffari G., San Nicolás. El obispo ideal en el pensamiento de Tomás de Aquino, „Ciencia Tomista” 139 (2012) 287-316.

D’Ayala Valva L., „Dans le miroir des Écritures”. La Bible dans l'expérience spirituelle des Pères du désert, POC 61 (2011) nr, 4, 229-257.

De Santis P., Aedificare, novare, sacrare. Luoghi di culto martiriali nelle iscrizioni di committenza episcopale, VetCh 48 (2011) 225-242.

Dehandschutter B., On the Way to Perfection: „Lust” as a Factor in Early Christian Anthropology. With an Outlook on the Syrian Fathers, StPatr 51 (2011) 95-111.

Dolbeau F., Catalogues de manuscrits latins. Inventaire hagiographique (Vingtneuvième série), AnBol 130 (2012) 395-457.

Dolbeau F., Nouvelles recherches sur les manuscrits des anciens Bollandistes, AnBol 129 (2011) 395-457.

Fellmeth U. - Lariche M. - Lenkaityte M., Circonstances des voyages des premiers pèlerins chrétiens d'Europe cccidentale en Terre Sainte, CPE 2011, nr 122, 3-25.

Girardi M., Dinamiche multietniche ed interreligiose sul limes danubiano nel IV secolo: il martirio di Saba il Goto, „Classica \& Christiana” 7 (2012) 117-142.

Godding R., Italia hagiographica (VIII): Chronique d'hagiographie italienne, AnBol 129 (2011) 175-210.

Goullet M., Conversion et passion d'Afra d'Augsbourg. Réouverture du dossier et édition synoptique des versions longue et brève, RBen 121 (2011) 94-146.

Goullet M., Conversion et passion d'Afra d'Augsbourg. Réouverture du dossier et édition synoptique des versions longue et brève, RBen 121 (2011) 94-146.

Goullet M., Expertise des textes hagiographiques mérovingiens dans leurs plus anciennes versions manuscrites: Présentation d'un projet de recherche collectif, „Hagiographica” 18 (2011) 67-88.

Iannello F., Le origini «Patriciano-Apostoliche» del monachesimo Irlandese altomedievale (secoli V-VII), SMon 53 (2011) 283-316.

Isaïa M.C., Histoire et hagiographie de saint Just, évêque de Lyon, „Hagiographica” 198 (2012) 1-30.

Izquierdo Gil P., Santa María en la historia de la santidad cristiana, EphMar 61 (2011) 11-32.

Kahn Herrick S., The Interdependent «Vitae» of Apostolic Saints, „Hagiographica” 198 (2012) 31-56.

Lampadaridi A., L'histoire de saint Porphyre de Gaza de la „Vita” aux notices du ,,Synax. CP”, AnBol 129 (2011) 241-246. 
Lanéry C., La tradition manuscrite de la „Passio Sebastiani” (Arnobe le Jeune, BHL 7543), „Revue d'Histoire des Textes” 7 (2012) 37-116.

Lapidge M., The Metrical Calendar in the „Pembroke Psalter-Hours”, AnBol 129 (2011) 325-387.

Lequeux X., Le martyre Pamoun. Une nouvelle victime d'Apellianos?; à propos de POxy 4759, AnBol 129 (2011) 11-12.

Lemeni D., Dinamica îndrumării spirituale în tradiția pustiei egiptene din secolul al IV-lea, „Studi Teologice” 2011, nr 2, 19-28.

Lesieur B., Les derniers voyages de Pierre l'Ibère d'après Jean Rufus: chronologie et interprétation, AnBol 130 (2012) 5-39.

Licciardello P., Il culto dei santi nei manoscritti medievali dell'abbazia di San Fedele di Strumi-Poppi, „Hagiographica” 18 (2011) 135-196.

Licciardello P., Scrittura e riscrittura della Vita di san Fermano di Montelupone (BHL 3000-3001), AnBol 130 (2012) 89-150.

Lucchesi E., Deux témoins coptes de l'homélie sur l'archange Gabriel, attribuée à Jean Chrysostome, AnBol 129 (2011) 324-325.

Lucchesi E., Un fragment bohïrique du „,Martyre d'Isidore et Sané”, AnBol 129 (2011) 5-10.

Masson J., À la naissance des jeûnes dans la tradition copte, POC 62 (2012) 230-260.

Maraval P., Constantin et les lieux saints de Palestine, CPE 2011, nr 122, 26-42.

Montenegro J. - Castillo A., Las viudas consagradas en la Iglesia Occidental y su pervivencia en la Península Ibérica: Un ejemplo de continuidad, SMon 53 (2011) 337-361.

Moss C.R., The Discourse of Voluntary Martyrdom: Ancient and Modern, ChH 81 (2012) 531-551.

Muehlberger E., Salvage: Macrina and the Christian Project of Cultural Reclamation, ChH 81 (2012) 273-297.

Nardi C., Uno strano modo di pregare i passalorinchiti alle origini dell'esicasmo?, „Augustinianum” 51 (2011) 423-449.

Nelis J., Quand paganisme et catholicisme se rencontrent: quelquels observations concernant la nature du mythe de la romanité à l'Istituto di Studi Romani, „Latomus” 71 (2012) 176-192.

Nigro G.A., Dinamiche multietniche e interreligiose oltre il limes danubiano: Niceta, Inna e altri martiri goti, „Classica \& Christiana” 7 (2012) 201-220.

Nuzzo D., Reliquiario d'argento dal complesso ecclesiastico di San Pietro a Canosa, VetCh 48 (2011) 359-373.

Olivieri L.M.M., L'Old English Martyrology e il culto micaelico dal santuario garganico alla Northumbria, VetCh 48 (2011) 305-317.

Osiek C., The education of girls in early Christian ascetic traditions, „Studies in Religion" 41 (2012) 401-407.

Outtier B., Les pérégrinations d'une exhortation dans l'Orient chrétien, AnBol 129 (2011) 80.

Peretó Rivas R.A., Las mutaciones de la acedia: de la Patrística a la Edad Media, „Studium” 14 (2011) 159-173.

Popoiu D.M., Paradisul în viziunea Părinților din pustia Egiptului, „Studi Teologice” 2011, nr 2, 29-58. 
Raineri O., Gli Atti Etiopici di Abbā Nob, Martire Egziano, „Ethiopian Review of Cultures" 14 (2011) 223-282.

Rizzi M., Forme e obiettivi della polemica nel corpus agiografico smirneo, „Auctores Nostri" 9 (2011) 575-586.

Robertson D., „Lectio divina” and literary criticism. From John Cassian to Stanley Fish, „Cistercian Studies Quarterly” 46 (2011) 83-93.

Ruggieri V., ,Vita Nicolai Sionitae”: tracce eucologiche e ambiguità teologiche, ByzZ 104 (2011) 705-718.

Schroeder C.T., Sacrifice in Egyptian Monastic Culture: from Familial Renunciation to Jephthah's Lost Daughter, JECS 20 (2012) 269-302.

Simonetti M., Qualche osservazione sull'agiografia di San Nicola, VetCh 48 (2011) 115-126.

Simonetti M., Un nuovo libro su ortodossia ed eresia nella chiesa antica, „Adamantius” 18 (2012) 325-335.

Stewart C., The use of biblical texts in prayer and the formation of early monastic culture, ABR 62 (2011) 188-201.

Tams H., ,, Passio Pollionis” (BHL 6869): introduction, critical text and notes, SE 51 (2012) 9-34.

Teule H., The Idea of Perfection in the Spiritual Works of Gregory Barhebraeus (1226-1286), StPatr 51 (2011) 195-203.

Totti M., Il lessico dell'ascesi. Alcune osservazioni sulla 'psicologia spirituale’ nel Cristianesimo orientale ed in Epitteto, „Historia Religionum” 3 (2011) 47-64.

Van Uytfanghe M., L'origine et les ingrédients du discours hagiographique, SE 50 (2011) 35-70.

Wellington J.F., Encountering Christ in the Psalms: Antecedents of the Jesus Prayer in Eastern Monastic Psalmody c.350-c.450, StPatr 52 (2011) 19-26.

Whatley E.G., Textual Hybrids in the Transmission of the „Passio S. Eugeniae” (BHL 2666, 2667), „Hagiographica” 18 (2011) 31-66.

Yannopoulos P., Légende et fonds historique de la Passion des 60 ou 63 martyrs de Jérusalem, „Erytheia” 32 (2011) 159-186.

Zanghi V., Risposte e repliche di una santa martire: la passio Agathae, „Auctores Nostri" 9 (2011) 659-674.

Ziegler M., ,A die nativitatis narrandi initium sumam” (Vita Ambr. 2): Heilige und ihre Verwandten in lateinischen Heiligenviten der Spätantike, „Hagiographica” 18 (2011) 1-30.

\section{Archeologia i historia sztuki}

Bailet P. - Donabédian P. - Hartmann Virnich A. - Jorda Ch. - Marchand G. - Martinez D. - Schneider L., Nouvelles recherches sur l'ensemble paléochrétien et médiéval d'Ereruyk en Arménie, ,Antiquité Tardive” 19 (2011) 315-341.

Baratte F., La vaisselle précieuse à décor chrétien: un répertoire original?, „Antiquité Tardive" 19 (2011) 191-208.

Bejaoui F., Inscriptions inédites du Kef (antique Sicca Veneria, Tunisie), „Antiquité Tardive" 19 (2011) 307-314.

Bisconti F., Primi passi di un'arte cristiana. I processi di definizione e l'evoluzione dei significati, „Antiquité Tardive” 19 (2011) 35-46. 
Bonnekoh P., Nouvelles propositions pour l'iconographie de deux tombes de Thessalonique ( $\left(V^{e}-V^{e} s\right.$.) et remarques complémentaires sur certaines peintures de l'Agora et de Saint-Démétrius (VI ${ }^{-}-V I I^{e}$ s.), ,Antiquité Tardive” 19 (2011) 267-281.

Bouzek J., New Studies in Black Sea and Balkan Archaeology, „Eirene” 47 (2011) 179-191.

Bowes K., Christian Images in the Home, „Antiquité Tardive” 19 (2011) 171-190.

Braconi M., Dalle Bibbie miniate all'arte monumentale. A proposito dei cicli della Genesi e dell'Esodo su un arazzo dipinto dell'Abegg-Stiftung, VetCh 48 (2011) 39-62.

Brenk B., Apses, Icons and „Image Propaganda” before Iconoclasm, „Antiquité Tardive" 19 (2011) 109-130.

Caillet J.P., L'image du dédicant dans l'édifice cultuel (IVe-VIIe s.): aux origines de la visualisation d'un pouvoir de concession divine, „Antiquité Tardive” 19 (2011) 149-169.

Cantino Wataghin G., I primi Cristiani, tra imagines, historiae e pictura. Spunti di riflessione, „Antiquité Tardive” 19 (2011) 13-34.

Chiriac C., Un sigiliu paleocreştin de la Noviodunum, „Classica \& Christiana” 6 (2011) 377-386.

Creissen Th., La place du décor sculpté figuratif ou symbolique dans les édifices cultuels chrétiens de l'Antiquité tardive, „Antiquité Tardive” 19 (2011) 131-148.

De Cos J., Los orígenes de la vida religiosa: los monjes del desierto, „Vida Sobrenatural" 91 (2011) 209-217.

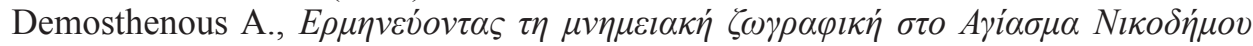

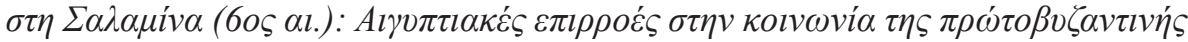
Kí $\pi \rho o v$, „Erytheia” 33 (2012) 31-56.

Dresken-Weiland J., Bilder im Grab und ihre Bedeutung im Kontext der Christianisierung der frühchristlichen Welt, „Antiquité Tardive” 19 (2011) 63-78.

Dulaey M., L'image et les Pères de l'Église. A propos du cubiculum F de la catacombe de la Via Latina, „Antiquité Tardive” 19 (2011) 47-62.

Engemann J., Die Himmelfahrt Christi. Eine neue Interpretation früher Bilder, JACh 54 (2011) 98-104.

Filipovic A., L'architecttura sepolcrale bizantina sulle isole di Gemile e Karacaören in Lycia. Parte II, OCP 78 (2012) 439-466.

Fritsch., Emmanuel, Ethiopian Liturgy and Church Architecture, „Ethiopian Review of Cultures" 14 (2011) 75-103.

Gaillard de Sémainville H., Décor chrétien des objets de parure. L'exemple des plaques-boucles mérovingiennes de Burgundia, „Antiquité Tardive” 19 (2011) 223-236.

Gudea N., Note de arheologie creştină. 7. Despre o gemă gnostică de la Garvăn/ Dinogetia (Moesia Inferior), „Classica \& Christiana” 6 (2011) 445-454.

Harreither R. - Huber M. - Pillinger R., Bibliographie zur Spätantike und frühchristlichen Archäologie in Österreich (mit einem Anhang zum spätantik-frühchristlichen Ephesos); 2010 erschienene Publikationen und Nachträge, „Mitteilungen zur christlichen Archäologie" 17 (2011) 107-113.

Kanitz E., The representation of the Other in Early Christian Art. The representation of Christian self-identity through the representation of the Other in the visual arts and its interaction with Judaism and Paganism, Angelicum" 89 (2012) 93-116. 
Khrushkova L., Early Christian architecture of the Caucasus: problems of typology, „Antiquité Tardive” 20 (2012) 343-357.

Leal Lobón M., El primer arte cristiano: El sarcófago de Junio Basso, „Isidorianum” 20 (2011) 517-552.

Logan A., Constantine, the „Liber pontificalis” and the Christian Basilicas of Rome, StPatr 50 (2011) 31-53.

Magana J.Á.D., La revalorización de lo clásico en la España tardoantigua y altomedieval. Un análisis a través de la decoración arquitectónica, „Antiquité Tardive” 19 (2011) 275-306.

Mailis A., The early Christian basilica and the later cemetery at Mariolata (Phocide). Transformations of a site beside the Great Isthmus Corridor Route, „Antiquité Tardive" 19 (2011) 303-321.

Martínez Frías J.M., La pasión de Cristo en el arte, „Staurós” 51 (2012) 5-72.

Mazzei B., La pittura e la scultura funerarie: Tangenze e divergenze nel processo di formazione del repertorio paleocristiano, „Antiquité Tardive” 19 (2011) 79-94.

Nassar M. - Turshan N., Geometrical mosaic pavements of the Church of Bishop Leontios at Yaamun (Northern Jordan), „Palestine Exploration Quarterly” 143 (2011) 41-62.

Peppard M., Illuminating the Dura-Europos Baptistery: Comparanda for the Female Figures, JECS 20 (2012) 543-574.

Ristow S., Ältester frühchristlicher Fund aus Aachen. Eine spätantike Sigillatascherbe mit christlicher Symbolik vom Katschhof, JACh 54 (2011) 142-145.

Rubery E., Papal Opposition to Imperial Heresies: Text as Image in the Church of Sta. Maria Antiqua in the Time of Pope Martin I (649-654/5), StPatr 50 (2011) 3-29.

Ruggieri V., In margine a Mylasa (Milas) bizantina: disjecta membra, OCP 77 (2011) 503-531.Sánchez Pardo J.C., Los contextos de fundacion de las iglesias tardoantiguas en Galicia (ss. V-VIII): substratos arqueológicos, distribución y significados, „Antiquité Tardive” 19 (2011) 255-273.

Snyder H.G., A second-century Christian inscription from the Via Latina, JECS 19 (2011) 157-195.

Spieser J.M., Le décor figuré des édifices ecclésiaux, „Antiquité Tardive” 19 (2011) 95-108.

Steigerwald G., Das Scheitelmosaik und das Epigramm des Papstes Xystus III (432440) am Triumphbogen von S. Maria Maggiore in Rom, JACh 54 (2011) 146-171.

Suárez González A., La Biblia Visigótica de la Catedral de León (Códice 6): primeros apuntes para un estudio arqueológico, „Estudios Humanisticos. Historia” 10 (2011) 179-196.

Tatz S., ,, Cella memoriae”. Eine sepulkrale Bauform in ihrer antiken Bedeutung und modernen Auslegung, JACh 54 (2011) 105-141.

Vannier M.A., La topographie de Jérusalem - le site de Bethleem, CPE 2011, nr 122, 48-50.

Yasin A.M., Reassessing Salona's Churches: „martyrium” evolution in question, JECS 20 (2012) 59-112.

\section{Biblia}

Auwers J.M., Les Pères, lecteurs de l'Écriture. Chroniques d'exégèse patristique (2), „Revue d'histoire ecclésiastique” 107 (2012) 311-327. 
Boer R., Marxism and the spatial analysis of early Christianity. The contribution of G.E.M. de Ste. Croix, „Religion” 41 (2011) 411-430.

Bogaert P.M., Job latin chez les Péres et dans les Bibles. D’une version courte à des versions longues sur le grec et sur l'hébreu, RBen 122 (2012) 48-99.

Caballero J.L., Los deberes familiares en Col 3, 18 - 4, 1. La exégesis medieval occidental y la herencia de los Padres, ScT 43 (2011) 59-85; 323-344.

Caballero J.L., Los deberes familiares en Col 3,18-4,1. La exégesis medieval occidental y la herencia de los Padres, ScT 43 (2011) 59-85.

Carnevale L., Giobbe, il malato: proposte di lettura tra Bibbia, agiografia e scienza, VetCh 49 (2012) 161-170.

Chávez E., El estudio de Flavio Josefo y la historicidad del Nuevo Testamento, „Anámnesis” 22 (2012) nr 43, 31-58.

Ciarlo D., I prologhi nei commenti patristíci ai profeti tra quarto e quinto secolo, „Augustinianum” 52 (2012) 383-416.

Collins Clifford C.J, Noah, Deucalion, and the New Testament, „Biblica” 93 (2012) 403-426.

Costa J., Le récit de la création dans l'exégèse des rabbins et des Pères de l'Église: essai de comparaison, CPE 2012, nr 125, 9-14.

Courtray R., L'homme, image de César ou image de Dieu? L'épisode du tribut à César chez quelques Pères, CPE 2012, nr 128, 14-27.

Croy Clayton N. - Connor A.E., Mantic Mary?. The Virgin Mother as prophet in Luke 1.26-56 and the early Church, ,Journal for the Study of the New Testament” 34 (2012) 254-276.

Dogniez C., L'apport des études sur la Septante pour la Genèse, CPE 2012, nr 125, $15-22$.

Elledge C.D., Future resurrection of the dead in early Judaism. Social dynamics, contested evidence, „Currents in Biblical Research” 9 (2011) 394-421.

Felix A., Göttliche Demut und teuflischer Hochmut. Exegetische Beobachtungen zu Prov 3, 34 LXX, „Biblische Notizen” 2012, nr 155, 23-41.

Graves M., The biblical scholarship of a fourth-century woman. Marcella of Rome, EThL 87. 2011, 4 375-391.

Gronchi M., Il sapore dei Padri della Chiesa nell'esegesi biblica, „Rassegna di teologia" 52 (2011) 493-499.

Hawk B., A fragment of Colossians with Hiberno-Latin glosses in St. Gall, Stiftsbibliothek, Cod. Sang. 1395, SE 51 (2012) 233-256.

Holladay C.R., Acts and the fragmentary Hellenistic Jewish authors, „Novum Testamentum" 53 (2011) 22-51.

Hübenthal S., Pseudepigraphie als Strategie in frühchristlichen Identitätsdiskursen?. Überlegungen am Beispiel des Kolosserbriefs, „Studien zum Neuen Testament und seiner Umwelt" 36 (2011) 61-92.

Kreinecker Ch.M., The earliest commentaries on Paul as sources for the biblical text. A new research project at the Institute for Textual Scholarship and Electronic Editing at the University of Birmingham, „Early Christianity” 3 (2012) 411-415.

Lannoy A., St. Paul in the early $20^{\text {th }}$ century history of religions. , the mystic of Tarsus " and the pagan mystery cults after the correspondence of Franz Cumont and Alfred Loisy, „Zeitschrift für Religions- und Geistesgeschichte” 64 (2012) 222-239. 
Lefebvre Ph., Le Fils perdu et retrouvé. Luc 1-2: une lecture de la Genèse entre tradition juive et culture païenne, CPE 2012, nr 125, 23-38.

Loiseau A.F., Deux arguments en faveur de l'antériorité de la traduction grecque d'Isaïe par rapport à celle des XII, „Adamantius” 17 (2011) 257-261.

MacAdam H.I., A mixed quartet. Jesus; James the Just; The Gospel of Mark; The Hebrew Gospel; a review article (part 2 of 2), ,Theological Review” 32 (2011) 45-66.

Massey P.T., Is there a case for elite Roman ,new women” causing division at Corinth?, RB 118 (2011) 76-93.

Massey P.T., Long hair as a glory and as a covering. Removing an ambiguity from 1 Cor 11:15, „Novum Testamentum” 53 (2011) 52-72.

Mattei P., L'homme image de Dieu dans la première littérature latine chrétienne, CPE 2012, nr 128, 3-13.

Menken M.J., Striking the shepherd. Early Christian versions and interpretations of Zechariah 13,7, „Biblica” 92 (2011) 39-59.

Merino Rodríguez M., Los comentarios patrísticos a la Bíblia, „Theologica” 47 (2012) 415-438.

Nebel M., La notion néotestamentaire de „,diakonia”. Une difficile reconnaissance, „Revue d'éthique et de théologie morale” 68 (2012) 79-102.

Nicklas T., Paulus und die Errettung Israels. Röm 11,25-36 in der exegetischen Diskussion und im jüdisch-christlichen Dialog, „Early Christianity” 2 (2011) 173-197.

Nodet É., Moïse ou Platon ou ...?, RB 118 (2011) 595-604.

Petrantoni G., La traslitterazione greca del Salmo 78, 77 di Damasco e la diglossia nel mondo arabo, ,Rivista di Cultura Classica e Medioevale” 53 (2011) 285-308.

Pratscher W., Die Rezeption des Neuen Testaments bei den Apostolischen Vätern, ThL 137 (2012) 139-152.

Puigdollers i Noblom R., El significat dels termes ,,Natzarè ”, ,Natzoreu” $i$,,Natzorè ”, en el Nou Testament segons el Còdex Beza, „Butlletí de l'Associació Bíblica de Catalunya" 2011, nr 108, 23-32.

Scherer H., Pompe und Bekenntnis. Zum Hintergrund von 1 Kor 12,1-3, „Biblische Zeitschrift" 55 (2011) 103-114.

Schwienhorst-Schönberger L., Wiederentdeckung des geistigen Schriftverständnisses. Zur Bedeutung der Kirchenväterhermeneutik, ThG 101 (2011) 402-425.

Simonetti M., L'interpretazione della Scrittura tra Alessandria e Antiochia, „Auctores Nostri” 9 (2011) 65-80.

Stegemann E.W., Apokalyptik und Universalgeschichte im antiken Herrschaftsdiskurs, ThZ, 67 (2011) 1-24.

Stenschke Ch.W., ,.... sandten die Apostel zu ihnen Petrus und Johannes” (Apg 8,10). Überörtliche Verbindungen der urchristlichen Gemeinden in der Darstellung der Apostelgeschichte des Lukas, EThL 87 (2011) 433-453.

Ugenti V., Il catalogo paolino dei vizi nella polemica pagana, „Auctores Nostri” 9 (2011) 161-168.

Urs von Balthasar H., Patrística, Escolástica y nosotros, „Toletana” 2011, nr 24, 55-102. Tassin C., Au commencement était ,, la maison”. Regard sociothéologique sur les origines de la mission chrétienne, RB 118 (2011) 94-108. 
Theobald Ch., Exégèse critique, exégèse patristique. Introduction, RSR 99 (2011) 167-170.

Tucker Ferda S., The Seventy Faces of Peter's Confession: Matt. 16:16-17 in the History of Interpretation, „Biblical Interpretation” 20 (2012) 421-457.

Tuckett Ch., The Gospel of Mary, „Revista Catalana de Teología” 37 (2012) 111-129.

Van Parys M., De l'Horeb au Thabor. Le Christ transfiguré dans les homélies byzantines, „Studi Teologice” 2011, nr 1, 9-34.

Vannier M.A., Les commentaires patristiques de la Genèse, expression de la rencontre entre judaïsme et christianisme, CPE 2012, nr 125, 2-8.

Vegge T., Vielfalt von Lernen und Lehren im Neuen Testament, „Glaube und Lernen” 27 (2012) 125-138.

Vörös G., Machaerus. The Golgotha of Saint John the Baptist, RB 119 (2012) 232-270.

Vössing K., Das ,,Herrenmahl” und 1 Cor. 11 im Kontext antiker Gemeinschaftsmähler, JACh 54 (2011) 41-72.

Witulski Th., Die Datierung der Ap in die Zeit des Claudius. Eine exegetische Möglichkeit?, „Estudios Bíblicos” 69 (2011) 79-91.

Wright W.M., The literal sense of Scripture according to Henri de Lubac. Insights from patristic exegesis of the transfiguration, „Modern theology” 28 (2012) 252-277.

Yates J., El uso de Rm 2, 14-15 en la tradición cristiana latina, ca. 365 - ca.411, excepto Agustín, „Augustinus” 56 (2011) 235-248.

\subsection{Apokryfy}

Abraha T., Some Philological Notes on the Mäúeüäfä 'Éräfétä läMaryam „Liber Requiei” (LR), „Apocrypha” 23 (2012) 221-245.

Amengual i Batle J., El prólogo hagiográfico de la Carta de Severo de Menorca (418), primer testimonio de la llegada de los Hechos Apócrifos de San Juan a Occidente y las transformaciones del priscilianismo en la Tarraconense y Mediodía de las Galias, SE 50 (2011) 265-315.

Amsler F., La „Translatio Philippi”, survie ou seconde mort de Philippe?, „Apocrypha” 22 (2011) 115-134.

Arcari L., 2Enoch and the Messianic Son of Man. A Triangular reading between the „Book of Parables of Enoch”, the „,Testament of Abraham” and 2Enoch, „Henoch” 22 (2011) 88-93.

Bain K., Socioeconomic status in early Christianity and Thecla's rejection of marriage, ,Journal of Feminist Studies in Religion” 27 (2011) 51-69.

Baslez M.F., Le travail de mémoire dans les Actes apocryphes de Paul, „Apocrypha” 22 (2011) 87-104.

Beyers R., La "Règle de Marie”: caractère littéraire et inspiration monastique, „Apocrypha” 22 (2011) 49-86.

Beyers R., The „Transmission of Marian” Apocrypha in the Latin Middle Ages, „Apocrypha” 23 (2012) 117-140.

Bovon F., Beyond the canonical and the apocryphal books, the presence of a third category: the books useful for the soul, HTR 105 (2012) 125-137.

Bovon F., The Corpus Christianorum „Series Apocryphorum” and the Association pour l'Étude de la Littérature Apocryphe Chrétienne, „Early Christianity” 3 (2012) 137-143. 
Burke T., Depictions of children in the apocryphal Infancy Gospels, „Studies in Religion" 41 (2012) 388-400.

Callon C., Secondary Characters Furthering Characterization: The Depiction of Slaves in the „Acts of Peter”, JBL 131 (2012) 797-819.

Chapa J., A newly published „, Gospel fragment”, „Early Christianity” 3 (2012) 381389.

Diesenberger M., Reworking the „Virtutes apostolorum” in the Salzburg SermonCollection (1 ${ }^{\text {st }}$ quarter of the ninth century), „Apocrypha” 23 (2012) 47-64.

Duchemin J.M., Un réexamen des notices de Théodore Bar Konaï sur les mandéens, „Apocrypha” 23 (2012) 171-207.

Foster P., The Gospel of Peter. Directions and issues in contemporary research, „Currents in Biblical Research” 9 (2011) 310-338.

Gounelle R., Editing a Fluid and Unstable Text: The Example of the „Acts of Pilate” (or ,, Gospel of Nicodemus”), „Apocrypha” 23 (2012) 81-97.

Graves M., Apocryphal elements in the New Testament and Qur'ān, „Journal of Ecumenical Studies" 47 (2012) 152-166.

Henze M., 4 Ezra and 2 Baruch: Literary Composition and Oral Performance in First-Century Apocalyptic Literature, JBL 131 (2012) 181-200.

Izydorczyk Z., On the „Evangelium Nicodemi” before Print: Towards a New Edition, „Apocrypha” 23 (2012) 99-116.

Lusini G., The Ethiopic version of the „Story of Ahiqar” (Mäshșhafä Hiqar), „Rassegna di Studi Etiopici” 3 (2011 [2012]) 219-248.

Miceli C.A., An account of the York University Christian Apocrypha Symposium Series: "Ancient gospel or modern forgery? The secret gospel of Mark in debate” (held at Vanier College on April 29th, 2011), „Apocrypha” 22 (2011) 265-272.

Moñivas Berlanas J., La influencia de los evangelios apócrifos de la Natividad en el calendario litúrgico del primer milenio, „Toletana” 2011, nr 24, 147-204.

Nedungatt G., The Apocryphal „Acts of Thomas” and Christian Origins in India, „Gregorianum” 92 (2011) 533-557.

Ó Dochartaigh C., Homiletic Texts and the Transmission of Eschatological Apocrypha in a Medieval Irish Context, „Apocrypha” 23 (2012) 141-153.

Otranto R., Costantino Simonidis e la Lettera di Aristea a Filocrate, VetCh 48 (2011) 319-334.

Patterson St.J., Apocalypticism or Prophecy and the Problem of Polyvalence: Lessons from the „, Gospel of Thomas”, JBL 130 (2011) 795-817.

Pfeifer M., Götterknabe, Wunderkind : apokryphe Kindheitserzählungen, „Katechetische Blätter” 136 (2011) 433-437.

Piovanelli P., Thursday night fever: dancing and singing with Jesus in the ,, Gospel of the Savior" and the „Dance of the Savior around the Cross ”, „Early Christianity” 3 (2012) 229-248.

Rizzi M., Migrations of the Antichrist: on European Apocalypses, „Annali di Scienze Religiose" 5 (2012) 223-233.

Rose E., ,,Virtutes apostolorum”: Editorial Problems and Principles, „Apocrypha” 23 (2012) 11-45.

Rose E., La réécriture des „Actes apocryphes des Apôtres” dans le Moyen-Âge latin, „Apocrypha” 22 (2011) 135-166. 
Santamaría del Río L., Otro Jesús: Evangélios apócrifos y cultura actual, NV 35 (2011) 5-46.

Schonhoffer T.N., The relationship of the Gospel of Peter to the canonical gospels. A composition of critical arguments, EThL 87 (2011) 229-249.

Schröter J., The apocryphal Gospels in the context of early Christian theology. Colloquium Biblicum Lovaniense LX (July 26-28, 2011), EThL 88 (2012) 233244.

Shoemaker S.J., From mother of mysteries to Mother of the Church: the institutionalization of the Dormition Apocrypha, „Apocrypha” 22 (2011) 11-47.

Shoemaker S.J., New Syriac Dormition Fragments from Palimpsests in the Schøyen Collection and the British Library, „Le Muséon” 124 (2011) 259-278.

Stone M.E., Three apocryphal fragments from Armenian manuscripts, „Apocrypha” 23 (2012) 939-946.

Teeuwen M., The Digital Edition: New Possibilities and Challenges, „Apocrypha” 23 (2012) 155-168.

Twelftree G.H., Exorcism and the defeat of Beliar in the „, Testaments of the Twelve Patriarchs", VigCh 65 (2011) 170-188.

Van Acker M., A (Socio)linguistic Approach to Hagiographic Text Transmission: the Torino Collection Biblioteca Nazionale D.v.3. (8th/9th c.), „Apocrypha” 23 (2012) 65-80.

Vegas Montaner L., Relecturas del Antiguo Testamento en los apócrifos judios, EstB 70 (2012) 185-216.

Vinogradov A., André: du prédicateur encratite à l'apôtre byzantin, „Apocrypha” 22 (2011) 105-114.

Vinzent M., Give and Take amongst Second Century Authors: The „Ascension of Isaiah”, the ,Epistle of the Apostles” and Marcion of Sinope, StPatr 50 (2011) 105-129.

Wayment Th.A. - Ladenheim A., A new fragment of the „Protevangelium Jacobi”, HTR 104 (2011) 381-384.

Williams P.J., The Bible, the Septuagint, and the Apocrypha: a consideration of their singularity, „Apocrypha” 23 (2012) 169-180.

\subsection{Gnostycyzm}

Albrile E., L'epica mancata. Appunti di biopolitica gnostica, „Antonianum” 86 (2011) 783-807.

Barc B., Le mythe gnostique de Seth et de sa race est-il conforme aux Écritures hébraïques?, „Adamantius” 18 (2012) 71-82.

Beatrice P.F., Greek philosophy and gnostic soteriology in Heracleon's „Hypomnemata”, „Early Christianity” 3 (2012) 188-214.

Cahana J., Gnostically queer. Gender trouble in gnosticism, „Biblical Theology Bulletin" 41 (2011) 24-35.

Camplani A., L', Apocrifo di Giovanni” ela primitiva tradizione gnostica. Presentation of the theme section, „Adamantius” 18 (2012) 59-61.

Cherubini B., Remarques sur le personnage de Marcion dans l'interprétation de Justin Martyr: un pseudoprophète?, „Apocrypha” 22 (2011) 233-252.

Cortès E., La influéncia del moviment gnòstic en la història cultural europea, „Revista Catalana de Teología” 37 (2012) 153-178. 
Dubois J.D., La tradition johannique dans l',, Apocryphe de Jean”, „Adamantius” 18 (2012) 108-117.

Dunderbeg I., Valentinus and his school, „Revista Catalana de Teología” 37 (2012) 131-151.

Fleta Soriano R., Cristianismo y gnosticismo en el siglo I d.C, „Revista Aragonesa de Teología” 18 (2012) nr 36, 51-68.

Franzmann M., Personal and cosmic spaces of salvation in James and „, The Gospel of Judas", RSLR 48 (2012) 155-166.

Gagné A., Jésus, la lumière et le Père vivant. Principe de gémellité dans l',Évangile selon Thomas”, „Apocrypha” 23 (2012) 209-221.

Gathercole S.J., Luke in the Gospel of Thomas, NTS 57 (2011) 114-144.

Gathercole S.J., Named testimonia to the „, Gospel of Thomas ”. An expanded inventory and analysis, HTR 105 (2012) 53-89.

Gianotto C., Introduzione: L',Apocrifo di Giovanni”, „Adamantius” 18 (2012) 62-64.

Gianotto C., La dissimulazione nello gnosticismo, „Annali di Scienze Religiose” 4 (2011) 71-82.

Grosso M., A new link between Origen and the „, Gospel of Thomas”. Commentary on Matthew 14,14, VigCh 65 (2011) 249-256.

King K.L., Reading sex and gender in the ,, Secret Revelation of John”, JECS 19 (2011) 519-538.

León A.S., Elementos principales de la crítica de Hans Jonas a la modernidad, „Mayéutica” 38 (2012) 103-109.

Létourneau P., The „Dialogue of the Savior” as a witness to the late Valentinian tradition, VigCh 65 (2011) 74-98.

Logan A., The „Apocryphon of John” and the Development of the „Classic' Gnostic Myth, „Adamantius” 18 (2012) 136-150.

Markschies Ch., Individuality in some Gnostic authors. With a few remarks on the interpretation of Ptolemaeus, Epistula ad Floram, ZACh 15 (2011) 411-430.

Marshal J.W., Misunderstanding the New Paul: Marcion's Transformation of the ,,Sonderzeit” Paul, JECS 20 (2012) 1-29.

Muehlberger E., Preserving the divine. Autos-prefixed generative terms and the „Untitled treatise” in the Bruce Codex, VigCh 65 (2011) 311-328.

Paget Carleton J. - Vinzent M., Marcion and the resurrection. Some thoughts on a recent book, ,Journal for the study of the New Testament” 35 (2012) 74-102.

Patterson S.J., The view from across the Euphrates, HTR 104 (2011) 411-431.

Pleše Z., Intertextuality and Conceptual Blending in the „Apocryphon of John”, „Adamantius" 18 (2012) 118-135.

Plisch U.K., The Right and the Left Penis. Remarks on Textual Problems in the „Apocryphon of John”, „Adamantius” 18 (2012) 65-70.

Popkes E.E., The Gnostic Myth: Protology, „Revista Catalana de Teología” 37 (2012) 55-66.

Pratscher W., Die Bedeutung des Petrus in gnostischen Texten, „Studien zum Neuen Testament und seiner Umwelt" 37. 2012 111-150.

Puig i Tàrrech A., L',,Evangeli de Tomàs”: el pas del judeocristianisme al gnosticisme, „Revista Catalana de Teología” 37 (2012) 85-110.

Renaud-Grosbras P., „Parago”. Promenade exégétique dans le Nouveau Testament et le logion 42 de l', Évanglile de Thomas”, EThR 86 (2011) 209-220. 
Rius-Camps J., Les fonts patrístiques del gnosticisme: descripció i avaluació, „Revista Catalana de Teología" 37 (2012) 29-43.

Roth D.T., The text of the Lord's Prayer in Marcion's Gospel, ZNW 103 (2012) 47-63.

Sánchez S.J.G., Les priscillianistes ou „Les autres gnostiques”, „Emerita” 80 (2012) 125-148.

Schenke G.R., An update on the „, Gospel of Judas”. (after additional fragments resurfaced), ZNW 102 (2011) 110-129.

Schmid H., Eucharistie und Opfer. Das „Evangelium des Judas” im Kontext von Eucharistiedeutungen des zweiten Jahrhunderts, „Early Christianity” 3 (2012) 85-108.

Schröter J., Concept, Origin and Context of the „Gnostic movement”, „Revista Catalana de Teología" 37 (2012) 9-27.

Schwarz J.K., Die Kultpolemik im „Evangelium des Judas”, „Early Christianity” 3 (2012) 59-84.

Steenberg M.C., The „, Gospel of Truth” and the Truth of the Gospel: Assessing the Scope of Valentinian Influence on the Thought of St Irenaeus, StPatr 50 (2011) 89-103.

Stori E., Vangelo di Tommaso e „Diatessaron”: traiettorie parallele. Il „Diatessaron” e i problemi della ricerca, „Adamantius” 18 (2012) 151-177.

Tripaldi D., Dio e gli dèi: tracce di teogonia egiziana nell',,Apocrifo di Giovanni?, „Adamantius” 18 (2012) 83-107.

Vicens X.M., Les fonts gnòstiques: descripció i avaluació, „Revista catalana de teología" 37 (2012) 45-54.

Wucherpfennig A., Was ist Gnosis?, ThPh 87 (2012) 251-261.

\section{Patrystyka i średniowiecze bizantyńskie oraz lacińskie}

Alexandrova S., Typology and Chronology of the Handmade Pottery of the Roman and Early Byzantine Period (I-VI c.) on the Territory of Bulgaria, „Archaeologia Bulgarica" 16 (2012) nr 1, 33-46.

Andersen M.G., The Second Recension of the „,Martyrology of Usuardus”, RBen 121 (2011) 382-392.

Casas Olea M., San Sisinio y Sichael: los amuletos en corteza de abedul como fuente sobre la magia cristiana bizantinoeslava, „MHNH” 11 (2011) 273-284.

Ceulemans R., Nouveaux témoins manuscrits de la chaîne de Polychronios sur le Cantique (CPG C 83), ByzZ 104 (2011) 603-628.

Getcha J., L'hymnographie mariale Byzantine, CPE 2011, nr 121, 42-61.

Glatthaar M., Bernard von Réome und die Datierung der Musica disciplina Aurelians, RBen 121 (2011) 357-381.

Izdebski A., The Changing Landscapes of Byzantine Northern Anatolia, „Archaeologia Bulgarica” 16 (2012) nr 1, 47-66.

Jezek V., Byzantium and Ethiopian monasticism, „Byzantinoslavica” 70 (2012) nr 1-2, 97-112.

Jordanov I., The Diocese of Thrace $\left(5^{\text {th }}-7^{\text {th }}\right.$ c.) according to the Sigillographic Data, „Archaeologia Bulgarica” 16 (2012) nr 3, 57-76.

Kostenec J., Paul the Silentiary's description of Hagia Sophia in the light of new archaeological evidence, „Byzantinoslavica” 69 (2011) nr 3, 88-105. 
Lauritzen D., „Exegi monumentum”. L'ekphrasis autonome de Jean de Gaza, „Byzantinoslavica” 69 (2011) nr 3, 61-79.

Leovigildo de Córdoba., El hábito de los clérigos, trad. J.J. Fresnillo Ahijón, „Toletana” 2011, nr 24, 229-262.

Lévy A., Liberté et „Structure profonde” des régimes politiques en Orient byzantin et en Occident latin, „Istina” 2011, nr 1, 179-206.

Lemeni D., „Şcoala din Gaza”: o renaştere a îndrumării spirituale în tradiția bizantină timpurie, ,Studi Teologice” 2012, nr 1, 147-166.

Martín J.C., El tratado „Item alia quaestiones in quibus sunt nonnulle de Genesi” conservado en Montecassino, Biblioteca dell'Abazia, 29: edición y estudio, SE 50 (2011) 341-412

Meeder S., Boniface and the Irish Heresy of Clemens, ChH 80 (2011) 251-280.

Odorico P., Monuments de rêve. Représentations architecturales dans la littérature byzantine, „Byzantinoslavica” 69 (2011) nr 3, 33-47.

Parrinello R.M., L'autocoscienza delle origini nella tradizione monastica bizantina: il caso di Giorgio Monaco, „Adamantius” 17 (2011) 133-153.

Perrone L., Byzantine Monasticism in Gaza and in the Judaean Desert: a Comparison of Their Spiritual Traditions, POC 62 (2012) 6-22.

Radle G., The Development of Byzantine Marriage Rites as Evidenced by Sinai Gr. 957, OCP 78 (2012) 133-148.

Rodríguez J.M.R., La composición del Santo Myron en el rito bizantino, „Liturgia y espiritualidad" 43 (2012) 181-201.

Roszak P., La práctica exegética de Alcuino de York, „Facies Domini” 3 (2011) 503-514.

Somers V., Mélanges de littérature et de civilisation byzantines: à propos de quelques ouvrages (plus o moins) récents, RHE 106 (2011) 571-586.

Timotin A., La vision du paradis d'André Salos. Héritages anciens et idéologie impériale byzantine, RHR 228 (2011) 389-402.

Ventrella G., Mito pagano e interpretatio christiana a Gaza nel VI secolo. L'immagine della rosa fiorita sull'ulivo selvatico in Giorgio Grammatico, „Athenaeum” 100 (2012) 385-404.

Villani E., Le sezioni „lambda” e ,rho” dell'Ecloga vocum atticarum aucta di Tommaso Magistro nel codice Ambrosiano M 51 sup, „Aevum” 86 (2012) 713-758.

\section{Autorzy}

\section{Acta Martyrum}

Isetta S., Una 'doppia vittoria: la passio Victoris et Coronae, „Auctores Nostri” 9 (2011) 639-658.

Luongo G., Tra giudice e imputato. La polemica negli „Atti e Passioni” dei martiri, „Auctores Nostri” 9 (2011) 587-620.

\section{Afrahat}

Morrison C.E., Scenes from first and second Samuel retold in Aphrahat's fourteenth demonstration, „Exhortatoria”, ParOr 36 (2011) 169-189.

Patteruparampil J., A re-reading of Aphrahat, ,, Demonstration” 1.19, ParOr 36 (2011) 271-285. 


\section{Ambrozjaster}

Ciampoli P., Ambrosiaster e o ,Commentarius in Epistulam ad Romanos”, „Itinerarium” 58 (2012) 117-141.

De Bruyn Th.S., Ambrosiaster's interpretations of Romans 1, 26-27, VigCh 65 (2011) 463-483.

Dels Sants Gros i Pujol M., Les catequesis prepasquals de l'Ambrosiaster, „Revista Catalana de Teología” 37 (2012) 687-696.

Lunn-Rockliffe S., Bishops on the chair of pestilence. Ambrosiaster's polemical exegesis of Psalm 1.1, JECS 19 (2011) 79-99.

Pereira Lamelas I. - Ciampoli P., Ambrosiaster e o „, Commentarius in Epistulam ad Romanos”, „Itinerarium” 58 (2012) nr 202, 117-141.

\section{Ambroży z Mediolanu}

Alzati C., San Barnaba apostolo e la Chiesa Ambrosiana. Significati ecclesiologici della ripresa a Milano di una tradizione agiografica greca, RSLR 48 (2012) 3-32.

Atkins J.W., The ,officia” of St. Ambrose's „,De officiis”, JECS 19 (2011) 49-77.

Bernardini P., Bibliografia Ambrosiana 2007, „Annali di Scienze Religiose” 4 (2011) 289-328.

Bernardini P., Bibliografia Ambrosiana 2008-2009, „Annali di Scienze Religiose” 5 (2012) 289-346.

Blumberg A., Ambrosius von Mailand und die Metapher von der Besieglung mit dem Heiligen Geist in seinen Taufkatechsen „De sacramentis” (sacr. VI 2, 6-9) und seiner systematischen Schrift „De Spiritu Sancto” (I 6, 78-80): zwei unterschiedliche Textgattungen im Vergleich, SE 51 (2012) 59-78.

Bucci T., Echi di sapienza pagana nel „,De Nabuthae historia” di Ambrogio, „Classica \& Christiana" 6 (2011) 337-386.

Cipriani N., Las obras de san Ambrosio en los escritos de san Agustín anteriores al episcopado, „Augustinus” 56 (2011) 385-424.

Coppa G., Ambrogio è vivo!, „Studia Ambrosiana” 5 (2011) 5-17.

Cougil R.G., Principios mistagógico-pastorales que brotan del „,De mysteriis” de san Ambrosio, „Liturgia y Espiritualidad” 42 (2011) 142-153; 218-229.

Cracco Ruggini L., I barbari e l'impero prima e dopo il 410 (in tema di provvidenzialismo), „Studia Ambrosiana” 5 (2011) 21-48.

De Apellániz Sainz-Trápaga S., La coherencia del cristiano ante el ejercicio de la autoridad en el epistolario político de Ambrosio de Milán, „Studia Ambrosiana” 5 (2011) 229-294.

Doerfler M., Ambrose's Jews: the creation of Judaism and heterodox Christianity in Ambrose of Milan 's „Expositio Evangelii secundum Lucam”, ChH 80 (2011) 749-772.

Gannaway E., Seeing God through the tomb in Ambrose of Milan, „Studia Ambrosiana” 6 (2012) 213-230.

Grant R., Weapons Strong for God : the Moral Theology of Ambrose of Milan applied to war, torture and capital punishment, ,Studia Ambrosiana” 5 (2011) 195-227.

Grant R.M., Weapons strong for God. The moral theology of Ambrose of Milan applied to war, torture and capital punishment, „Studia Ambrosiana” 5 (2011) 195-227.

Lassandro D., Barbarici motus e bellorum procellae in Ambrogio, „Studia Ambrosiana” 5 (2011) 65-76.

Lassandro D., I paradigmi della controversia „,De ara Victoriae” tra il senatore pa- 
gano Simmaco e il vescovo Ambrogio, „Auctores Nostri” 9 (2011) 359-368.

Marcone A., I matrimoni tra romani e barbari: la legislazione tardoimperiale e la testimonianza ambrosiana, „Studia Ambrosiana” 5 (2011) 121-132.

Marti R., Der Hymnus ambrosianus in der kroatischen (lateinschriftlichen) Überlieferung, ,Slavica Ambrosiana” 2 (2011) 59-88.

Nauroy G., La création de l'homme $(G n$ 1, 26) dans une lecture critique de Philon le Juif: la lettre 29 (43M) d'Ambroise de Milan face au „,De opificio mundi”, CPE 2012, nr 125, 39-49.

Navoni M., Ibarbari nella ,,Vita Ambrosii” di Paolino da Milano, „Studia Ambrosiana” 5 (2011) 169-192.

Palumbo S., La polemica ,in divites” di Ambrogio e le omelie VI e VII di Basilio, „Auctores Nostri” 9 (2011) 369-386.

Pangerl D.C., Von der Kraft der Argumente. Die Strategien des römischen Stadtpräfekten Symmachus und des Bischofs Ambrosius von Mailand beim Streit um den Victoriaaltar im Jahre 384, RQ 107 (2012) 1-20.

Pipitone G., Il dono e i poveri: la trattazzione de beneficiis nel „, De officiis ministrorum" di Ambrogio, SE 50 (2011) 133-183.

Piredda A.M., „,Etsi foris homo cernitur, intus bestia fremit” (Ambr., In Luc. 7, 52). Un esempio ambrosiano di ritratto polemico, „Auctores Nostri” 9 (2011) 475-490.

Pizzolato L.F., Ambrogio e gli Unni, „Studia Ambrosiana” 5 (2011) 77-93.

Sannazaro M., Gog iste Gothus est: presenze barbariche a Milano e in Lombardia tra fine IV e inizi V secolo alla luce delle testimonianze archeologiche ed epigrafiche, „Studia Ambrosiana” 5 (2011) 95-117.

Siniscalco P., L'idea di Roma in Ambrogio, „Studia Ambrosiana” 5 (2011) 49-64.

Stolle V., ,, Nun komm der Heiden Heiland ... ”. Stichwortverknüpfung, Begriffauffaltung und Textkürzung, „Lutherische Theologie und Kirche” 35 (2011) 19-30.

Tampellini S., Le „, Omelie su Luca” da Origene a Gerolamo (e Ambrogio): considerazioni introduttive, „Adamantius” 18 (2012) 226-232.

Van Reisen H., San Ambrosio y San Agustín sobre la negación de Pedro, „Mayéutica” 37 (2011) 373-384.

Velinova V., Le Vite estese di sant'Ambrogio di Milano nella letteratura slava ortodossa, „Slavica Ambrosiana” 2 (2011) 3-57.

Visonà G., Gog iste Gothus est: l'ombra di Adrianopoli su Ambrogio di Milano, „Studia Ambrosiana” 5 (2011) 133-167.

\section{Anastazy Synaita}

Kalthoff E., Hat die Darstellung des gekreuzigten Christus mit geschlossenen Augen ihren Ursprung im Hodegos des Anastasios vom Sinai?: Versuch einer Klarstellung, OrtF 26 (2012) 53-63.

\section{Andrzej z Cezarei}

Hernández J. Jr., The Relevance of Andrew of Caesarea for New Testament Textual Criticism, JBL 130 (2011) 183-196.

\section{Anonim}

Arcidiacono C., Il centone virgiliano cristiano „, Versus ad gratiam Domini”, ,Rivista di Cultura Classica e Medioevale" 53 (2011) 309-356. 
Diethart J. - Voigt W., Bedeutet necrotáphos in der ,Historia Monachorum in Aegypto” wirklich auch Grabräuber?, ByzZ 104 (2011) 629-632.

Raineri O., Omelia del Salvatore (Trattato etiopico sulla pasione di Cristo), OCP 77 (2011) 93-151.

\section{Antoni Pustelnik}

Giorda M., La paternità carismatica di Antonio, „Rivista Lasalliana” 78 (2011) 19-30.

\section{Apolinary z Laodycei}

Capone A., Apollinarismo e geografia ecclesiastica: luoghi e forme della polemica, „Auctores Nostri” 9 (2011) 457-474.

Ceulemans R., Apollinaris of Laodicea in the Catenae as a source of hexaplaric readings, ZACh 15 (2011) 431-449.

Ceulemans R., Unknown Hexaplaric readings of Ezekiel, Isaiah and Psalms, offered by Apollinaris of Laodicea, ZAW 123 (2011) 406-423.

Cipriani N., Ecos antiapolinaristas y aristotelismo en la polémica de Juliano de Eclana, „Augustinus” 56 (2011) 269-284.

\section{Apophtegmata Patrum}

Marinides N., Religious Toleration in the Apophthegmata Patrum, JECS 20 (2012) 235-268.

\section{Aryston z Pelli}

Bovon F. - Duffy J.M., A new Greek fragment from Ariston of Pella's dialogue of Jason and Papiscus, HTR 105 (2012) 457-465.

\section{Asteriusz z Amazei}

Chouvarda T., Der Märtyrer im enkomiastischen Werk des Asterius von Amaseia. Theologische Bemerkungen, OrtF 25 (2011) nr 2, 33-43.

\section{Atanazy Aleksandryjski}

Alba Lopez A., La fuga de Atanasio de Alejandría. Una construcción apologética en torno a Mt 10, 23 y sus antecedentes patrísticos, SMon 53 (2011) 317-328.

Bossina L., Lettori postumi di Atanasio: il patriarca Fozio e Ognibene da Lonigo, „Rivista di Storia del Cristianesimo” 8 (2011) 125-135.

D'Antiga R., Il testo autentico della traslazione di Sant'Atanasio nel monastero della S. Croce a Venezia, „Benedictina” 58 (2011) 307-324.

DelCogliano M., The influence of Athanasius and the Homoiousians on Basil of Caesarea's decentralization of ,, Unbegotten”, JECS 19 (2011) 197-223.

Dîncă L., Conveniența expresiilor dogmatice prezente în Simbolul de la Niceea, ,consubstanțial Tatălui' şi , din substanțta Tatălui', în scrierile Sf. Atanasie cel Mare, „Revista Ecumenică Sibiu” 3 (2011) nr 1, 55-76.

Dîncă L., Saint Athanase d'Alexandrie sur la procession de l'Esprit Saint, „Adversus Haereseis" 4 (2011) 588-601.

Fernández T., Dos fragmentos inéditos de Atanasio de Alejandría, „Erytheia” 32 (2011) 79-93. 
Hiestand G.L., Not „just forgiven”: how Athanasius overcomes the under-realised eschatology of evangelicalism, ,The Evangelical Quarterly” 84 (2012) 47-66.

Maftei E., A fost Sfântul Atanasie apolinarist?, „Studi Teologice”, 2011, nr 2, $107-$ 123.

Ritter A.M., Athanasius as Trinitarian Theologian, StPatr 52 (2011) 101-111.

Sumner D.O.,The Instrumentalization of Christ's Human Nature in Athanasius of Alexandria, StPatr 52 (2011) 129-138.

Tanaka H., Athanasius as interpreter of the Psalms. His Letter to Marcellinus, „Pro Ecclesia" 21 (2012) 422-447.

Vinzent M., Direct of Discrete - On Inter-textuality and Counter-textuality in Athanasius, ,, Orations against the Arians” I-III, StPatr 52 (2011) 113-127.

\section{Atenagoras}

Velasco Delgado A., Atenágoras de Atenas. Aproximación a su cultura, „Escritos del Vedat" 42 (2012) 61-110.

\section{Augustyn}

--, Sermo sancti Augustini „De eleemosyna”: (Haffner 1 und Etaix $3=350$ B-C). Kritische Edition, Übersetzung und Kommentar H. Drobner, „Augustinianum” 52 (2012) 257-297.

Adămuț A., Despre cum că anima naturaliter christiana (sau despre „De catechizandis rudibus”), „Classica \& Christiana” 7 (2012) 17-28.

Adkin N., ,Labor tam utilis ”. Sallust in Augustine on the Vulgate, „Augustiniana” 61 (2011) 49-53.

Aguayo E., Aproximación al conocimiento de la Santísima Trinidad, según San Agustín, „Anámnesis” 21 (2011) nr 41, 51-74.

Albinus L., Spejlets gåde. Strukturelle offilosofiske aspekteri Augustins ,, Bekendelser”, „Dansk Teologisk Tidsskrift” 74 (2011) 116-135.

Alonso López M., El cuidado en la teología de San Agustín, RevA 52 (2011) 373416.

Andoková M., Tolera infirmitatem, si desideras perfectionem: The Notion of „tolerantia” in Relation to Christian Perfection in Augustine's ,, Sermones ad populum”, StPatr 51 (2011) 115-132.

Andrews J.A., Relevant Augustine: What „De doctrina christiana” Says Today, StPatr 50 (2011) 309-320.

Barucco E., „Il Sermone del Signore sulla montagna”. Una visione mistica della morale cristiana: Agostino, Tommaso d'Aquino, Beato Angelico, S. Pinckaers, „Teresianum” 63 (2012) 109-130.

Benavides G.V., San Agustín y la doctrina de la creación: Reflexiones sobre sus respuestas a algunas objeciones maniqueas y neoplatónicas, „Cuadernos Monasticos" 47 (2012) nr 180, 39-56.

Bendimez Equiarte E.A., El „,Viscum ” y las alas del alma en San Agustín. Aplicaciones espirituales de una forma rudimentaria de cacería, RevA 52 (2011) 283-304.

Boersma G.P., ,, Exquisite and precious vessels ”: , Doctrina” in Book 1 of Augustine's „,Confessions”, 61 (2011) 187-205.

Bergstrom J.W., Charity as Equity in the Hermeneutics of Augustine's „De doctrina christiana", StPatr 52 (2011) 199-210. 
Boodts Sh., A new critical edition of Augustine's „, Sermo 170”: with a tentative analysis of the stemmatic position of the „De lapsu mundi” collection, SE 50 (2011) 185-225.

Brito Martins M.M., Unde malum: O mal em Santo Agostinho, „Theologica” 47 (2012) 541-562.

Brotóns Tena E.J., Cuando Dios sale a nuestro encuentro: la existencial cristología de san Agustín, „Estudios Trinitarios” 45 (2011) 49-114.

Buch L., La explosión de la postmodernidad: en torno a „La leyenda del pianista del océano”, de G. Tornatore, „Mayéutica” 38 (2012) 51-64.

Bulletin augustinien pour 2010/2011 et compléments d'années antérieures., REAug 57 (2011) 429-491.

Burke C., St. Augustine a view on marriage and sexuality in today's world, Angelicum" 89 (2012) 377-404.

Burrus V., ,, Fleeing the uxorious kingdom”. Augustine's queer theology of marriage, JECS 19 (2011) 1-20.

Campos Ortega P., Del „, Camino nuevo a la Ciudad de Dios” cinco siglos de filosofía cristiana, RevA 52 (2011) 417-450.

Cassingena-Trévedy F., ,Inardescimus et imus” (Conf. XIII, 9, 10). Les „, Confessions” d'Augustin ou le feu converti, RechAug 36 (2011) 139-194.

Catalano Ch., Dai pelagiani ai recentiores: l'affaire du plagiaire (Garasse) nell'Augustinus e nella corrispondenza di Cornelis Jansen, „Augustiniana” 62 (2012) 153-188.

Catarinella F.M., Forme della polemica antipagana nell'Epistolario di Agostino, „Auctores Nostri” 9 (2011) 411-426.

Cattani P., Les écrivains français convertis au catholicisme lecteurs de saint Augustin: un augustinisme du début du XXe siècle?, RSLR 48 (2012) 99-116.

Cattani P., Saint Augustin entre Papini et Prezzolini, RSLR 48 (2012) 353-374.

Chávez Aguilar P., ,,De urbis excidio” de San Agustín: razón y revelación en la comprensión de un acontecimiento histórico, TyV 52 (2011) 245-252.

Cillerai B., Agustín y la memoria: formas de recuerdo en la ,vita beata”, „Augustinus” 57 (2012) 23-41.

Cipriani N., Agustín lector de los comentarios paulinos de Mario Victorino, „Augustinus” 56 (2011) 425-441.

Cipriani N., El autor de los textos pseudobasilianos reproducidos en C. Iul. 1, 1617, y la polémica antiagustiniana de Juliano de Eclana, „Augustinus” 56 (2011) 285-295.

Cipriani N., El misterio trinitario en los Padres, „Augustinus” 57 (2012) 413-434.

Cipriani N., La „retractatio” agustiniana, sobre la procesión-generación del Espíritu Santo (Trin. 5,13), „Augustinus” 57 (2012) 339-347.

Cipriani N., La autonomía de la voluntad humana en el acto de fé: las razones de una teoría acogida primero y rechazada después por San Agustín, „Augustinus” 57 (2012) 281-293.

Cipriani N., La doctrina del pecado original en los escritos de san Agustín hasta el „Ad Simplicianum”, „Augustinus” 57 (2012) 331-338.

Cipriani N., La inspiración tertuliana en el „De libero arbitrio” de san Agustín, „Augustinus” 56 (2011) 369-383. 
Cipriani N., La preceptiva antigua y la Regla monástica de san Agustín, „Augustinus” 56 (2011) 443-457.

Cipriani N., La presencia de Mario Victorino en la reflexión trinitaria de san Agustín, „Augustinus” 56 (2011) 459-511.

Cipriani N., La revelación de la Trinidad inmanente en los „,Tractatus in Iohannem” de san Agustín, „Augustinus” 57 (2012) 371-381.

Cipriani N., La violencia en el pensamiento de san Agustín, „Augustinus” 57 (2012) 349-370.

Cipriani N., Las fuentes cristianas de la doctrina trinitaria en los primeros Diálogos de san Agustín, „Augustinus” 56 (2011) 311-368.

Cipriani N., Las obras de san Ambrosio en los escritos de san Agustín anteriores al episcopado, „Augustinus” 56 (2011) 385-424.

Cipriani N., Revelación cristiana y verdad en san Agustín. A propósito de un ensayo reciente, „Augustinus” 57 (2012) 383-411.

Cipriani N., San Agustín en la reflexión teológica de J. Ratzinger, „Augustinus” 57 (2012) 437-448.

Clariond Domene B., San Agustín y los donatistas, „Ecclesia” 2011, nr 4, 473-484.

Cocchini F., Notas sobre la „Inchoata expositio ad Romanos ”de Agustín, „Augustinus” 56 (2011) 39-44.

Colli A., Intellectus agens als abditum mentis. Die Rezeption des Augustins in der Intellekttheorie Dietrichs von Freiberg, ThPh 86 (2011) 360-371.

Coutinho J., Trilogias agostinianas. Tríades e dinâmica ternária em santo Agostinho, „Theologica” 47 (2012) 497-508.

Coyne R., A difficult proximity. The figure of Augustine in Heidegger's path, „The Journal of Religion" 91 (2011) 365-396.

Cuadros J.D.R., Frente a herejías y sociedades en decadencia: análisis comparativo de los modelos eclesiales en Ireneo de Lyon y Agustín de Hipona, „Reflexiones Teológicas" 7 (2011) 123-154.

Cutino M., L'auteur du De providentia Dei et un mystérieux calomniateur d'Augustin. Pour une interprétation de deux épigrammes polémiques de Prosper d'Aquitaine, RevSR 86 (2012) 307-342.

Cutino M., L'auteur du De providentia Dei et un mystérieux calomniateur d'Augustin. Pour une interprétation de deux épigrammes polémiques de Prosper d'Aquitaine, RevSR 86 (2012) 307-342.

D'Acunto G., La trinità della parola in Agostino, „Miscellanea Franciscana” 112 (2012) 619-632.

D'Andrea B., Pastoral y acompañamiento vocacional para la vida consagrada agustino-recoleta (en tiempos de revitalización), „Mayéutica” 38 (2012) 315-338.

Dalmon L., La correspondencia antipelagiana de África con Roma: presentación de un expediente del epistolario agustiniano (416-418), „Augustinus” 56 (2011) 45-51.

De Luis Vizcaíno P., Dimensión trinitaria de la oración en San Agustín, „Estudios Trinitarios" 46 (2012) 63-103.

De Luis Vizcaíno P., El quiasmo en el „Praeceptum” de san Agustín (I), EstA 47 (2012) 427-448.

De Luis Vizcaíno P., La Trinidad en la oración, según S. Agustín, EstA 47 (2012) 5-22. 
De Luis Vizcaíno P., Las crisis sacerdotales de San Agustín, EstA 46 (2011) 5-32.

De Luis Vizcaíno P., Presencia de la carta 22 de san Jerónimo en el Praeceptum de san Agustín, EstA 46 (2011) 203-231.

De Mattos J.R.A., Ética Agostiniana, „Revista de cultura teológica” 19 (2011) nr 73, 117-127.

De Paula S.P., „Os tempos somos nos” historia, memória e tempo nos sermoes de santo Agostinho, „Mayéutica” 37 (2011) 67-103.

Della Serra M., Note sull 'onnipotenza divina nell'opera di Agostino, „Augustinianum” 51 (2011) 147-160.

Delmulle J., Gratia Adami, gratia Christi. La nature, la Loi et la grâce dans le premier augustinisme, RHR 229 (2012) 193-214.

Descotes P., La notion de ,, Testament” chez saint Augustin, RHR 229 (2012) 167-191.

Dorfbauer L.J., „Commendaciones Augustini”: Textsammlungen zum Lob des Augustinus aus dem Umfeld des Augustinereremitenordens. Mit einer Edition von Pseudepigrapha, „Augustiniana” 61 (2011) 271-333.

Dunn G.D., Funciones de María, según las homilías navideñas de Agustín de Hipona, „Augustinus" 56 (2011) 53-67.

Dunn G.D., La pobreza como asunto social en las homilias de Agustín, „Augustinus” 57 (2012) 42-48.

Dupont A., Augustine's exegesis of Rom 1:17 and 4:5. Continuity in Augustine's combination of Iustitia, Fides and Gratia?, „Adamantius” 18 (2012) 233-250.

Dupont A., Augustine's exegesis of 1Tim 1,15-16 and Rom 6,12-13. A specific use of the scriptures within the anti-Pelagian sermones, ZNW 102 (2011) 130-148.

Dupont A., Augustine's exegesis of Lk. 18,1-7. A pastoral approach to a doctrinal issue?, RB 118 (2011) 130-134.

Dupont A., The presence and treatment of ,, gratia ” in Augustine's ,, Sermones ad populum" on the liturgical feast of Pentecost: Do anti-Donatist and anti-Pelagian polemics influence Augustine's preaching?, „Antiquité Tardive” 20 (2012) 217-240.

Eelen A., Augustine and Phil. 3, 3-16: one Bible fragment, several exegetical approaches, SE 50 (2011) 227-263.

Eguiarte Bendímez E., Agustín y el „,poculum oblivionem praestans”, „Augustinus” 56 (2011) 69-74.

Eguiarte Bendímez E.A., Coloquio internacional sobre los sermones de san Agustín, en Roma, „Augustinus” 57 (2012) 5-22.

Eguiarte Bendímez E.A., El don de creer y padecer por Cristo. San Agustín y algunos sermones sobre mártires, „Mayéutica” 38 (2012) 439-456.

Eguiarte Bendímez E.A., Exégesis agustiniana en los libros XVI y XVII del „,De civitate Dei”, ,Mayéutica” 38 (2012) 111-152.

Eguiarte Bendímez E.A., La inspiración de la Sagrada Escritura en las „,Enarrationes in Psalmos” de San Agustín, „Mayéutica” 38 (2012) 357-398.

Eguiarte Bendímez E.A., Los espectáculos del anfiteatro en san Agustín y sus implicaciones espirituales, „Augustinus” 57 (2012) 75-97.

Eguiarte Bendímez E.A., Reestructuración y revitalización en San Agustín. Algunos apuntes, „Mayéutica” 37 (2011) 245-284.

Eguiarte Bendímez E.A., San Agustín y la solidaridad, „Mayéutica” 38 (2012) 19-50. Eguiarte Bendímez E.A., Una invitación a creer: el „De utilitate credendi” de San Agustín, „Mayéutica” 38 (2012) 261-313. 
Ehrlich D., Some further reflections regarding the Talbott-Crisp debate on the Augustinian concept of everlasting punishment, ,Religious Studies” 47 (2011) 23-40.

Elgersma Helleman W., „Cristo, la Sabiduría de Dios”. La lógica de atribución en „De Trinitate” 5-7 de Agustín, „Augustinus” 56 (2011) 75-81.

Ellingsen M., Augustinian origins of the Reformation reconsidered, SJT 64 (2011) 13-28.

Ferlisi G., Indagine sulla materia informe. Guida alla letteratura della „, Confessioni”, „Presenza Agostiniana” 38 (2012) nr 4, 6-12.

Fernández Noriega R., San Agustín, inspirador de los voluntarios: notaciones en El Año Internacional del Voluntariado, RevA 52 (2011) 687-686.

Ferrari L.C., La pasión del joven Agustín por la filosofia, „Mayéutica” 38 (2012) 77-102.

Ferri R., Il „De Trinitate” di Agostino d'Ippona. Commento al libro primo, „Lateranum” 78 (2012) 549-570.

Ferrisi P.A., Creazione dal nulla esegesi metafisica di Agostino a Gen. 1,1-2, „Augustinianum” 51 (2011) 123-146.

Fischer N., Kants Verhältnis zum christlichen Glauben, ThG 102 (2012) 25-44.

Fladerer L., Importancia de la metonimia en la interpretación agustiniana del relato de la creación, „Augustinus” 56 (2011) 91-96; 57 (2012) 99-104.

Foley M.P., Casiciaco y el denominado ,,giro al sujeto”, „Augustinus” 56 (2011) 97-106.

Folliet G., De la citation scripturaire „Initium/principium sapientiae timor Domini” à l'adage „La crainte est le commencement de la sagesse”, RechAug 36 (2011) 1-88.

Franchi R., Lucrezia, Agostino e i retori, „Latomus” 71 (2012) 1088-1101.

Francis B.J., The Resurrrection of the Body and St. Augustine, „Indian Theological Studies" 49 (2012) nr 2, 59-70.

Ganze R., The Individual in the Afterlife: Theological and Sociopolitical Concerns in King Alfred's Translation of Augustine's ,,Soliloquies”, ,Studia Neophilologica” 83 (2011) 21-40.

Garcia Alvarez J., Le «ministère de la charité» à l'égard des pauvres selon s. Augustin, CPE 2012, nr 127, 19-34.

Garcia Alvarez J., Marie, vierge, mère et modèle de l'Église selon S. Augustin, CPE 2011, nr 121, 8-26.

García E.G., „Belleza siempre antigua y siempre nueva ...”. El carisma, factor de revitalización, „Mayéutica” 38 (2012) 399-438.

Garcia R.M., Agustín ¿es „augustinista” en política?, RevA 52 (2011) 305-328.

Garhammer E., Von Augustinus lernen. Eine überraschende Entdeckung zur Predigttätigkeit von Laien, „Stimmen der Zeit” 230 (2012) 3-11.

Gómez F.M., ,,Sursum cor”. Itinerario agustiniano para la formación de orantes, „Mayéutica” 37 (2011) 323-372.

Gorman R.F., St. Augustine, the Psalms and beatitudinal love, „Homiletic and Pastoral Review" 111 (2011) nr 5, 6-13.

Grossi V., Nota all'introduzione di una recente traduzione del „De civitate Dei”, „Augustinianum” 52 (2012) 467-486.

Grote A.E.J., No había „scriptorium” en el monasterio de Cartago?: observaciones sobre escritura y trabajo manual en „De opere monachorum” de Agustín, „Augustinus” 56 (2011) 107-113. 
Guevin B.M., „Saulo, Saulo, por qué me persigues?”. Hch 9, 4 en las „Enarrationes in Psalmos” de Agustín, „Augustinus” 56 (2011) 115-122.

Jacobitz G., The epistolary correspondence of Saints Jerome and Augustine and the expansion of the ,Rule” of Saint Benedict from 66 to 73 chapters, ABR 63 ( 2012) 384-418.

Harmon Th.P., Reconsidering Charles Taylor's Augustine, „Pro Ecclesia” 20 (2011) 185-209.

Humphries Th., ,, These words are spirit and life”. Thomas' use of Augustine on the Eucharist in ,Summa theologiae”, III,73-83, „Recherches de Théologie et Philosophie Médiévales" 78 (2011) 59-96.

Kamimura N., La exégesis bíblica de Agustín en „,De Genesi ad litteram liber unus imperfectus”, „Augustinus” 57 (2012) 137-142.

Kellenberger E., Augustin und die Menschen mit einer geistigen Behinderung. Der Theologe als Beobachter und Herausgeforderter, ThZ 67 (2011) 25-36.

Kilby M., Augustine of Hippo on the Bishop as Spiritual Father, StPatr 52 (2011) 235-245.

Koch K., Von Gott geliebt werden und selbst lieben. Der Heilige Augustinus als demütiger Exeget des christlichen Kerngeheimnisses, „Theologische Beiträge” 42 (2011) 337-341.

König-Pralong C., Corps rêvés et corps internaux. Le sommeil d'Augustin, „Revue de théologie et de philosophie" 143 (2011) 145-160.

Kotsko A., Gift and communio. The Holy Spirit in Augustine's „,De Trinitate”, SJT 64 (2011) 1-12.

Lagouanere J., Image de Dieu et intériorité humaine selon S. Augustin, CPE 2012, nr 128, 50-61.

Lamberigts M., Augustine on marriage. A comparison of „De bono coniugali” and „De nuptiis et concupiscentia”, „Louvain Studies” 35 (2011) nr 2, 32-52.

Lamberigts M., Gerusalemme e Babilonia. La dottrina agostiniana delle due città nel suo contesto, „Concilium” (IT) 47 (2011) 123-135.

Lamberigts M., Jerusalem and Babylon: Augustine's Two Cities in Contex, „Concilium” (ENG) 47 (2011) 71-81.

Lamberigts M., Jerusalem und Babylon. Die Lehre des Augustinus von den zwei Städten in ihrem Kontext, „Concilium” (GER) 47 (2011) 536-545.

Lamelas I.P., $A$, invenção” do pecado original segundo Agostinho, „Didaskalia” 42 (2012) 55-134.

LeBrun J., L'antiaugustinisme de Richard Simon, RHR 229 (2012) 257-273.

Lee G.W., Republics and their loves. Rereading „, City of God” 19, „Modern theology" 27 (2011) 553-581.

Lienhard J. T., Agustín y el „Filioque”, „Augustinus” 56 (2011) 131-144.

Lomiento V., Le forme della polemica fra il manicheo Secondino e Agostino, „Auctores Nostri" 9 (2011) 491-506.

MacCurry J.M., To love the world most deeply. The phenomenology of the world as gift in Augustine's ,, Confessions”, „New Blackfriars” 92 (2011) nr 1037, 46-54.

Magnavacca S., Los términos ,os-pectus-cor” en „, Confesiones”, VI, „Studium” 14 (2011) 145-158.

Malatesta M., Filologia e logica utilità della logica come strumento complementare della filologia: il caso di sant'Agostino, „Augustinianum” 52 (2012) 299-338. 
Marin M., Forme della polemica agostiniana: contro Cresconio, grammatico donatista, „Auctores Nostri” 9 (2011) 507-542.

Martínez T.M. - Miñambres M.A.V., Parangones de eclesiología agustiniana, RelCat 2011, nr 259, 699-728.

Mayer C., Augustinus: ,,Ich will, dass Du bist” (?): zum Problem der angeblich augustinischen Herkunft dieser Sentenz, „Augustiniana” 62 (2012) 251-264.

Mazaheri J.H., Calvin and Augustine's Interpretations of ,"The father in heaven”, RHE 106 (2011) 440-451.

McWilliam J., La cristología de las „Enarrationes” de 392 sobre los salmos, „Augustinus” 56 (2011) 145-151.

Merdinger J.E., Conversaciones y peregrinaciones de Agustín con sus amigos más intimos, „Augustinus” 56 (2011) 153-158.

Merkt A., „Amt der Tradition” und „Charisma der Wahrheit”. Die theologische Bedeutung der apostolischen Sukzession bei Irenäus von Lyon und Augustinus, „Internationale katholische Zeitschrift „Communio” 40 (2011) 221-233.

Miller R.B., Evil, friendship, and iconic realism in Augustine's „, Confessions ”, HTR 104 (2011) 387-409.

Miñambres M.A.V., La interioridad agustiniana: camino de la felicidad, RelCat 2011, nr 257-258, 341-364.

Miscioscia S., Bonum e malum a confroto nell'Epistolario di Agostino d'Ippona, „Ciudad de Dios” 224 (2011) 53-78, 341-171.

Miscioscia S., Bonum/malum per una vita bona honesta nella res publica. Una interessante rilettura dell'Epistolario di Agostino d'Ippona, „Ciudad de Dios” 224 (2011) 619-648.

Molteni A., La Iglesia en el mundo según el „, De civitate Dei” de San Agustín, „Anales de Teologia" 13 (2011) 7-39.

Moore D., Truth and image in Augustinian epistemology, „Augustiniana” 61 (2011) $11-48$.

Morán Fernández J., Colaborando a una Bibliografía de san Agustín III (1925-1945), EstA 46 (2011) 341-375.

Morillo Rey P.A., El papel de la filosofía en los diálogos de Casicíaco, „Isidorianum” 21 (2012) 9-38.

Morillo Rey P.A., Posibles rasgos neoplatónicos en la experiencia agustiniana de Ostia, „Isidorianum” 20 (2011) 37-48.

Morillo Rey P.A., San Agustín de Hipona: Místico desconocido, „Isidorianum” 19 (2010) rok wyd. 2012, 501-504.

Morillo Rey P.A., San Agustín. Motivo para el año de la Fe, „Isidorianum” 21 (2012) 241-276.

Mowbray A., Augustine, the semi-Pelagian, „Augustiniana” 62 (2012) 189-249.

Neumann De Paulo C.J. - Messina P., La influencia de Agustín de Hipona en el desarrollo de la teoría cristiana de la guerra justa, „Augustinus” 57 (2012) 144-167.

Neumann De Paulo C.J. - Rudnytzky L., A quién le pertenece el amor?: una genealogía del eros y la cuestión de Agustín en la teología católica contemporánea, „Mayéutica” 38 (2012) 65-76.

Nugent P., Patrística y pedagogía: Jerónimo y Agustín, „Augustinus” 56 (2011) 159164. 
Paletta J., The ,ordo sapientiae”. Augustine's program for philosophical study in his early works, „Augustiniana” 61 (2011) 55-74.

Paletta J., The theme of ontological dependence in „, Confessions” book 7 chapters 14-20, „Augustiniana” 61 (2011) 207-223.

Partoens G., An ant-Donatist sermon on fasting: Augustine's „De utilitate ieiunii”: a critical edition with philological introduction, SE 51 (2012) 151-194.

Pasquetto V., La figura di Cristo come „Parola di Dio fattasi carne” nel „, Commento di S. Agostino al Vangelo e alla Prima Lettera di Giovanni ” (II, III), „,Teresianum” 62 (2011) 7-39; 409-444; 63 (2012) 5-38.

Patout Burns J., Baptism as dying and rising with Christ in the teaching of Augustine, JECS 20 (2012) 407-438.

Pegoraro J.A., San Agustín y el concepto Ciceroniano de República, „ETIAM” 6 (2011) 223-230.

Pereira-Lamelas I., „,Hominis sapientia pietas est”. Santo Agostinho e a conversao da pietas, „Theologica” 47 (2012) 455-472.

Petit G., Le geste du Christ serviteur. L'interprétation augustinienne du lavement des pieds (Jn 13, 20), CPE 2012, nr 127, 35-46.

Pierantoni C., El verbum cordis formabile agustiniano y la imagen trinitaria en el hombre, TyV 52 (2011) 197-210.

Pons Pons G., El martirio y la gloria de San Lorenzo en los Sermones de San Agustín y San Máximo, „La Ciudad de Dios” 224 (2011) 283-297.

Pons Pons G., La Egloga IV de Virgilio y san Agustín, RevA 52 (2011) 747-774.

Remy G., La notion de „medietas” chez Saint Augustin, RevSR 85 (2011) 211-229.

Renczes Ph.G., L',,interiorità” agostiniana. Un concetto dualistico?, „Rassegna di Teologia" 52 (2011) 61-82.

Rombs R., ,Vinculum pacis”: Ef 4, 3 en la pneumatología de Agustín, „Augustinus” 56 (2011) 175-182.

Rombs R.J., ,, Vinculum pacis”: Eph. 4:3 and Indications of a Pneumatology in St. Augustine's Theology, StPatr 50 (2011) 321-327.

Rose P., Cohesión textual en „De cura pro mortius gerenda” de Agustín, „Augustinus” 56 (2011) 183-189.

Rosenberg S.P., Oralidad, textualidad y la memoria de los feligreses, en los sermones de Agustín, „Augustinus” 57 (2012) 169-175.

Rossi M.A., El pasaje del sujeto antiguo al sujeto medieval y sus implicaciones politicas: Aristótoles y Agustín de Hipona, „ETIAM” 6 (2011) 47-68.

Saeteros Pérez T., Mónica de Thagaste, Madre y „Maestra” de Agustín de Hipona, „La Ciudad de Dios” 224 (2011) 583-617.

Sánchez Rojas G., ,Intellige ut credas. Crede ut intelligas”. Reflexiones sobre la fé y la teología en San Agustín de Hipona, ,Revista Teológica Limense” 2012, nr 1, 5-22.

Schockenhoff E., Der lange Schatten des Augustinus. Oder: was heißt menschenwürdige Sexualität?, „Communio” 41 (2012) 197-212.

Seewald M. - Stubenrauch B., Freiheit-ein Modewort der Theologie? Systematische Klärungsversuche im Anschluss an Augustinus und Maximus Confessor, „Communio” 40 (2011) 381-395.

Sfameni Gasparro G., Sacramentum regis bonum est abscondere (Agostino, „Epist.” 237, 4): misteri della Scrittura, vera scienza spirituale e dissimulatio in Priscilliano 
e nel Priscillianesimo, „Annali di Scienze Religiose” 4 (2011) 111-155.

Sguazzardo P., Unità e Trinità in Dio secondo Agostino d'Ippona, „PATH” 11 (2012) 327-345.

Smalbrugge M., La belleza y la gracia en Agustín, „Augustinus” 56 (2011) „Augustinus” 56 (2011) 191-197.

Smith J.K., Formation, grace, and pneumatology. Or, where's the spirit in Gregory's Augustine?, „Journal of religious ethics” 39 (2011) 556-569.

Steinhauser K.B., Virgilio, Cicerón y el ,rusticanus ”. „Acad”.3, 34-35, „Augustinus” 56 (2011) 199-204.

Stepinova M., Aquinas'solution of Aristotle's incontinent man and Augustine's two wills, „New Blackfriars” 92 (2011) nr 1039, 322-340.

Stevenson K., Patristics and bishops. What four Fathers might say about episcopacy today, ,Theology” 114 (2011) 91-100.

Sullivan F.A., The development of doctrine about infants who die unbaptized, ,Theological Studies” 72 (2011) 3-14.

Sun S., Fate and will: Augustine's revaluation of Stoic fate in the „De civitate Dei” V, 8-11: Augustine's revaluation of Stoic fate in the „De civitate Dei” $V, 8-11$, „Mediaevistik” 25 (2012) 35-54.

Svensson M., Fe y razón en el campo práctico-político. Un estudio desde la correspondencia de san Agustín con autoridades públicas, TyV 52 (2011) 229-244.

Ticciati S., A Performative Reading of Augustine's Doctrine of Predestination, StPatr 52 (2011) 211-234.

Tkacz M.W., Agustín, el „,Timeo” y la falacia cosmogónica, „Augustinus” 56 (2011) 205-212.

Toom T., Agustín aprende a expresarse: „, Confesiones” 1, 13, „Augustinus” 56 (2011) 214-218.

Topping R., Cristo, ,, disciplina Dei” en el pensamiento temprano de Agustín sobre educación, „Augustinus” 57 (2012) 193-198.

Troiani L., Alcune riflessioni sopra il libro XVIII della Città di Dio, „Athenaeum” 100 (2012) 373-384.

Troup C.L., Augustine. Bishop of intellectuals, „Listening” 46 (2011) 69-79.

Van Egmond B., Augustine's use of the concept of „Praevaricatio”: a case in the recent debate on continuity in Augustine's doctrine of grace, SE 51 (2012) 195-214.

Van Reisen H., La elocuencia de la palabra, „Augustinus” 57 (2012) 199-208.

Van Reisen H., La tierra como el cielo? San Agustín sobre el Padre Nuestro, „Mayéutica” 38 (2012) 339-355.

Van Reisen H., San Ambrosio y San Agustín sobre la negación de Pedro, „Mayéutica” 37 (2011) 373-384.

Van Reisen H., Una palabra de sanación: San Agustín sobre la salud, „Mayéutica” 38 (2012) 5-17.

Vannier M.A., Augustin, CPE 2011, nr 124, 42-44.

Vannier M.A., La dialectique de l'image de Dieu chez S. Augustin, CPE 2012, nr 128, 39-49.

Vannier M.A., Luz e iluminación en Agustín: relectura de una cuestión ya antigua, „Augustinus” 56 (2011) 220-226.

Velásquez O., La Ciudad de Dios desde la perspectiva de la razón: la cuarta politeia de la antigüedad, TyV 52 (2011) 211-228. 
Verdú Berganza I., La humildad y el acceso a la verdad en el pensamiento de Agustín de Hipona, „Cauriensia” 7 (2012) 385-395.

Veronese M., Agostino contro i priscillianisti Manichaeorum simillimi, „Auctores Nostri" 9 (2011) 543-572.

Von Der Osten D.E., Felicidad perpetua: sermones de Agustín sobre el martirio femenino (s. 280-282 aumentado = Erfurt 1), „Augustinus” 56 (2011) 83-90.

Von Seele P.F., Von der Vertrauenskrise zur Misstrauenskrise. Erklärungen mit Augustin zur Glaubwürdigkeit und Ethik staatlicher Rettungspakete, ,Zeitschrift für evangelische Ethik" 55 (2011) 36-48.

Von Sieben H.J., Augustinus zum Thema ,Ruhe” unter Berücksichtigung der Termini quies und requies. Ein chronologischer und systematischer Überblick, ThPh 87 (2012) 161-192.

Vorster N., The Augustinian type of theodicy. Is it outdated?, „Journal of Reformed Theology" 5 (2011) 26-48.

Weber D., Observaciones sobre „Locutiones in Heptateuchum” de Agustín, „Augustinus” 56 (2011) 227-233.

Wierenga E.R., Augustinian perfect being theology and the God of Abraham, Isaac, and Jacob, ,International Journal for Philosophy of Religion” 69 (2011) 139-151.

Wilkins J.D., Why Two divine Missions? Development in Augustine, Aquinas, and Lonergan, ITQ 77 (2012) 37-66.

Wu T., Augustine on ,, initium fidei”. A case study of the coexistence of operative grace and free decision of the will, „Recherches de théologie et philosophie médiévales” 79 (2012) 1-38.

Yin Yam Ch. - Dupont A., A mind-centered approach of imago Dei: a dynamic construction in Augustine's ,,De Trinitate” XIV, „Augustiniana” 62 (2012) 7-43.

Yin Yam Ch. - Dupont A., The role of imago Dei in Augustine's Speaking of Trinity: a study of Neglected Book XV „De Trinitate”, ,La Ciudad de Dios” 225 (2012) 325-359.

Yudin V., Porphyry against the Resurrection in Augustine, StPatr 50 (2011) 301-307.

\section{Augustyn Pseudo-}

Dorfbauer L.J., Eine Untersuchung des pseudoaugustinischen „,Dialogus quaestionum" (CPPM 2A, 151), RBen 121 (2011) 241-315.

\section{Auzoniusz Pseudo-}

D’Angelo R.M., Il motivo degli odia fraterna in una rielaborazione tardoantica: Epigr. Bob. 52 Sp. = Ps.Auson. 25 p.431P, „Bollettino di Studi Latini” 42 (2012) 535-545.

\section{Bardesanes z Edessy}

Biffi N., Ciò che Bardesane venne a sapere sull'India, „Classica \& Christiana” 6 (2011) 305-226.

Possekel U., Bardaisan and Origen on Fate and the Power of the Stars, JECS 20 (2012) 515-541.

\section{Bazyli Wielki}

--, Lettre aux évêques d'Italie et de Gaule, sur l'état des Églises, POC 61 (2011) nr 4, 227-228. 
Ballan J., Basil of Caesarea on the ascetic craft. The invention of ascetic community and the spiritualization of work in the asketikon, „The Heythrop Journal” 52 (2011) 559-568.

Bamberger J.E. - Baudry É., Mémoire et disposition profonde: mnèmè - diathesis; les dynamismes psychiques dans la théologie ascétique de Saint Basile le Grand, CCist 74 (20120 258-281.

Baudry P.E., S. Basile. L'ordre des questions ascétiques dans les manuscrits d'Orient, SMon 53 (2011) 53-75.

Baudry P.E., S. Basile. Prologue des Grandes Règles: Essai de structure, SMon 53 (2011) 21-52.

Bezarashvili K. - Otkhmezuri T., Education and Scholarship in Byzantium: the Byzantine Manuscript (Cod. Tbilis. Gr. 48) containing Works of Basil of Caesarea, „Adamantius” 17 (2011) 220-237.

Capboscq A., Notas sobre la magnanimidad de Dios, según Basilio de Cesarea, „Cuadernos Monasticos” 46 (2011) nr 177, 151-164.

DelCogliano M., Basil of Caesareas's homily „, On not three Gods” (CPG 2914), SE 50 (2011) 87-132.

DelCogliano M., Origen and Basil of Caesarea on the liar paradox, „Augustinianum” 51 (2011) 349-365.

DelCogliano M., The influence of Athanasius and the Homoiousians on Basil of Caesarea's decentralization of ,,Unbegotten”, JECS 19 (2011) 197-223.

DelCogliano M., Tradition and polemic in Basil of Caesarea's homily on thr theophany, VigCh 66 (2012) 30-55.

Gain B., Un évêque novateur en Cappadoce saint Basile et la Basiliade, CPE 2012, nr 127, 5-18.

Holman S.R. - Macé C. - Matz B.J., „De beneficentia”: a homily on social action attributed to Basil of Caesarea, VigCh 66 (2012) 457-481.

Morales X., Quarante ans après: la psychologie dynamique de Basile de Césarée, CCist 74 (2012) 282-288.

Palumbo S., La polemica ,in divites” di Ambrogio e le omelie VI e VII di Basilio, „Auctores Nostri” 9 (2011) 369-386.

Sandwell I., How to teach Genesis 1.1-19: John Chrysostom and Basil of Caesarea on the creation of the world, JECS 19 (2011) 539-564.

Silvas A., The Latin „Regula Basili” and the Syriac „, Questions of the brothers”: a preliminary enquiry, ParOr 36 (2011) 445-452.

Van Parys M., Communion et solitude selon saint Basile de Césarée, „Irénikon” 84 (2011) 5-32.

\section{Bazyli z Seleucji}

Vannier M.A., Basil de Séleucie, CPE 2011, nr 124, 45-46.

\section{Benedykt}

Casey M., Un décalogue bénédictin, CCist 73 (2011) 305-320; 386-403.

Cerezo M.M., La figura del abad en el monacato benedictino, „Liturgia y Espiritualidad" 43 (2012) 35-43.

De Vogüé A., The „, Rule of the Master ” and the „Rule” of Saint Benedict in relation to the first monasteries of Subiaco, ABR 63 (2012) 36-48. 
Heisey D.J., Benedict of Nursia in the writings of Hans Urs von Balthasar, SMon 54 (2012) 389-400.

Heisey D.J., Daniel Boorstin and Saint Benedict: an American historian's perspective on the holy rule, ABR 62 (2011) 278-290.

Henry P., La vida benedictina: una escuela de humanidad, „Revista Clar” 49, (2011) nr 1, 106-116.

Jacobitz G., The epistolary correspondence of Saints Jerome and Augustine and the expansion of the ,Rule” of Saint Benedict from 66 to 73 chapters, ABR 63 ( 2012) 384-418.

Molinier J.L., Regula monastica et institution monastique: enjeux herméneutiques et institutionnels du recours à la $R B$, CCist 73 (2011) 187-188.

Motas Mosquera P., Capítulo II de la Regla benedictina: el abad: comentario crítico y actual, NV 35 (2011) 201-207.

Ouellette P. - Synder P. - Carette R., L’application de la spiritualité bénedictine au loisir des personnes âgées: un modèle théorique du bonheur spirituel, „Studies in religion" 40 (2011) 21-44.

Pearson P.M., Hospitality to the stranger: Thomas Merton and St. Benedict's exhortation to welcome the stranger as Christ, ABR 62 (2011) 27-41.

Posa C., Discretio: Heloise of the Paraclete's embodied reading of the „Rule” of Benedict, ABR 62 (2011) 161-187.

Puzicha M., Christus - Mitte der Benediktusregel, ErA 87 (2011) 18-35.

Ruppert F., Der Bruder als Reinigungsweg : Erfahrungen und Weisungen Benedikts, ErA 88 (2012) 306-307.

Standaert B., Saint Benoît et le Maître: à la recherche du rapport spirituel entre les deux, CCist 73 (2011) 321-334.

Stevenson K., Patristics and bishops. What four Fathers might say about episcopacy today, ,Theology” 114 (2011) 91-100.

Wolf N., Völlig abgefahren?: auf der Suche nach einem Profil benediktinischer Spiritualität im 21. Jahrhundert, „Ordensnachrichten” 50 (2011) nr 1, 27-34.

\section{Boecjusz}

Cerpa Estremadoyro R., Platonismo y creacionismo en la „Consolación de la filosofía” de Boecio, „Revista Teológica Limense” 2011, nr 2, 217-240.

Correia M., La similitud de los tratados silogísticos de Boecio y Apuleyo, TyV 52 (2011) 291-306.

Kiilerich B., Symmachus, Boethius and the Consecratio Ivory diptych, „Antiquité Tardive" 20 (2012) 205-215.

Laffleur Cl. - Carrier J., Alexandre d'Aphrodise et l'abstraction selon l'exposé sur les universaux chez Boèce dans son „Second commentaire sur l”Isagoge” de Porphyre, LThPh 68 (2012) 35-89.

Marenbon J., Boèce, Porphyre et les variétés de l'abstractionnisme, LThPh 68 (2012) 9-20.

Troncarelli F., Forbidden Memory: The Death of Boethius and the Conspiracy of Silence, „Mediaeval Studies” 73 (2011) 183-206.

Weiner S.F., Warum ist alles Seiende gut?. Boethius 'Argumentation in „,De hebdomadibus", FZPhTh 58 (2011) 271-289. 


\section{Braulio z Sarogossy}

Franco R.M., Posteridad literaria de las epístolas de Braulio de Zaragoza e Isidoro de Sevilla. Siglos VIII-XII, „Latomus” 71 (2012) 1102-1124.

Martín J.C., Tres textos hagiográphicos medievales sobre la ciudad de Zaragoza y sus Santos Valerio, Vicente y Braulio: edición y estudio, AnBol 130 (2012) 315-348.

\section{Brendan z Clonfert}

Iannello F., Il processo di cristianizzazione dell'aldilà celtico e delle divinità marine irlandesi nella „Navigatio sancti Brendani”, „Ilu” 16 (2011) 127-151.

Iannello F., Uso carácter y función de san Brendano de Clonfert en algunos textos irlandeses y continentales de la Edad Media, NV 35 (2011) 169-199.

\section{Celestiusz}

Egmond P.J., The Confessions of faith ascribed to Caelestius, SE 50 (2011) 317-339.

\section{Cezary z Arles}

Ferreiro A., The Catechetical Role of Children in the Sermons of Caesarius of Arles, VetCh 48 (2011) 243-260.

\section{Codex Theodosianus}

Wilkinson K.W., Dedicated widows in Codex Theodosianus 9.25?, JECS 20 (2012) 141-166.

\section{Collectio Hibernensis}

Gorman M.M., Patristic and pseudo-patristic citations in the ,, Collectio Hibernensis”, RBen 121 (2011) 18-93.

\section{Cyprian z Kartaginy}

Chronica Tertullianea et Cyprianea 2010., REAug 57 (2011) 375-427.

Ciccolini L., Un florilège biblique mis sous le nom de Cyprien de Carthage. L',Exhortatio de paenitentia” (CPL 65), RechAug 36 (2011) 89-138.

Gil-Tamayo J.A., ,, De unitate Patris et Filii et Spiritus Sancti” („, De oratione dominica 23)La unidad trinitaria como fundamento de la unidad eclesial en Tertuliano y Cipriano de Cartago, ScT 43 (2011) 9-29.

Gonzalez Salinero R., Apologetica antijudia y „Ecclesia potens” en Tertuliano y Cipriano, „Polis” 23 (2011) 35-59.

Livini A., Il caso della Cena Cypriani: riflessiono sulla circolazione alto-medievale di un libellus tardo-antico, „Wiener Studien” 124 (2011) 279-295.

Ramos-Lissón D., El culto a San Cipriano. Aproximación histórico-teológica a la eucología hispana, „Theologica” 47 (2012) 439-454.

\section{Cyprian z Kartaginy Pseudo-}

Burini De Lorenzi C., Pseudo Cipriano, „De duobus montibus” $e$ „Adversus Iudaeos ": il paradigma esegetico della polemica antigiudaica, „Auctores Nostri” 9 (2011) 187-198. 


\section{Cyryl Aleksandryjski}

Bertrand D., Das neunte Anathema. Der Heilige Geist in der Christologie Cyrills von Alexandrien, ZACh 15 (2011) 476-497.

Elliott M.W., What Cyril of Alexandria's „,De adoratione” is All About, StPatr 50 (2011) 245-252.

Van de Schoor R.J., Canisius als Herausgeber. Die Ausgaben von Tauler (1543), Kyrill (1546) und Leo dem Großen (1546), „Ons Geestelijk Erf” 82 (2011) 161-186.

Shchuryk O., The christological position of Cyril of Alexandria in his letter to Acacius of Melitene according to the Syriac version, ParOr 36 (2011) 381-412.

\section{Cyryl Jerozolimski}

Da Silva Mendonça Filho J., A re-significaçao do processo mistagógico de Sao Cirilo de Jerusalém, „Revista de cultura teológica” 19 (2011) nr 73, 89-100.

Ehret J., Les catéchèses mystagogiques de Cyrille de Jérusalem dans l'Office des Lectures mystagogie et Liturgie des Heures, CPE 2012, nr 126, 35-64.

Grignon S., Michée 5, 1 dans les ,, Catéchèses prébaptismales ” de Cyrille de Jérusalem: recension "lucianiste», "hexaplaire» ou «testimoniale»?, „Adamantius” 18 (2012) 297-306.

Maraval P., Les catéchèses mystagogiques de Cyrille de Jérusalem, CPE 2012, nr 126, 24-34

Vannier M.A., Cyrille de Jérusalem, CPE 2011, nr 124, 15-21.

\section{Cyryllonas}

Pasquet C., Cyrillonas, CPE 2011, nr 124, 47-52.

\section{Didache}

Draper J.A., The Two Ways and eschatological hope: a contested terrain in Galatians 5 and the „Didache”, „Neotestamentica” 45 (2011) 221-251.

Khomych T., Perfection in the „Didache”: Ethical Objective or Eschatological Hope?, StPatr 51 (2011) 3-13.

Larsen M.D., Addressing the elephant that's not in the room: comparing the Eucharistic prayers in ,Didache” 9-10 and the Last Supper tradition, „Neotestamentica” 45 (2011) 252-274.

Rosenfeld B.Z. - Levene A., „Didache” and Judaism-Jewish Roots of an Ancient Christian-Jewish Work, „Biblical Interpretation” 20 (2012) 172-175.

Stewart-Sykes A., „Didache » 14: Eucharistic?, „Questions Liturgiques » 93 (2012) 3-16.

Van de Sandt H., Why does the „Didache” conceive of the Eucharist as a holy meal?, VigCh 65 (2011) 1-20.

\section{Didascalia Apostolorum}

Bradshaw P.F., Women and Baptism in the „Didascalia Apostolorum”, JECS 20 (2012) 641-645.

\section{Dionizy Areopagita (Pseudo)}

Alfsvåg K., Luther as a reader of Dionysius the Areopagite, „Studia Theologica” 65 (2011) nr 2, 101-114. 
Andrés H.R., La participación: Meditación desde el aporte del Pseudo Dionisio, TyV 52 (2011) 253-268.

Fuentes J.J.U., Irracionalidad e hiperesencialidad en el Pseudo-Dionisio: Más allá de la razón y de la revelación, TyV 52 (2011) 269-278.

Ivanow E., Iconographic Interpretations of Theological Themes in Pseudo-Dionysius the Areopagite and in St. Gregory Palamas and the Reception of These Themes by Meister Eckhart, „Studi Teologice” 2011, nr 4, 161-176.

Ivanović F., The ecclesiology of Dionysius the Areopagite, „International |Journal for the Study of the Christian Church" 11 (2011) 27-44.

Lastra Sheridan J.C., Rectus ordo nominum: continuidad y divergencias en la relación de los nombres ,bien” y „ser” en „De divinis nominibus” del Pseudo-Dionisio Areopagita y el respectivo comentario de Alberto Magno, „Studium” 14 (2011) 131-143.

MacDonough C., Grounding speech and silence. Cataphaticism and apophaticism in Denys and Aquinas, ITQ 76 (2011) 57-76.

Podolak P., La composition du „Corpus Dionysiacum” et son authenticité supposée, „Apocrypha” 22 (2011) 167-181.

Sakvarelidze N., Hierarchie als Symphonie. Die Taxis des areopagitischen Kosmos, OrtF 25 (2011) 139-151.

Smith J.W., Divine ecstasy and divine simplicity. The eros motif in Pseudo-Dionysius's soteriology, „Pro Ecclesia” 21 (2012) 211-227.

Tavolaro G., Il contributo dello psudo-Dionigi alla teologia cristiana, „Asprenas” 58 (2011) 69-92.

Terezis Ch., Aspects of the theory of Dionysius the Areopagite concerning the divine processions as generating principles of the cosmos, „Augustinianum” 52 (2012) 441-457.

Vassányi M., Structure and meaning of St. Denys 'fundamental theology in „De divinis nominibus". A comparison with Proclus' theory of the one in Institutio theologica, „Bijdragen” 73 (2012) 404-415.

\section{Dionizy z Tel-Mahrē}

Wood Ph.J., The Chroniclers of Zuqnin and their times (c. 720-775), ParOr 36 (2011) 549-568.

\section{Dydym Aleksandryjski}

--, Commentary on Psalm 24 (23 LXX). Introduction, translation and commentary A.C. Geljon-Kees, VigCh 65 (2011) 50-73.

Muscolino G., L'allegoria di Didimo contro l'ironia di Porfirio sull'onnipotenza di Dio: analisi del ,C Commentario a Giobbe” 10, 13 (P. Tura 280, 1-281, 13), „Auctores Nostri” 9 (2011) 317-332.

Radde-Gallwitz A., The Holy Spirit as agent, not activity: Origen's argument with modalism and its afterlife in Didymus, Eunomius, and Gregory of Nazianzus, VigCh 65 (2011) 227-248.

\section{Egeria}

Vannier M.A., Égérie, pèlerinage en Terre Sainte, CPE 2011, nr 124, 13-14. 


\section{Efrem Syryjczyk}

Baarda T., Mk 1:41: orgistheis. A reading attested for Mar Ephraem, the Diatessaron, or Tatian, ZNW 103 (2012) 291-295.

Cheriampanatt J., Eucharistic hermeneutics of the Church in St. Ephrem, „Ephrem's Theological Journal" 15 (2011) nr 1, 49-54.

Daelemans B., Dieu sauve en se montrant. La révélation rédemptrice dans la troisième „Hymne sur la nativité” de St. Éphrem, OCP 77 (2011) 351-398.

Daelemans B., Le Caché nous relève en se révélant. La révélation rédemptrice dans les „Hymnes sur la Nativité,, de St. Éphrem, OCP 78 (2012) 29-80.

Hunt H.M., ,, Working the Earth of the Heart": Images of Cultivation and Harvest in Macarius and Ephrem, StPatr 52 (2011) 149-160.

Thattaparambil M., St Ephrem's „Hymns on Epiphany”. A door to the Christian initiation, „Malabar Theological Review” 6 (2011) 59-72.

Vattanky J., Ephrem and Śamkara: a dialogue between two creative thinkers, ParOr 36 (2011) 525-532.

Vergani E., L'exégèse de Éz 37 chez Éphrem le Syrien, ParOr 36 (2011) 533-548.

\section{Epifaniusz z Salaminy}

Jacobs A.S., Matters (Un-)Becoming: Conversions in Epiphanius of Salamis, ChH 81 (2012) 27-47.

Schmid H., Ist der Soter in Ptolemäus ', Epistula ad Floram” der Demiurg?: zu einer These von Christoph Markschies, ZACh 16 (2012) 249-271.

Scott Manor T., Epiphanius' Account of the Alogi: Historical Fact or Heretical Fiction?, StPatr 52 (2011) 161-170.

Solovieva O., Epiphanius of Salamis between Church and state: new perspectives on the iconoclastic fragments, ZACh 16 (2012) 344-367.

\section{Eucheriusz z Lyonu}

Kelly Ch., The myth of the desert in Western monasticism. Eucherius of Lyon's „In praise of the desert”, „Cistercian Studies Quarterly” 46 (2011) 129-141.

\section{Eunomiusz}

Radde-Gallwitz A., The Holy Spirit as agent, not activity. Origen's argument with modalism and its afterlife in Didymus, Eunomius, and Gregory of Nazianzus, VigCh 65 (2011) 227-248.

Wallraff M., Heterodoxie und Kirchengeschichte. Der Eunomianismus des Philostorgios und der Novatianismus des Sokrates, OrtF 25 (2011) / 201-211.

\section{Eustacjusz z Antiochii}

Cartwright S.H., The Human Soul between Death and Resurrection in Eustathius of Antioch, StPatr 52 (2011) 139-147.

De Navascués Benlloch P., ,C Cuerpo” en la tradición antioquena: el caso de Eustacio de Antioquía, „Augustinianum” 51 (2011) 21-45.

\section{Euzebiusz z Cezarei}

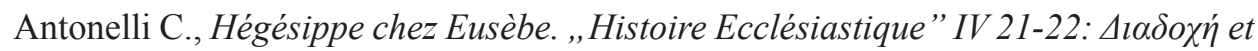
origine des hérésies, „Apocrypha” 22 (2011) 185-232. 
Carrier R.C., Origen, Eusebius, and the accidental interpolation in Josephus: Jewish Antiquities 20.200, JECS 20 (2012) 489-514.

Ceulemans R., On a Commentary Attributed to Eusebius of Caesarea and Nilus (the Monk / the Anchorite), „Adamantius” 18 (2012) 283-296.

Horn C.B., Methodological and thematic perspectives on children and childhood in the first half of Eusebius of Caesarea's „,Church history”, „Rivista di Storia del Cristianesimo" 8 (2011) 231-259.

Hubenak F., La construccion del mito de Constantino a partir de Eusebio de Cesarea, „Polis” 23 (2011) 61-87.

Johnson A.P., The tenth book of Eusebius' ,, General elementary introduction ”. A critique of the Wallace-Hadrill thesis, JTS 62 (2011) 144-160.

Litfin B.M, Eusebius on Constantine: truth and hagiography at the Milvian Bridge, „Journal of the Evangelical Theological Society” 55 (2012) 773-792.

Martin A., D’Eusèbe à Sozomène: la place du monachisme dans les nouvelles „Histoires ecclésiastiques”, „Adamantius” 17 (2011) 93-117.

Morlet S., La formation d'une identité intellectuelle et son cadre scolaire: Eusèbe de Césarée à l'«école» de Pamphile, „Adamantius” 17 (2011) 208-219.

Simonetti M., Eusebio eresiografo: un libro recente, „Adamantius” 17 (2011) 338347.

Toda S., Eusebius and Syriac literature, ParOr 36 (2011) 515-524.

\section{Euzebiusz z Vercelli}

Simonetti M., Ancora una nota su Eusebio di Vercelli, „Augustinianum” 52 (2012) 347-351.

\section{Ewagriusz Scholastyk}

Giorda M.C., Monaci e monachesimi nella ,Storia ecclesiastica” di Evagrio Scolastico, „Adamantius” 17 (2011) 118-132.

\section{Ewagriusz z Pontu}

Azzone P., Sin of sadness: ,, acedia vel tristitia” between sociocultural conditionings and psychological dynamics of negative emotions, „Journal of Psychology and Christianity" 31 (2012) 16-30.

Bitton-Ashkelony B., The limit of the mind (nus) : pure prayer according to Evagrius Ponticus and Isaac of Nineveh, ZACh 15 (2011) 291-321.

Bradford D.T., Evagrius Ponticus and the psychology of „, natural contemplation”, „Studies in Spirituality” 22 (2012) 109-125.

Casiday A.M., On heresy in modern patristic scholarship: the case of Evagrius Ponticus, The Heythrop Journal" 53 (2012) 241-252.

Kalvesmaki J., The „Epistula fidei ”of Evagrius of Pontus: an answer to Constantinople, JECS 20 (2012) 113-139.

Peretó Rivas R.A., Evagrio Póntico y la exclaustración de la acedia , „Carthaginensia” 28 (2012) 23-35.

Scully J., Angelic pneumatology in the Egyptian desert. The role of the angels and the Holy Spirit in Evagrian asceticism, JECS 19 (2011) 287-305.

Smither E.L., Lessons from a tentmaking ascetic in the Egyptian desert: the case of Evagrius of Pontus, „Missiology” 39 (2011) 485-496. 
Stewart C., Evagrius Ponticus and the Eastern monastic tradition on the intellect and the passions, „Modern theology” 27 (2011) 263-275.

\section{Filon z Aleksandrii}

Alesse F., La „radice della mente” in Phil. Alex. „Quod deter.” 84-85. Breve analisi di una metafora astrologica, „MHNH” 11 (2011) 218-228.

De los Santos Granados L., Aportaciones filosóficas de Filón, san Teófilo y san Ireneo al concepto de pecado original, „Anuario de Historia de la Iglesia” 21 (2012) 511-519.

Lincicum D., Philo on Phinehas and the Levites. Observing an exegetical connection, „Bulletin for Biblical Research” 21 (2011) 43-50.

Nauroy G., La création de l'homme $(G n$ 1, 26) dans une lecture critique de Philon le Juif: la lettre 29 (43M) d'Ambroise de Milan face au „,De opificio mundi”, CPE 2012, nr 125, 39-49.

Reddoch M.J., Philo of Alexandria's Use of Sleep and Dreaming as Epistemological Metaphors in Relation to Joseph, „The International Journal of the Platonic Tradition" 5 (2011) 283-302.

Roure D., Forgiveness in Ben Sira and in Philo of Alexandria, SMon 53 (2011) 7-19.

Weisser S., Why Does Philo Criticize the Stoic Ideal of Apatheia in on Abraham 257? Philo and Consolatory Literature, CQ 62 (2012) 242-259.

\section{Filostorgiusz}

Wallraff M., Heterodoxie und Kirchengeschichte. Der Eunomianismus des Philostorgios und der Novatianismus des Sokrates, OrtF 25 (2011) / 201-211.

\section{Firmicus Maternus}

Annecchino M., La polemica nel „,De errore profanarum religionum” di Firmico Materno, „Auctores Nostri” 9 (2011) 341-358.

Weaver B., Synthesis of Cultic and Mythic traditions in Firmicus Maternus 'Stoicizing Dionysiac Aetiology (De err. 6.5), „Mythos” 5 (2011) 149-171.

\section{Focjusz}

Alexopoulos Th., Konstantinos Melitiniotes and Photios of Constantinople on the Filioque. A Comparative Study, StPatr 50 (2011) 289-300.

Hainthaler Th., Die Enzyklika des Photios an die Patriarchen des Ostens: eine Vorlage für antilateinische Polemik, ,Ostkirchliche Studien” 60 (2011) 266-279.

\section{Gelazy I papież}

Ronzani R., La lettera „famuli vestrae pietatis” di Gelasio di Roma all'imperatore Anastasio I (CPL 1667, Ep. 8), „Augustinianum” 51 (2011) 501-549.

Bouhot J.P., Trois rituels occasionnels du baptème dans le sacramentaire gélasien, RBen 122 (2012) 125-152.

\section{German z Auxerre}

Aprile B., Davide figura di Cristo in alcuni testi delle Enarrationes in psalmos di Agostino d'Ippona, „Miscellanea Franciscana” 112 (2012) 347-363. 
Bottiglieri C., L'epitome della vita di S. Germano di Auxerre nel ms. Paris, BNF lat. 12598, „Hagiographica” 18 (2011) 89-134.

\section{Grzegorz Cudotwórca}

--, Trattato circa la non passibilità o passibilità di Dio, testo siriaco e traduzione italiana M. Pazzini, „Liber Annuus” 61 (2011) 377-411.

\section{Grzegorz Oświeciciel}

Beylot R., Trois notes: sur le bois de la Croix, sur Grégoire l'Illuminateur au Concile de Nicée dans la Gloire des Rois et sur une source arabe du Livre des Mystères du Ciel et de la Terre, „Aethiopica”14 (2011) 210-214.

\section{Grzegorz Oświeciciel Pseudo-}

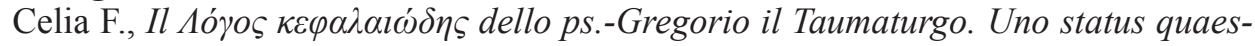
tionis e un primo approccio al problema delle fonti, ,Adamantius” 17 (2011) 164-189.

\section{Grzegorz Palamas}

Dumitrascu N., L'intelletto umano immobile dinanzi alla luce divina. Dumitru Staniloae interprete di Gregorio Palamàs, SMon 53 (2011) 329-336.

Ivanow E., Iconographic Interpretations of Theological Themes in Pseudo-Dionysius the Areopagite and in St. Gregory Palamas and the Reception of These Themes by Meister Eckhart, ,Studi Teologice” 2011, nr 4, 161-176.

\section{Grzegorz Wielki}

Cracco G., Tra gerarchie di Dio e gerarchie della storia: le avventure di un testochiave di Gregorio Magno, RSLR 47 (2011) 3-30.

DelCogliano M., Gregory the Great on Simon of Cyrene: a critique of tradition, ASE 28 (2011) 315-324.

Elders L.J., La présence de saint Grégoire le Grand dans les oeuvres de saint Thomas d'Aquin, NV 86 (2011) 155-180.

González Vidal N., Gregorio Magno y la psicología, TyV 52 (2011) 279-290.

Hillner J., Gregory the Great's ,,Prisons”: monastic confinement in early Byzantine Italy, JECS 19 (2011) 433-471.

Laham Cohen R., En torno a motivaciones y efectos del discurso antijudio: el caso de los ,Moralia in Iob” de Gregorio Magno, „Polis” 23 (2011) 115-151.

Puzicha M., Das zweite Buch der „Dialoge” Gregors d. Gr.: Leitlinien des neuen Kommentars, ErA 88 (2012) 296-305.

Stevenson K., Patristics and bishops. What four Fathers might say about episcopacy today, ,Theology” 114 (2011) 91-100.

Trisoglio F., La catechesi ai vescovi: la „Regula pastoralis” di san Gregorio Magno, „Rivista Lasalliana” 78 (2011) 607-620.

\section{Grzegorz z Elwiry}

Shuve K., Origen and the „Tractatus de Epithalamio” of Gregory of Elvira, StPatr 50 (2011) 189-203. 


\section{Grzegorz z Nazjanzu}

Bayliss G.D., The „Measured” Approach: Bad Pun or Theological Stance in the Poetry of Gregory of Nazianzus?, StPatr 52 (2011) 171-183.

Bucur B.G. - Mueller E.N., Gregory Nazianzen's reading of Habbakuk 3:2 and its reception. A lesson of Byzantine Scripture exegesis, „Pro Ecclesia” 20 (2011) 86-103.

Fulford B., Divine Names and the Embodied Intellect: Imagination and Sanctification in Gregory of Nazianzus' Account of Theological Language, StPatr 50 (2011) 217-231.

Kaplan A., Les copistes du manuscrit syriaque BL Add. 12153 (Homélies de Grégoire de Nazianze), OCP 77 (2011) 327-349.

Maslov B., Oikeiosis pros theon. Gregory of Nazianzus and the heteronomous subject of Eastern Christian penance, ZACh 16 (2012) 311-343.

Matz B., Baptism as theological intersection in Gregory Nazianzen's „Oration” 39, SE 51 (2012) 35-58.

Merino Rodríguez M., El diálogo de Dios y con Dios en San Gregorio de Nacianzo, „Estudios Trinitarios” 46 (2012) 3-61.

Norris F.W., Gregory Nazianzus' Poemata Arcana: A Poetic, Musical Catechism?, „Union Seminary Quarterly Review” 63 (2012) nr 3-4, 62-75.

Pasquet C., Grégoire de Nazianze, CPE 2011, nr 124, 26-32.

Radde-Gallwitz A., The Holy Spirit as agent, not activity. Origen's argument with modalism and its afterlife in Didymus, Eunomius, and Gregory of Nazianzus, VigCh 65 (2011) 227-248.

Storin B.K., In a silent way. Asceticism and literature in the rehabilitation of Gregory of Nazianzus, JECS 19 (2011) 225-257.

Trisoglio F., Evangelizzazione ed educazione in S. Gregorio di Nazianzo, „Rivista Lasalliana" 78 (2012) 307-314.

Villagómez F., El sacerdocio en la „Oratio” II de Gregorio Nacianceno, „Ecclesia” 2012, nr 1, 49-60; nr 2, 175-202.

Zagórski D., The Model of the Perfect Christian in the Writings of Gregory of Nazianzus, StPatr 51 (2011) 63-75.

\section{Grzegorz z Nyssy}

Baghos M., The meaning of history. Insights from St Gregory the theologian's existential metanarrative, „Colloquium” 43 (2011) 17-38.

Boersma H., Overcoming Time and Space: Gregory of Nyssa's Anagogical Theology, JECS 20 (2012) 575-612.

Boersma H., „, This is the day, which the Lord has made”: scripture, manumission, and the heavenly future in Saint Gregory of Nyssa, „Modern Theology” 28 (2012) 657-672.

Brugarolas M., La procesión del Espíritu Santo en Gregorio de Nisa, ScT 44 (2012) 45-70.

Capboscq A.C., El uso de la imagen de la fuente en el In canticum canticorum de Gregorio de Nisa, ,Erytheia” 32 (2011) 95-138.

Conway-Jones A., The Garments of Heaven: Gregory of Nyssa's Interpretation of the Priestly Robe (,,Life of Moses” 2, 189-191) Seen in the Light of Heavenly Ascent Texts, StPatr 50 (2011) 207-215.

Curzel Ch., Gli ossimori nelle omelie sul Cantico dei cantici e nella „Vita di Mosè” 
di Gregorio di Nissa, „Augustinianum” 51 (2011) 47-83

Ide P., La trilogie patristique de Balthasar (Origène, Grégoire de Nysse et Maxime). Une première ébauche de sa Théologie de l'amour, „Gregorianum” 93 (2012) 711-744.

Izquierdo Urbina C., La simbología eclesial en las „Homilías sobre el Cantar de los Cantares”, de Gregorio de Nisa, „Anales de Teologia” 14 (2012) 99-114.

Maspero G., Unità e relazione: la schesis nella dottrina trinitaria di Gregorio di Nissa, „PATH” 11 (2012) 301-326.

Orton R., Reassembly, Purification or Restoration: The Resurrection of the Body in St Gregory of Nyssa, StPatr 52 (2011) 185-195.

Pardue S., On faithfully knowing an infinite God. Humility as an intellectual virtue in Gregory of Nyssa's „, Contra Eunomium” II, „International Journal of Systematic Theology" 13 (2011) 62-76.

Petcu L., Sfântul Grigorie al Nyssei despre infinitatea divină, „Classica \& Christiana” 7 (2012) 537-562.

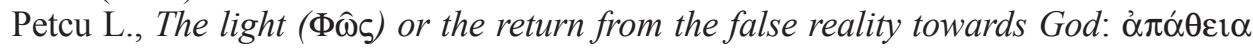
and $\pi \alpha \rho p \eta \sigma i \alpha$ in St. Gregory of Nyssa, „Classica \& Christiana” 7 (2012) 221-234.

Radde-Gallwitz A., Gregory of Nyssa's pneumatology in context. The Spirit as anointing and the history of the Trinitarian controversies, JECS 19 (2011) 259-285.

Reyes E., „La voz del Amado”. Palabras de promesa y realidad del entendimiento en el „Com. Cant.” de Gregorio de Nisa, TyV 52 (2011) 181-196.

Somenzi C., Le Beatitudini come itinerario di preparazione al battesimo: lo sfondo esegetico-liturgico delle Omelie sulle Beatitudini di Gregorio di Nissa, „Adamantius” 17 (2011) 238-256.

Sperlea O., Syméon le Nouveau Théologien comme témoin de la tradition spirituelle de Grégoire de Nysse, SMon 54 (2012) 235-252.

Trisoglio F., La catechesi al clero in S. Gregorio di Nissa, „Rivista Lasalliana” 78 (2011) 195-210.

Vannier M.A., Grégoire de Nysse, CPE 2011, nr 124, 33-35.

\section{Grzegorz z Tours}

Aguirre Durán M.E., Hagiografía, milagros y providencia: fundamentos teológicohistóricos de la Historia Francorum de Gregorio de Tours (siglo VI),

Boesch Gajano S., Gregorio di Tours: scrittura della storia e storie di monaci, „Adamantius” 17 (2011) 81-92.

De Mico N., La lucida follia di Fredegunde, regina specchio del suo tempo (dalle „Historiae” di Gregorio di Tours), ,Rivista di Cultura Classica e Medievale” 54 (2012) 133-164.

Ferreiro A., Discourse sermons in the „Libri historiarum decem” of Gregory of Tours, „Revue d'histoire ecclésiastique” 107 (2012) 49-77.

Richardot Ph., Grégoire de Tours et Isidore de Séville historiens militaires, „Latomus” 71 (2012) 150-160.

\section{Hegezyp}

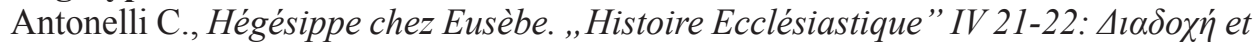
origine des hérésies, „Apocrypha” 22 (2011) 185-232. 


\section{Hermas}

Henne Ph., Le tout premier catéchisme chrétien: le „Pasteur” d'Hermas, MSR 69 (2012) nr 2, 5-15.

Batovici D., Contrasting ecclesial functions in the second century: ,diakonia”, „diakonoi”, ,, episkopoi” and „presbyteroi” in the „Shepherd” of Hermas and Ignatius of Antioch's ,Letters”, „Augustinianum” 51 (2011) 303-314.

\section{Hieronim}

Alciati R., ,, Sine aliqua differentia graduum” (Hieronymus, „Adversus Iovinianum” 2, 19): ascetismo e matrimonio nella predicazione di Gioviniano, „Rivista di Storia del Cristianesimo" 8 (2011) 305-328.

Canton S., Cultura classica e ascetismo cristiano in san Gerolamo: incontro o scontro?, „Sileno” 38 (2012) 89-107.

De Luis Vizcaíno P., Presencia de la carta 22 de san Jerónimo en el Praeceptum de san Agustín, EstA 46 (2011) 203-231.

Degórski B., Dittico simbolico di ,silencio” e ,parola” nelle Vitae geronimiane di Paolo e Ilarione, Angelicum" 89 (2012) 49-64.

Dunn G.D., The call to perfection, financial asceticism, and Jerome, „Augustinianum” 52 (2012) 197-218.

Gallagher E.L., The Old Testament ,, apocrypha” in Jerome's canonical theory, JECS 20 (2012) 213-233.

Grandi G., Quo ille valde delectatus, quod scilicet antagonistas haberet in proximo. La costruzione polemica di personaggi ed episodi nelle opere biografiche di Gerolamo, „Auctores Nostri” 9 (2011) 621-638.

Harritsø L., Kainfortaellingen $i$ antikke oversaettelser og fortolkninger, „Dansk Teologisk Tidsskrift" 75 (2012) 187-202.

Hasselhoff G.K., Revising the Vulgate: Jerome and his Jewish interlocutors, ZRGG 64 (2012) 209-221.

Hunt T., Biblical interpretation in Jerome of Stridon's „, Vita Hilarionis”, StPatr 52 (2011) 247-255.

Jacobitz G., The epistolary correspondence of Saints Jerome and Augustine and the expansion of the ,Rule” of Saint Benedict from 66 to 73 chapters, ABR 63 (2012) 384-418.

Lumma L.O., ,,... ut cunctis mundo purget erroribus”: das Begriffspaar „, Reinheit - Irrtum" in den Orationes sollemnes der Karfreitagsliturgie, ZKT 134 (2012) 471-480.

M ${ }^{\mathrm{a}}$ Trinitat Cabrero, Rasgos característicos de la Espiritualidad Jerónima, „Liturgia y Espiritualidad" 42 (2011) 319-323.

Milazzo V., Una confutazione per immagini. Notazioni sul ritratto dell'avversario nelle opere polemiche di Gerolamo, „Auctores Nostri” 9 (2011) 387-409.

Monaci Castagno A., „Primus in primis”: Gerolamo, storico del monachesimo, „Adamantius” 17 (2011) 10-22.

Mülke M., Hieronymus und Johannes Chrysostomos: (zu Hier. „In Tit.” 1, 12 und „Epist.” 70, 2), VigCh 66 (2012) 93-102.

Nugent P., Patrística y pedagogía: Jerónimo y Agustín, „Augustinus” 56 (2011) 159-164.

Skemp V.T., Learning by example. ,exempla” in Jerome's translations and revisions of biblical books, VigCh 65 (2011) 257-284. 
Tampellini S., Le „, Omelie su Luca” da Origene a Gerolamo (e Ambrogio): considerazioni introduttive, „Adamantius” 18 (2012) 226-232.

Zugravu N., Moderata saturitas la Hieronymus, „Classica \& Christiana” 7 (2012) 597-616.

\section{Hilary z Poitiers}

Cantó J.M.S., Originalidad teológica del „Liber de Synodis seu de Fide Orientalium et Apologetica Responsa” de Hilario de Poitiers, „Escritos del Vedat” 41 (2011) 93-158.

Scully E., The soteriology of Hilary of Poitiers: a Latin mystical model of redemption, „Augustinianum” 52 (2012) 159-195.

Scully E., Jerusalem: image of Hilary's Christocentric eschatology in the „, Tractatus super Psalmos", VigCh 66 (2012) 269-282.

Sotomayor Larraín C., Sobre la propuesta de Hilario en el „De Synodis”, TyV 52 (2011) 167-180.

\section{Hipolit}

Cirafesi W.V. - Peterman G.W., Pistis and Christ in Hippolytus's „De Christo et Antichristo": a response to Michael F. Bird and Michael R. Whitenton, NTS 57 (2011) 594-603.

Douglas B., A ,great thanksgiving” modelled on „, The Apostolic Tradition”: a case for reception of Eucharist multiformity in the Anglican Church of Australia, „Questions Liturgiques" 92 (2011) 112-129.

Marcus J., Israel and the Church in the Exegetical Writings of Hippolytus, JBL 131 (2012) 385-406.

Moreschini C., Motivi ed intenti dell',Elenchos” di Ippolito, „Auctores Nostri” 9 (2011) 215-232.

\section{Hipolit Pseudo-}

Genovese A., L'agnello pasquale nella „Homilia in Sanctum Pascha” dello Pseudo Ippolito. Una breve nota soteriologica, „Euntes Docete” 64 (2011) 207-217.

\section{Ignacy z Antiochii}

Batovici D., Contrasting ecclesial functions in the second century: ,diakonia”, „,diakonoi", ,, episkopoi" and „presbyteroi" in the „Shepherd" of Hermas and Ignatius of Antioch's „,Letters”, „Augustinianum” 51 (2011) 303-314.

Harmon S.R., Qualitative catholicity in the Ignatian correspondence - and the New Testament. The fallacies of a restorationist hermeneutic, „Perspectives in Religious Studies" 38 (2011) 33-45.

Schmidt Andrade C., San Ignacio de Antioquía y el camino hacia la Cruz, „Anámnesis” 22 (2012) $\mathrm{nr} 44,27-54$.

Trisoglio F., S. Ignazio d'Antiochia, araldo dell'unità, ,Rivista Lasalliana” 78 (2012) 161-170.

\section{Innocenty I}

Dunn G.D., Innocent I's appointment of Boniface as papal legate to Constantinople?, SE 51 (2012) 135-150. 
Dunn G.D., The development of Rome as metropolitan of suburbicarian Italy: Innocenti's „Letter to the Bruttians”, „Augustinianum” 51 (2011) 161-190.

\section{Ireneusz z Lyonu}

Albornoz Olivares L.M., La salvación como visión de Dios: aproximación en clave profética al concepto de salvación en San Ireneo de Lyon, „Veritas” 2011, nr 24, 165-185.

Briggman A., Revisiting Irenaeus'philosophical acumen, VigCh 65 (2011) 115-124.

Briggman A., Spirit-Christology in Irenaeus: a closer look, VigCh 66 (2012) 1-19.

Chamorro G.M., Ireneo de Lyon: Vida, obra y relevancia para la historia, „Cuadernos de Teología" 31 (2012) 54-74.

Cornelius E., St. Irenaeus and Robert W. Jenson on Jesus in the Trinity, „Journal of the Evangelical Theological Society" 55 (2012) 111-124.

Cuadros J.D.R., Frente a herejías y sociedades en decadencia: análisis comparativo de los modelos eclesiales en Ireneo de Lyon y Agustín de Hipona, „Reflexiones Teológicas" 7 (2011) 123-154.

De los Santos Granados L., Aportaciones filosóficas de Filón, san Teófilo y san Ireneo al concepto de pecado original, „Anuario de Historia de la Iglesia” 21 (2012) 511-519.

Giraud G., Pour une théologie ,apocalyptique” de l'histoire. Une lecture de l',Adversus haereses” V,III, RSR 99 (2011) 415-435.

Lashier J., Irenaeus as Logos theologian, VigCh 66 (2012) 341-361.

Merkt A., „Amt der Tradition” und „Charisma der Wahrheit”. Die theologische Bedeutung der apostolischen Sukzession bei Irenäus von Lyon und Augustinus, „Internationale katholische Zeitschrift „Communio” 40 (2011) 221-233.

Presley S.O., The Lost Sheep who is Found: Irenaeus'Intertextual Reading of Genesis 3 in „Adversus haereses” III 23.1-8, StPatr 52 (2011) 47-59.

Schmidt M., Kirchenspaltungen als Möglichkeit zur Reifung. Die Wachstumstheorie bei Irenäus von Lyon im ökumenischen Kontext, „Zeitschrift für katholische Theologie" 134 (2012) 55-62.

Smit P.B., The reception of the truth at baptism and the church as epistemological principle in the work of Irenaeus of Lyons, „Ecclesiology” 7 (2011) 354-373.

Steenberg M.C., The „Gospel of Truth” and the Truth of the Gospel: Assessing the Scope of Valentinian Influence on the Thought of St Irenaeus, StPatr 50 (2011) 89-103.

Van der Sypt L., The unreliability of Irenaeus's reference to syneisaktism („Adversus haereses" I 6,3), VigCh 66 (2012) 551-557.

White B.L., How to read a book. Irenaeus and the Pastoral Epistles reconsidered, VigCh 65 (2011) 125-149.

\section{Izaak z Niniwy}

Bitton-Ashkelony B., The limit of the mind (nus) : pure prayer according to Evagrius Ponticus and Isaac of Nineveh, ZACh 15 (2011) 291-321.

\section{Izydor z Peluzjum}

Lucchesi E., Un fragment bohaïrique du martyre d'Isidore et Sané, AnBol 129 (2011) 5-10. 
Cambe M., Isidore de Péluse interprète de Jacques 3, 6: "Le cosmos de l'injustice», «la roue de l'existence», RHPR 92 (2012) 387-411.

\section{Izydor z Sewilli}

Carpin A., La temperanza in Isidoro di Siviglia. Dalla patristica alla scolastica, SC 57 (2012) 237-356.

Crivat A., El léxico de lo extraordinario en las „Etimologías” de Isidoro de Sevilla (portenta, ostenta, prodigia, monstra), „Revue Roumaine de Linguistique” 56 (2011) 257-276.

Elfassi J., À la recherche du commentaire littéral sur la Genèse d'Isidore de Séville, CPE 2012, nr 125, 50-60.

Ferraces Rodriguez A., Latín vulgar $(b>m)$ y etimología: el zoónimo uerbex según Isidoro de Sevilla (Etym. 12, 1, 10), „Helmantica” 63 (2012) 73-86.

Franco R.M., Posteridad literaria de las epístolas de Braulio de Zaragoza e Isidoro de Sevilla. Siglos VIII-XII, „Latomus” 71 (2012) 1102-1124.

Menegaldo S., Géographie et imaginaire insulaire au Moyen Âge, d'Isidore de Séville à Jean de Mandeville. L'île le dans la littérature, „Lettres Romanes” 66 (2012) 37-86.

Rzepkowski K., Isidore of Seville and „,comici veteres”. Ad Isid, Orig. VIII 7.7, „Emérita” 80 (2012) 341-353.

Salvador-Bello M., Clean and unclean Animals: Isidore's Book XII from the ,Etymologiae” and the structure of Eusebius's zoological Riddles, „English Studies" (online) 93 (2012) 572-582.

Schick C., Isidor von Sevilla und die Astronomie, „Theologisches” 41 (2011) nr 2, 107-110.

Trisoglio F., La catechesi liturgica: il „,De ecclesiasticis officiis” di Isidoro di Siviglia, „Rivista Lasalliana” 78 (2011) 395-410.

Van der Horst P.W., Isidorus van Sevilla over God: „Etymologiae” 7.1: vertaald en toegelicht, NThT 66 (2012) 61-70.

\section{Jan Chryzostom}

Antonescu C., Putere politică şi putere bisericească la Sfântul Ioan Gură de Aur, „Studi Teologice” 2011, nr 1, 111-144.

Cloşcă T., Metafora corabiei în opera lui Ioan Hrisostom, „Classica \& Christiana” 6 (2011) 387-406.

Delgado J.I., La traduction des Pères grecs aujourd'hui. Le cas de saint Jean Chrysostome. Méthodologie pour l'édition des sources manuscrites et imprimées, „Helmantica” 63 (2012) 401-417.

DeWet Ch.L., John Chrysostom's exegesis on the resurrection in 1 Corinthians 15, «Neotestamentica» 45 (2011) 92-114.

Gorman M.M., Annianus of Ceneda and the Latin Translations of John Chrysostom's „Homilies on the Gospel of Matthew”, RBen 122 (2012) 100-124.

Hall T.N. - Norris M., The Chrysostom texts in Bodley 516, JTS 62 (2011) 161-175.

Hofer A., The reordering of relationships in John Chrysostom's „De sacerdotio”, „Augustinianum” 51 (2011) 451-471.

Kanaan M., Le diable et les démons chez saint Jean Chrysostome, BLE 113 (2012) 291-302. 
Karmann Th.R., Johannes Chrysostomus und der Neunizänismus: eine Spurensuche in ausgewählten Predigten des antiochischen Presbyters, SE 51 (2012) 79-108.

Lucchesi E., Deux témoins coptes de 1'homélie sur 1'archange Gabriel, attribuée à Jean Chrysostome, AnBol 129 (2011) 324.

Moore P., Plain talk with a gilt edge. An exploration of the relation between ,plain” biblical exposition and persuasion in Chrysostom and Calvin, „Westminster Theological Journal" 73 (2011) 157-172.

Morlet S., La source principale du „Quod Christus sit Deus” attribué à Jean Chrysostome: la „Démonstration évangélique” d'Eusèbe de Césarée, REAug 58 (2012) 261-285.

Mülke M., Hieronymus und Johannes Chrysostomos: (zu Hier. „In Tit.” 1, 12 und „Epist.” 70, 2), VigCh 66 (2012) 93-102.

Müller-Abels S., Christliche Gemeinde in einer spätantiken Großstadt: die Apostelgeschichtshomilien des Johannes Chrysostomus, SE 51 (2012) 109-134.

Rotondo A., Aípe $\sigma ı \varsigma$ e $\sigma \chi i \sigma \mu \alpha$ in 1Cor: la lettura di Giovanni Crisostomo, „Auctores Nostri" 9 (2011) 143-159.

Sandwell I., How to teach Genesis 1.1-19: John Chrysostom and Basil of Caesarea on the creation of the world, JECS 19 (2011) 539-564.

Sautel J.H., Le choix du type de réglure dans les manuscrits byzantins: les „,Homélies sur la Genèse" de saint Jean Chrysostome conservées à la BNF (Paris, BNFf, gr. 602-652), „Scriptorium” 66 (2012) 221-280.

Stevenson K., Patristics and bishops. What four Fathers might say about episcopacy today, ,Theology” 114 (2011) 91-100.

Trisoglio F., La catechesi battesimale a doppia intonazione: Giovanni Crisostomo, „Rivista Lasalliana” 78 (2011) 7-18.

Trisoglio F., La spiritualità dei secolari nei tre libri di S. Giovanni Crisostomo in difesa del monachesimo, „Rivista Lasalliana” 79 (2012) 461-472.

Trisoglio F., San Giovanni Crisostomo: l'educatore di una popolazione smarrita e spaventata, „Rivista Lasalliana” 79 (2012) 17-30.

Vannier M.A., Jean Chrysostome, CPE 2011, nr 124, 22-25.

Zincone S, Modelli della polemica antigiudaica di Giovanni Crisostomo con particolare riferimento alle omelie „Adversus Iudaeos”, „Auctores Nostri” 9 (2011) 199-214.

\section{Jan Damasceński}

Blowers P.M., Maximus the Confessor and John of Damascus on Gnomic Will ( $\gamma v \omega ́ \mu \eta)$ in Christ: Clarity and Ambiguity, „Union Seminary Quarterly Review” 63 (2012) nr 3-4, 44-50.

Erismann Ch., A World of Hypostases: John of Damascus' Rethinking of Aristotle's Categorical Ontology, StPatr 50 (2011) 269-287.

Rhodes M.C., Handmade: a Critical Analysis of John of Damascus's Reasoning for Making Icons, „The Heytrop Journal” 52 (2011) 14-26.

Zhyrkova A., John Damascene's Conception of Individual: Hypostasis versus Person, StPatr 52 (2011) 375-387.

\section{Jan Filoponos}

Glede B., Johannes Philoponos und die christliche Apologetik. Die Widerlegungen 
des Proklos und Aristoteles und die Debatte des Schöpfungsproblems in der

Schule von Gaza und bei Ps-Justin, JACh 54 (2011) 73-97.

\section{Jan Kasjan}

Alciati R., Verus Israhel, id est monachorum plebs: la genealogia monastica di Cassiano, „Adamantius” 17 (2011) 67-80.

Krawiec R., Monastic Literacy in John Cassian: Toward a New Sublimity, ChH 81 (2012) 765-795.

Mongrain K., Theologians of spiritual transformation: a proposal for reading René Girard through the lenses of Hans Urs von Balthasar and John Cassian, „Modern Theology" 28 (2012) 81-111.

Robertson D., „Lectio divina” and literary criticism: from John Cassian to Stanley Fish, „Cistercian Studies Quarterly” 46 (2011) 83-93.

Vannier M.A., Le voyage de Jean Cassien en Palestine, CPE 2011, nr 122, 51-60.

\section{Jan z Apamei}

Bitton-Ashkelony B., ,, More Interior than the Lips and the Tongue”: John of Apamea and Silent Prayer in Late Antiquity, JECS 20 (2012) 303-331.

\section{Jerzy z Laodycei}

DelCogliano M., George of Laodicea. A historical reassessment, JEH 62 (2011) 667692.

DelCogliano M., The literary corpus of George of Laodicea, VigCh 65 (2011) 150-169.

\section{Jan z Nikiu}

Booth Ph., Shades of Blues and Greens in the Chronicle of John of Nikiu, ByzZ 104 (2011) 555-601.

\section{Jerzy Synkellos}

Arcari L., "Are women the aition for the Evil in the world”? George Syncellus' Version of 1Enoch 8:1 in Light of Hesiod's ,, Theogony” and ,, Works and Days”, „Henoch” 34 (2012) 5-20.

\section{Jordanes}

Liebeschuetz W., Why did Jordanes write the Getica?, „Antiquité Tardive” 19 (2011) 295-302.

\section{Julian Apostata}

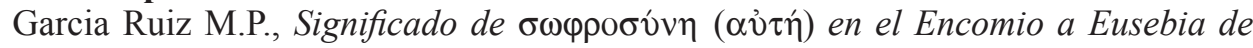
Juliano, „Emérita” 80 (2012) 69-87.

Lagacherie O., Pouvoir et éloquence à la fin de l'Antiquité: le discours contre Héracleios le cynique de l'empereur Julien, „Vita Latina” 183-184 (2011) 193204.

\section{Julian z Eklanum}

Cipriani N., Acerca de las fuentes orientales de la teología de Juliano de Eclana, „Augustinus” 56 (2011) 513-526. 
Cipriani N., Aspectos literarios del „Ad Florum” de Juliano de Eclana, „Augustinus” 57 (2012) 221-262.

Cipriani N., Ecos antiapolinaristas y aristotelismo en la polémica de Juliano de Eclana, „Augustinus” 56 (2011) 269-284.

Cipriani N., El autor de los textos pseudobasilianos reproducidos en C. Iul. 1, 1617, y la polémica antiagustiniana de Juliano de Eclana, „Augustinus” 56 (2011) 285-295.

Cipriani N., La presencia de Teodoro de Mopsuestia en la teología de Juliano de Eclana, „Augustinus” 56 (2011) 297-310.

\section{Julian z Halikarnasu}

Kofsky A., The Miaphysite Monasticism of Gaza and Julian of Halicarnassus, OCP 78 (2012) 81-96.

\section{Juliusz Afrykańczyk}

Bossina L., I „, Cesti” di Giulio Africano, „Adamantius” 18 (2012) 307-316.

\section{Justus z Urgello}

--, Sermo de s. Vincentio (CPL 1092). Estudio de su tradición manuscrita, edición crítica y traducción J.C. Martín - S.I. Abellán, „Anuario de Estudios Medievales” 42 (2012) 229-251.

\section{Justyn}

Bono D., Il Canto del Servo (Is. 53) nell'opera di san Giustino, „Augustinianum” 51 (2011) 315-330.

García Bazán F., Justino de Roma, el primer filósofo católico, TyV 52 (2011) 11-34.

García Bazán F., Testimonios y fuentes del primer filósofo proto-ortodoxo, Justino Mártir, „Studium” 14 (2011) 75-84.

Georges T., Die christlichen Apologeten des 2. Jahrhunderts und ihr Verhältnis zur antiken Philosophie: Justin und Tertullian als Exponenten unterschiedlicher Grundorientierungen?, „Early Christianity” 3 (2012) 321-348.

Ensor P.W., Justin Martyr and penal substitutionary atonement, „, The Evangelical Quarterly" 83 (2011) 217-232.

Félix V.L., La relación entre razón y revelación en la antropología de Justino mártir, TyV 52 (2011) 35-50.

Thorsteinsson R.M., By philosophy alone. Reassessing Justin's Christianity and his turn from Platonism, „Early Christianity” 3 (2012) 492-517.

Thorsteinsson R.M., The literary genre and purpose of Justin's „, Second apology”. A critical review with insights from ancient epistolography, HTR 105 (2012) 91114.

Zañartu S., El testimonio de Justino mártir, „Revista Católica” 111 (2011) 50-52.

\section{Justyn Pseudo-}

Arcari L., Memorie monoteistiche „pagane” nella „Cohortatio ad Graecos” ps.giustinea. L'unicità divina come strumento di auto-definizione elo di attacco, „Auctores Nostri” 9 (2011) 283-315. 
Glede B., Johannes Philoponos und die christliche Apologetik. Die Widerlegungen des Proklos und Aristoteles und die Debatte des Schöpfungsproblems in der Schule von Gaza und bei Ps-Justin, JACh 54 (2011) 73-97.

Simonetti M., In margine allo PseudoGiustino, „Augustinianum” 51 (2011) 5-19.

\section{Juwenkus}

Green R.P., Problems in the text of Juvencus, VigCh 65 (2011) 199-213.

\section{Kasjodor}

Canella T., Tolleranza o intolleranza religiosa?: principi di buon governo e convivenza civile nel dibattito culturale cristiano tardoantico, ASE 28 (2011) 205-239.

Pieroni P., Digressioni nelle ,,Variae” di Cassiodoro: ancora qualche considerazione, „Bollettino di Studi Latini” 41 (2011) 543-555.

\section{Klemens Aleksandryjski}

Calderón Dorda E.A., Clemente de Alejandría y la doctrina astral, „MHNH” 11 (2011) 438-452.

Contreras E., En torno al diálogo de los Padres de la Iglesia con la cultura de su tiempo. Dos aportes significativos de Clemente de Alejandría, „Soleriana” 31-32 (2010-2011) 5-22.

Dainese D., Clemente d'Alessandria e la filosofia. Prospettive aperte e nuove proposte, „Annali di Scienze Religiose” 4 (2011) 223-259.

Havrda M., Grace and free will according to Clement of Alexandria, JECS 19 (2011) 21-48.

Kindiy O., The Christological Notion of Diakonos in Clement of Alexandria, StPatr 51 (2011) 25-43.

Merino Rodríguez M., Razón y fe en Clemente de Alejandría, TyV 52 (2011) 51-92.

Nicklas T., ,Wohin eilen wir?” (Clemens von Alexandrien, Exc. 78,2): Individuelle „Eschatologien” im Denken „gnosticher” Gruppen, „Revista Catalana de Teología" 37 (2012) 67-83.

Rizzi M., The Literary Problem in Clement of Alexandria: a Reconsideration, „Adamantius” 17 (2011) 154-163.

Sedlak R.A., Klemens - ein christlicher Autor in Alexandria, „Biblische Notizen” 2011, nr 148, 101-111.

\section{Klemens Rzymski}

Berding K., Polycarp's use of 1 Clement. An assumption reconsidered, JECS 19 (2011) 127-139.

Downs D.J., Redemptive almsgiving and economic stratification in 2 Clement, JECS 19 (2011) 493-517.

Gil R., Clément de Rome et l'Église. Quels modes de construction identitaire? (1 Clément, 36-44), RevSR 85 (2011) 45-64.

\section{Kolumba}

Maraschi A., I miracoli alimentari di San Colombano: l'originalità, la tradizione e la simbologia, „Studi Medievali” 52 (2011) 517-575. 


\section{Kosmas Vestitor}

Fernández T., Cosmas Vestitor's ascetic-physiological fragment (CPG 8163), ByzZ 104 (2011) 633-640.

\section{Laudes Domini}

Warburg I., Escatología final e intermedia en el poema „Laudes Domini”, SE 50 (2011) 71-86.

\section{Leander z Sewilli}

Gómez Cobo A., Metáforas para la unidad en la Homelia in laude Ecclesiae de Leandro de Sevilla, „Carthaginensia” 27 (2011) 247-273.

\section{Leon I., papiė}

Tyburowski K., Ieiunium and eleemosyna / charitas as Important Elements on the Christian's Way to Perfection according to the Sermons of St Leo the Great, StPatr 51 (2011) 133-147.

Van de Schoor R.J., Canisius als Herausgeber. Die Ausgaben von Tauler (1543), Kyrill (1546) und Leo dem Großen (1546), „Ons Geestelijk Erf” 82 (2011) 161-186.

\section{Leoncjusz z Neapolis}

Cavallero P.A., El léxico bizantino de Leoncio de Neápolis en Vida de Juan el limosnero, „Erytheia” 32 (2011) 139-157.

Fuertes F.J., No sólo negros sino „Etíopes”: la apariencia oscura de los demonios en la „, Vida de Simeón el Loco”, de Leoncio de Neápolis, „Estudios Humanisticos. Historia" 10 (2011) 261-275.

\section{List Barnaby}

Kok M., The true covenant people. Ethic reasoning in the Epistle of Barnabas, „Studies in Religion” 40 (2011) 81-97.

\section{List do Diogneta}

Crowe B.D., Oh sweet exchange!. The soteriological significance of the incarnation in the Epistle to Diognetus, ZNW 102 (2011) 96-109.

Fédou M., Sur l',À Diognète”. Être dans le monde sans être du monde, „Christus” 2011, nr 230, 176-184.

Moser F., La condition chrétienne selon les chapitres V et VI de la „Lettre à Diognète”, „Revue de théologie et de philosophie” 144 (2012) 29-46.

\section{Makary Egipski Pseudo-}

Horyacha M., The Image of the Perfect Christian in the Writings of Pseudo-Macarius, StPatr 51 (2011) 149-170.

Hunt H.M., ,, Working the Earth of the Heart”: Images of Cultivation and Harvest in Macarius and Ephrem, StPatr 52 (2011) 149-160.

Plested M., Macarius and Messalianism: The ,, Status quaestionis”, StPatr 50 (2011) 253-258. 
Maksym Wyznawca

Archimandrite Placide, Le Père Cyprien Kern et saint Maxime le Confesseur, „Le Pensée Orthodoxe" 9 (2012) 67-74.

Berthold G.C., Free Will as a Partner of Nature: Maximus the Confessor on the Our Father, StPatr 51 (2011) 173-179.

Blowers P.M., Maximus the Confessor and John of Damascus on Gnomic Will ( $\gamma v \omega ́ \mu \eta)$ in Christ: Clarity and Ambiguity, „Union Seminary Quarterly Review” 63 (2012) nr 3-4, 44-50.

Ide P., La trilogie patristique de Balthasar (Origène, Grégoire de Nysse et Maxime). Une première ébauche de sa Théologie de l'amour, „Gregorianum” 93 (2012) 711-744.

Pons Pons G., El martirio y la gloria de San Lorenzo en los Sermones de San Agustín y San Máximo, „La Ciudad de Dios” 224 (2011) 283-297.

Seewald M. - Stubenrauch B., Freiheit-ein Modewort der Theologie? Systematische Klärungsversuche im Anschluss an Augustinus und Maximus Confessor, „Communio" 40 (2011) 381-395.

Vercruysse J.M., La mystagogie de Maxime le Confesseur: un itinéraire symbolique et spirituel, CPE 2012, nr 126, 78-90.

Vercruysse J.M., Maxime le Confesseur, CPE 2011, nr 124, 53-59.

\section{Marceli z Ancyry}

Alba Lòpez A., The Reaction against Marcellus of Ancyra in the West $t$, VetCh 48 (2011) 185-205.

Kohaupt B., „Und seiner Herrschaft wird kein Ende sein”. Dogmengeschichtliche Beobachtungen zur Bedeutung der Auseinandersetzungen um Markell von Ankyra, ThG 101 (2011) 265-281.

\section{Marcin z Bragi}

De Miranda J.C.L., ,, Omnia ad usum hominum”. Tipologias cultu(r)ais e ética antropocêntrica no De correctione rusticorum de S. Martinho de Dume, ,Theologica” 47 (2012) 521-540.

\section{Marcin z Tours}

Roch M., "Ce pauvre lui était réservé». L’attention au prochain dans la "Vie de s. Martin de Tours», CPE 2012, nr 127, 47-51.

\section{Mariusz Wiktoryn}

Cipriani N., Agustín lector de los comentarios paulinos de Mario Victorino, „Augustinus” 56 (2011) 425-441.

Cipriani N., La presencia de Mario Victorino en la reflexión trinitaria de san Agustín, „Augustinus” 56 (2011) 459-511.

\section{Maruta z Majperkat}

Molinier J.L., La solidarité chez les moines Perses au début du Vé siècle: le témoignage du «frère chargé de visiter les prisonniers» dans les Canons de Marutha de Maipherqat, CPE 2012, nr 127, 52-60. 


\section{Meliton z Sardes}

Moga I., Interactions between Jews, pagans, and Christians in Sardis in the testimony of Melito, „Classica \& Christiana” 7 (2012) 193-200.

Saez Gutiérrez A., Cristo y la creación de la „Homilía Pascual” de Melitón de Sardes, RET 73 (2012) 55-80.

\section{Metody z Olimpu}

Guignard Ch., Un passage de Méthode d'Olympe parmi des extraits agricoles, „Augustinianum” 52 (2012) 155-158.

\section{Narsai}

Kavvadas N., Narsais homilie „Über die Väter, die Lehrer Diodor von Tarsos, Theodor von Mopsuestia und Nestorios", SE 51 (2012) 215-232.

\section{Nemezjusz z Emezy}

Alejandro R.E., Christology and Hybridity in Nemesius of Emesa, StPatr 52 (2011) 265-274.

\section{Nil z Ancyry}

Ceulemans R., On a Commentary Attributed to Eusebius of Caesarea and Nilus (the Monk / the Anchorite), „Adamantius” 18 (2012) 283-296.

\section{Nonnos z Panapolis}

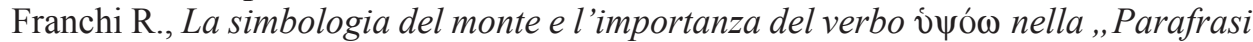
del Vangelo di San Giovanni” di Nonno di Panopoli, „Augustinianum” 51 (2011) 473-499.

\section{Nowacjan}

Simonetti M., A proposito di un recente libro su Novaziano, VetCh 48 (2011) 5-21.

Wallraff M., Heterodoxie und Kirchengeschichte. Der Eunomianismus des Philostorgios und der Novatianismus des Sokrates, OrtF 25 (2011) / 2 201-211.

\section{Optat z Milewy}

Rossi A., De genere iusto. Elementi di propaganda costantiniana nella supplica donatista del 313 (Optat. 1,23,2), VetCh 49 (2012) 117-141.

\section{Orozjusz}

Madonna A., Cultura augustea e matrici cristiane nella rappresentazione orosiana dell'ecumene, „Classica \& Christiana” 7 (2012) 169-182.

Sánchez S.J.G., El priscilianismo, según Orosio, „Augustinus” 57 (2012) 177-192.

\section{Orygenes}

Bastitta Harriet F., La teoría de los principios de la tradición platónica en el pensamiento de Orígenes, „Studium” 14 (2011) 5-18.

Bruns Ch., Hörer des Wortes. Karl Rahner und Origenes, ThPh 87 (2012) 46-72.

Burini de Lorenzi C., Panis quotidianus. Tertulliano e Origene: le due direttrici esegetiche e la loro recezione, „Adamantius” 18 (2012) 178-199. 


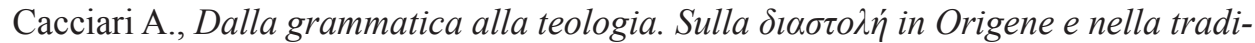
zione origeniana, „Adamantius” 17 (2011) 190-207.

Carrier R.C., Origen, Eusebius, and the accidental interpolation in Josephus: Jewish Antiquities 20.200, JECS 20 (2012) 489-514.

Ciner P., Unidad y Polisemia de la noción de apyn en el „Comentario al Evangelio de Juan" de Orígenes, TyV 52 (2011) 93-104.

Cocchini F., La questione dei cibi (Rm 14) nel „, Commento di Origene alla Lettera ai Romani”, „Adamantius” 18 (2012) 218-225.

Decock P.B., Origen: on making sense of the resurrection as a third century Christian, „Neotestamentica” 45 (2011) 76-91.

DelCogliano M., Origen and Basil of Caesarea on the liar paradox, „Augustinianum” 51 (2011) 349-365.

Di Pasquale Barbanti M., Platone contro Platone nel „Contra Celsum” di Origene. Presupposti storici e strutture teoriche, „Auctores Nostri” 9 (2011) 233-256.

Dorival G., XII Convegno del Gruppo Italiano di Ricerca su Origene e la Tradizione Alessandrina. "I Commenti di Origene ai Salmi: contributi critici e prospettive d'edizione» (Bologna, 10-11 febbraio 2012): Bilan, problèmes, tâches, „Adamantius” 18 (2012) 364-365.

Edwards M.J., Further Reflections on the Platonism of Origen, „Adamantius” 18 (2012) 317-324.

Gemeinhardt P., Schola animarum. Bildung und Religion in der Schule des Origenes, „Biblische Notizen” 2011, nr 148, 113-123.

Grosso M., A new link between Origen and the Gospel of Thomas. Commentary on Matthew 14,14, VigCh 65 (2011) 249-256.

Guly S., The Distinction between propaqeiai and First Voluntary Movements in Origen's „,De principiis” III, StPatr 50 (2011) 177-188.

Heine R.E., Origen and a hermeneutic for spirituality, „Stone-Campbell Journal” 14 (2011) 67-79.

Hengstermann Ch., Origen in Early Modern Cambridge: A Conference on the Cambridge Origenists and George Rust's Letter of Resolution Concerning Origen and the Chief of his Opinions, „Adamantius” 17 (2011) 303-316.

Holliday L.R., From Alexandria to Caesarea. Reassessing Origen's appointment to the Presbyterate, „Numen” 58 (2011) 674-696.

Ide P., La trilogie patristique de Balthasar (Origène, Grégoire de Nysse et Maxime). Une première ébauche de sa Théologie de l'amour, „Gregorianum” 93 (2012) 711-744.

Lago J.F., La Iglesia de los Gentiles en HomNum y HomJos de Orígenes, „Compostellanum” 56 (2011) 187-215.

Linebaugh J.A., Rational or Radical: Origen on Romans 9:10-4, StPatr 52 (2011) 63-69.

Martens P.W., Origen Against History?: Reconsidering the Critique of Allegory, „Modern Theology” 28 (2012) 635-656.

Muraru A., Strategies of Translation in Late Antiquity. Rufinus and the Bilingual Readers of Origen's ,Homilia in Exodum” 9, „Adamantius” 17 (2011) 297-302.

Pazzini D., Origeniana Nona: Origen and the Religious Practice of His Time, „Adamantius” 17 (2011) 317-337.

Pazzini D., Origeniana Decima: Origen as Writer, „Adamantius” 18 (2012) 336-363. 
Possekel U., Bardaisan and Origen on Fate and the Power of the Stars, JECS 20 (2012) 515-541.

Radde-Gallwitz A., The Holy Spirit as agent, not activity. Origen's argument with modalism and its afterlife in Didymus, Eunomius, and Gregory of Nazianzus, VigCh 65 (2011) 227-248.

Ramelli I.L.E., Atticus and Origen on the soul of God the creator. From the pagan to the Christian side of middle Platonism, „Jahrbuch für Religionsphilosophie” 10 (2011) 13-35.

Ramelli I.L.E., Origen, Greek philosophy, and the birth of the trinitarian meaning of hypostasis, HTR 105 (2012) 302-350.

Ramelli I.L.E., Origen's anti-subordinationism and its heritage in the Nicene and Cappadocian line, VigCh 65 (2011) 21-49.

Ramelli I.L.E., The Dialogue of Adamantius: A Document of Origen's Thought? (Part One), StPatr 52 (2011) 71-98.

Rapetti E., "Res Origenis referre»: gli Origeniana di Pierre-Daniel Huet e il loro contesto storico-culturale, „Adamantius” 18 (2012) 251-282.

Rizzi M., La rinascità dell'apocatastasi, ovvero tre modi per leggere Origene oggi, SD 57 (2012) 33-45.

Shuve K., Origen and the „Tractatus de Epithalamio” of Gregory of Elvira, StPatr 50 (2011) 189-203.

Simonetti M., Qualche novità sulla dottrina origeniana del Logos, „Augustinianum” 51 (2011) 331-348.

Simonetti M., Su Origene, „Commento a Matteo” 15, 10-19, „Augustinianum” 52 (2012) 107-133.

Somos R., Strategy of Argumentation in Origen's „Contra Celsum”, „Adamantius” 18 (2012) 200-217.

Tampellini S., Le „Omelie su Luca” da Origene a Gerolamo (e Ambrogio): considerazioni introduttive, „Adamantius” 18 (2012) 226-232.

Trostyanskiy S., Reading Origen of Alexandria from the Perspective of Contemporary Semantics, „Union Seminary Quarterly Review” 63 (2012) nr 3-4, 34-43.

Vakula O., Spiritual Progress and a Disciple of Christ as a Model of the Perfect Christian in Origen, StPatr 51 (2011) 45-59.

Villani A., Il posto della retorica nella strategia polemica di Origene contro Celso, „Auctores Nostri” 9 (2011) 257-281.

Villani A., Homer in the debate between Celsus and Origen, REAug 58 (2012) 113-139.

Zañartu S., Primogénito de toda creatura $(\mathrm{Col} 1,15)$ en el „Comentario de Orígenes al Evangelio de Juan”, TyV 52 (2011) 105-152.

\section{Pachomiusz}

Förster H., Trat um das Jahr 328 ein unmündiges Kind entgegen dem elterlichen Willen in das Kloster des Pachomius ein?: juristische Probleme in einer ägyptischen Mönchsvita, „Zeitschrift der Savigny-Stiftung für Rechtsgeschichte. Kanonistische Abteilung" 128 (2011) 1-19.

\section{Papiasz}

Bernier J., From Papias to Hegesippus: on the production of Christian institutional memory, „Theoforum” 42 (2011) 37-46. 
Hegedus T., Midrash and Papias of Hierapolis, „Biblical Theology Bulletin” 42 (2012) 30-35.

Lur'e G., An unknown Danielic pseudepigraphon from an Armenian fragment of Papias, „Journal for the Study of the Pseudepigrapha” 21 (2012) 323-339.

\section{Patryk}

Bonner A., Was Patrick influenced by the teaching of Pelagius?, JTS 63 (2012) 572-607. Iannello F., Il modello paolino nell',,Epistola ad milites Corotici” di san Patrizio, „Bollettino di Studi Latini” 42 (2012) 43-63.

\section{Paulin z Mediolanu}

Navoni M., Ibarbari nella ,,Vita Ambrosii” di Paolino da Milano, „Studia Ambrosiana” 5 (2011) 169-192.

\section{Paulin z Noli}

Amherdt D., Paulin de Nole rhéteur chrétien : le miracle de la parole, CPE 2011, nr 123, 27-38.

De La Portbarre-Viard G.H., Les descriptions du complexe basilical dédié À S. Félix dans l'œuvre de Paulin de Nole: leur rôle dans l'évolution de l'art paléochrétien et ses représentations littéraires, CPE 2011, nr 123, 39-49.

Desmulliez J., Paulin de Nole: du gouverneur de Campanie à l'évêque de Nole, CPE 2011, nr 123, 2-13.

Vanhems C., Paulin ou l'invention d'un style chrétien, CPE 2011, nr 123, 14-26.

Vercruysse J.M., Le chrétien face à la mort d'après Paulin de Nole (Epistula 13 et Carmen 31), CPE 2011, nr 123, 50-60.

\section{Paulin z Périgueux}

Labarre S., La transmission de Paulin de Périgueux: les principes d'une nouvelle édition, „Revue d'Histoire des Textes” 7 (2012) 117-158.

\section{Pelagiusz}

Bonner A., Was Patrick influenced by the teaching of Pelagius?, JTS 63 (2012) 572-607.

Cipriani N., La moral pelagiana y la retórica, „Augustinus” 57 (2012) 263-279.

Dupont A., Lectura del comentario de Pelagio a la carta de Pablo a los Romanos, „Augustinus” 57 (2012) 49-73.

Ogliari D., Tra teologia e ascesi. Aspetti salienti del pensiero di Pelagio, „Euntes Docete" 65 (2012) 189-216.

Toczko R., Heretic as bad rhetorician: how Augustine discredited Pelagius, „Augustinian Studies” 42 (2011) 211-231.

Piotr Iberyjezyk

Parvis P., How to Lynch a Patriarch Without Really Trying: Peter the Iberian and the Ambiguities of Late Antique Sanctity, StPatr 52 (2011) 305-317.

\section{Polikarp ze Smyrny}

Berding K., Polycarp's use of 1 Clement. An assumption reconsidered, JECS 19 (2011) 127-139. 
Lai P.W., Dialogue and Ideology in the „Martyrdom of Polycarp”: a Bakhtinian Analysis, StPatr 52 (2011) 37-45.

Kozlowski J.M., Polycarp as a Christian Gymnosophist, StPatr 51 (2011) 15-22.

Selby A.M., Bishops, elders, and deacons in the Philippian church. Evidence of plurality from Paul and Polycarp, „Perspectives in religious studies” 39 (2012) 79-94.

\section{Porfiriusz}

--, Sentences. Études d'introduction, texte grec et traduction française, commentair G. Karamanolis, ,The International Journal of the Platonic Tradition” 5 (2011) 159-164.

Yudin V., Porphyry against the Resurrection in Augustine, StPatr 50 (2011) 301-307.

\section{Proba}

Cabezas Cabello M.J., El rostro de Dios en el poema de Proba, „Isidorianum” 21 (2012) 459-472.

\section{Prokopiusz z Cezarei}

Amitay O., Procopius of Caesarea and the Girgashite diaspora, „Journal for the Study of the Pseudepigrapha" 20 (2011) 257-276.

Cherf W., Procopius' ,'De aedificiis” 4.2.122 and the Oite-Kallidhromos frontier barrier, ByzZ 104 (2011) 71-113.

\section{Prosper z Akwitanii}

Cutino M., L'auteur du „De providentia Dei” et un mystérieux calomniateur d'Augustin: pour une interprétation de deux épigrammes polémiques de Prosper d'Aquitaine, RevSR 86 (2012) 307-342.

Chan S., The use of Prosper's rule in the development of Pentecostal ecclesiology, „International Journal for the Study of the Christian Church” 11 (2011) 305-317.

\section{Prudencjusz}

Bilby M.G., Christendom witnesses to the martyrs. Modulations of the „Acta Martyrum” in Prudentius ', Peristephanon” VI, JEH 63 (2012) 219-235.

Clarke J.R., Landscapes of the body in Prudentius „,Cathemerinon” VII, VigCh 66 (2012) 379-397.

D’Auria I., La prosopopea di Roma nel „Contra Symmachum” di Prudenzio, „Auctores Nostri” 9 (2011) 427-456.

Dorfbauer L. J., Claudian und Prudentius: Verbale Parallelen und Datierungsfragen, „Hermes” 140 (2012) 45-70.

Gärtner Th., Echtheitskritische Überlegungen zur Praefatio von Prudenzens Gesamtwerk, ZACh 15 (2011) 322-328.

Gnilka Ch., Römische Verfassungsgeschichte bei Prudentius und Ampelius, „Hermes” 140 (2012) 448-456.

Guttilla G., Una lettura del „Peristephanon 6” di Prudenzio tra Trinità „teologica”, trinità ,,imperiale”, e trinità ,,martiriale”, JECS 19 (2011) 101-126.

Romano P., Il rapporto tra cultura pagana e cristiana nell'opera di Prudenzio, „Rivista di Cultura Classica e Medioevale” 53 (2011) 263-284.

Summers K.M., Prudentius „Psychomachia” 317, VigCh 66 (2012) 426-429. 


\section{Pryscylian}

Sanchez S.J., Priscillien et la culture antique. Étude des „,potestates ventorum”, RBen 121 (2011) 5-17.

Sfameni Gasparro G., Sacramentum regis bonum est abscondere (Agostino, „Epist.” 237, 4): misteri della Scrittura, vera scienza spirituale e dissimulatio in Priscilliano e nel Priscillianesimo, „Annali di Scienze Religiose” 4 (2011) 111-155.

\section{Regula Mistrza}

De Vogüé A., The „, Rule of the Master” and the „Rule” of Saint Benedict in relation to the first monasteries of Subiaco, ABR 63 (2012) 36-48.

Standaert B., Saint Benoît et le Maître: à la recherche du rapport spirituel entre les deux, CCist 73 (2011) 321-334.

\section{Roman Melodos}

Arentzen Th., Hør hvajeg er, forjeg er den du ser!: Maria-fremstillinger $i$ «,, Akathistoshymnen” og Romanos', Bebudelsehymne”, «Svensk Teologisk Kvartalskrift» 87 (2011) nr 4, 162-168.

Pons Pons G., La infancia del Salvador en los himnos de Romano el Cantor: la misión de la Virgen María y de San José, „Estudios Josefinos” 66 (2012) 205-236.

Prelipcean A., Sfântul Roman Melodul - imnograful desăvârşit al Ortodoxiei, ,Studi Teologice" 2011, nr 2, 59-105.

\section{Rufin z Akwilei}

Thelamon F., Présence du monachisme dans l',Histoire ecclésiastique” de Rufin d'Aquilée, ,Adamantius” 17 (2011) 23-38.

\section{Rufin z Akwilei Pseudo-}

Dunphy W., Ps-Rufinus (the ,Syrian”) and the Vulgate: evidence wanting!, „Augustinianum” 52 (2012) 219-256.

\section{Sewer z Antiochii}

Allen P., Severus of Antioch as theologian, dogmatician, pastor, and hymnographer: a consideration of his work on the feast of the Ascension, „Questions Liturgiques” 92 (2011) 361-375.

Smelova N., Palaeography and textual study of some estrangelo manuscripts in St. Petersburg, ParOr 36 (2011) 453-467.

\section{Sewerian z Gabali}

Torresi L., La controversia anti-apollinarista in Severiano di Gabala, „Augustinianum” 52 (2012) 417-439.

\section{Sokrates Scholastyk}

Martin A., D'Eusèbe à Sozomène: la place du monachisme dans les nouvelles „Histoires ecclésiastiques”, „Adamantius” 17 (2011) 93-117.

Wallraff M., Heterodoxie und Kirchengeschichte. Der Eunomianismus des Philostorgios und der Novatianismus des Sokrates, OrtF 25 (2011) / 201-211. 


\section{Sozomen Hermiasz}

Berardi C.C., Polemica antipagana e motivi miracolosi in Sozomeno: alcune riflessioni, „Auctores Nostri” 9 (2011) 333-340.

Martin A., D’Eusèbe à Sozomène: la place du monachisme dans les nouvelles „Histoires ecclésiastiques”, „Adamantius” 17 (2011) 93-117.

Quiroga Puertas A.J., Ghosts Stories in Sozomen's „Ecclesiastical History”, „MHNH” 11 (2011) 385-398.

\section{Sulpicjusz Sewer}

Roch M., "Ce pauvre lui était réservé». L’attention au prochain dans la "Vie de s. Martin de Tours», CPE 2012, nr 127, 47-51.

\section{Sydoniusz Apolinary}

Henke R., Der Brief 3, 12 des Sidonius Apollinaris an Secundus: eine Novelle in einer Epistel?, „Hermes” 140 (2012) 121-125.

Mascoli P., Tracce di Persio in Sidonio Apollinare, „Classica \& Christiana” 7 (2012) 183-192.

Neri M., Sidonio Apollinare (epist. 9,9,10) e la possibile attribuzione del „, De ratione fidei” a Fausto di Riez, „Bollettino di Studi Latini” 41 (2011) 531-542.

Santelia S., L'aristocrazia galloromana celebra se stessa: l'epitalamio per Ruricio ed Iberia (Sidon. Apoll. carm. 11), „Bollettino di Studi Latini” 41 (2011) 103-114.

Van Waarden J., Sidonio Apollinare, poeta e vescovo, VetCh 48 (2011) 99-113.

\section{Symeon Nowy Teolog}

Bekos J., The Ethics of Organ Donation: Insights from St Symeon the New Theologian?, StPatr 52 (2011) 3-8.

Sperlea O., Syméon le Nouveau Théologien comme témoin de la tradition spirituelle de Grégoire de Nysse, SMon 54 (2012) 235-252.

\section{Tacjan Syryjczyk}

Baarda T., Mk 1:41: orgistheis. A reading attested for Mar Ephraem, the „Diatessaron”, or Tatian, ZNW 103 (2012) 291-295.

Löss1 J., Sprachlich-ästhetische Darstellung und „Anwendung”von Gewalt in Texten frühchristlicher Apologeten. Das Beispiel der Rede Tatians an die Griechen, „Zeitschrift für Religionswissenschaft” 20 (2012) 196-222.

Stori E., Vangelo di Tommaso e „Diatessaron”: traiettorie parallele. Il „Diatessaron” e i problemi della ricerca, „Adamantius” 18 (2012) 151-177.

\section{Teodor Studyta}

Cattoi Th., Salvific Asymmetry: Anhypostasy and Icon Veneration in Theodore the Studite's „Antirrhetici”, StPatr 51 (2011) 181-194.

\section{Teodor z Mopsuestii}

Cipriani N., La presencia de Teodoro de Mopsuestia en la teología de Juliano de Eclana, „Augustinus” 56 (2011) 297-310.

Kavvadas N., Theodor von Mopsuestia zur Kanonizität des Hoheliedes, StPatr 52 (2011) 275- 
Pasquet C., Théodore de Mopsueste, CPE 2011, nr 124, 36-41.

\section{Teodoret z Cyru}

Ceulemans R., New Manuscripts of the catena Trium Patrum ('B2') and of the Commentaries by Theodoret of Cyrrhus and the Three Fathers ('B1') on the Song of Songs, JÖB 61 (2011) 105-120.

Giancarli L., La questione della canonicità del Cantico dei Cantici nella prefazione al commento di Teodoreto di Cirro, „Augustinianum” 52 (2012) 353-381.

Giancarli L., Sulla data di composizione del commento al Cantico dei Cantici di Teodoreto di Cirro, VetCh 48 (2011) 261-171.

Puech V., Le réseau politique d'un évêque de l'Antiquité tardive: les correspondants laïcs de Théodoret de Cyr (393-vers 460), „Antiquité Tardive” 19 (2011) 283-294.

\section{Teofanes z Nicei}

Makarov D., Some Notes on the Notions of Synergy and Interpenetration in Theophanes of Nicaea, StPatr 51 (2011) 205-216.

\section{Teofil Aleksandryjski Pseudo}

Suciu A., Sermo de cruce et latrone (CPG 2622). Edition of Pierpont Morgan M595 with parallels and translation., ZACh 16 (2012) 181-225.

\section{Teofil z Antiochii}

De los Santos Granados L., Aportaciones filosóficas de Filón, san Teófilo y san Ireneo al concepto de pecado original, „Anuario de Historia de la Iglesia” 21 (2012) 511-519.

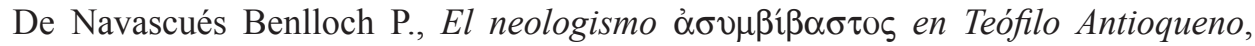
„Augustinianum” 52 (2012) 459-461.

Gili L., Teofilo d'Antiochia, ,,Ad Autolycum” 1, 4, „Augustinianum” 52 (2012) 463-465.

Russell N., Theophilus of Alexandria as a Forensic Practitioner, StPatr 50 (2011) 235-243.

\section{Tertulian}

Burini de Lorenzi C., Panis quotidianus. Tertulliano e Origene: le due direttrici esegetiche e la loro recezione, „Adamantius” 18 (2012) 178-199.

Chronica Tertullianea et Cyprianea 2010., REAug 57 (2011) 375-427.

Cipriani N., La inspiración tertuliana en el „De libero arbitrio” de san Agustín, „Augustinus” 56 (2011) 369-383.

Georges T., Das Gemeindemahl bei Tertullian in „Apologeticum” 39 - eine nichtsakramentale Agapefeier?, ZACh 16 (2012) 279-291.

Georges T., Die christlichen Apologeten des 2. Jahrhunderts und ihr Verhältnis zur antiken Philosophie: Justin und Tertullian als Exponenten unterschiedlicher Grundorientierungen?, „Early Christianity” 3 (2012) 321-348.

Georges T., Religio atque pietas Christiana in imperatorem. Die Ergebenheit der Christen gegenüber der kaiserlichen maiestas gemäß Tertullians ,,Apologeticum”, „Biblische Notizen” 2012, nr 155 131-143.

Gil-Tamayo J.A., La unidad trinitaria como fundamento de la unidad eclesial en Tertuliano y Cipriano de Cartago, ScT 43 (2011) 9-29. 
Gonzalez Salinero R., Apologetica antijudia y „Ecclesia potens” en Tertuliano y Cipriano, „Polis” 23 (2011) 35-59.

Heyne T., Tertullian and Medicine, StPatr 50 (2011) 131-174.

López Montero R., La recepción de Heráclito en Tertuliano de Cartago, „Revista Española de Teología” 71 (2011) 147-165.

Montero R.L., La recepción de Heráclito en Tertuliano de Cartago, RET 71 (2011) 147-166.

Montero R.L., Las referencias a Homero en las obras de Tertuliano, „Augustinianum” 52 (2012) 135-153.

Rizzi M., Rectum quodcunque primum: la regola di Tertulliano in Melantone e nella controversistica del XVI secolo, „Auctores Nostri” 9 (2011) 727-742.

Seewald M., Das „,Filioque” - gedeutet als christologisches Axiom. Ein Versuch zur ökumenischen Verständigung ausgehend von Tertullians „Adversus Praxean”, MThZ 62 (2011) 303-328.

Siat J., Homme de chair pour la gloire de Dieu, dans l'œuvre de Tertullien, CPE 2012, nr 128, 28-38.

Urciuoli E., ,,Factio christiana”. Nouvel examen du rapport entre les premiers groupes de croyants en Christ et les associations volontaires antiques, „Apocrypha” 22 (2011) 253-264.

\section{Testament Pana naszego Jezusa Chrystusa}

Corcoran. S. - Salway B., A newly identified Greek fragment of the „Testamentum Domini", JTS 62 (2011) 118-135.

Stewart-Sykes A., The apocalyptic section of ,, Testamentum Domini”. An attempt at dating, JTS 62 (2011) 136-143.

\section{Wincenty z Lerynu}

Fiedrowicz M., Konzilshermeneutik. Ein Beitrag des Vinzenz von Lérins, „Una-VoceKorrespondenz" 41 (2011) 127-134. 